A plataforma rodoviária de Brasília: infraestrutura, arquitetura e urbanidade.

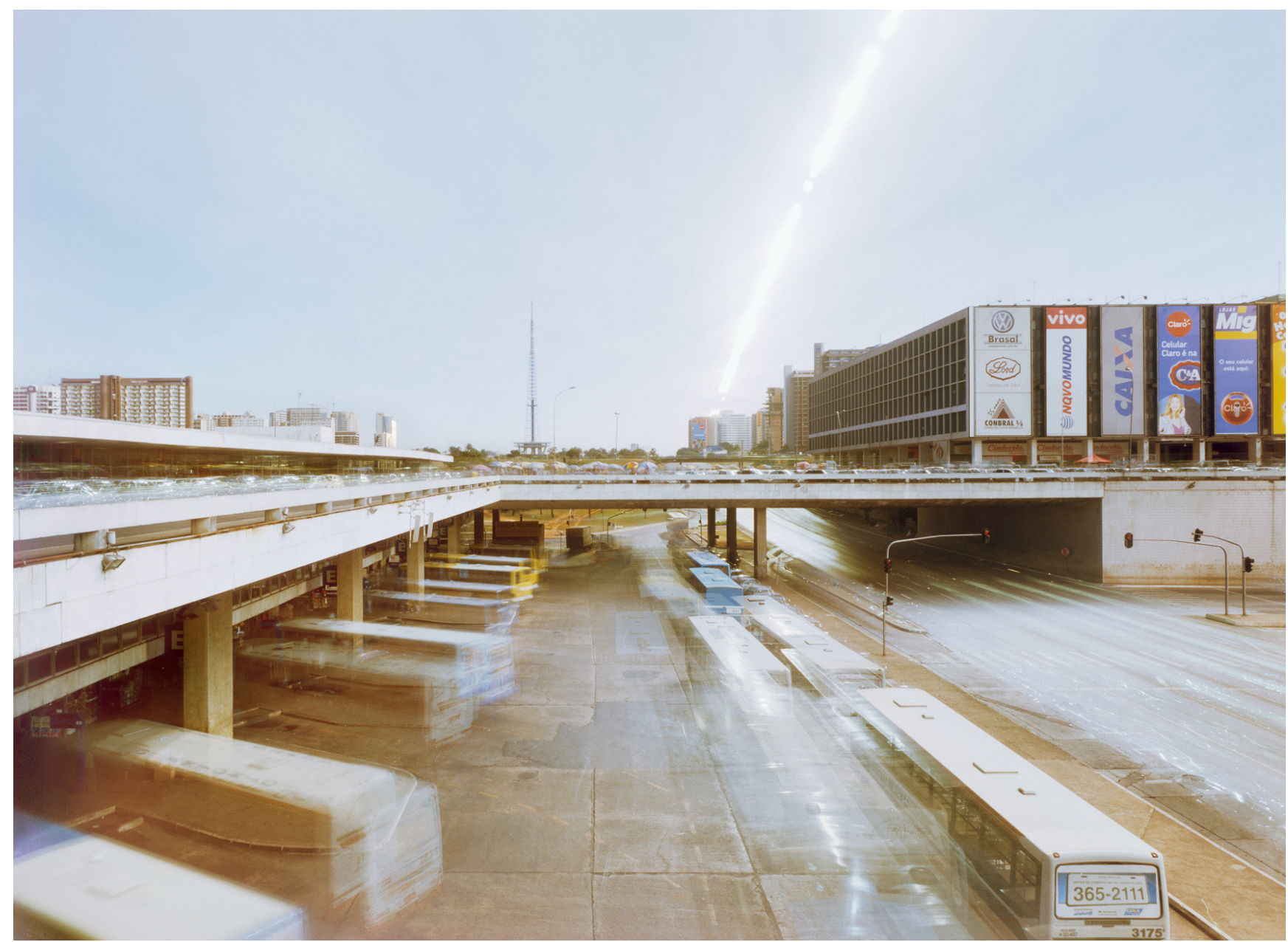

Martin Corullon

dissertação de mestrado

faculdade de arquitetura e urbanismo da universidade de são paulo orientadora: Prof. Dra. Regina Prosperi Meyer 
Autorizo a reprodução e divulgação total ou parcial deste trabalho, por qualquer meio convencional ou eletrônico, para fins de estudo e pesquisa, desde que citada a fonte.

e-mail: mcorullon@gmail.com

Exemplar revisado e alterado em relação à versão original, sob responsabilidade do autor e anuência do orientador. O original se encontra disponível na sede do programa São paulo 20 de julho de 2013

Corullon, Martin Gonzalo

C831 A plataforma rodoviária de Brasília : infraestrutura, arquitetura e urbanidade / Martin Gonzalo Corullon. - São Paulo, 2013.

151 p. : il.

Dissertação (Mestrado - Área de Concentração: Projeto, Espaço e Cultura) - FAUUSP.

Orientadora: Regina Maria Prosperi Meyer

1. Desenho urbano 2. Infraestrutura urbana

3. Cidades 4. Costa, Lucio, 1902-1998 I.Título

CDU 711.6 
A plataforma rodoviária de Brasília: infraestrutura, arquitetura e urbanidade.

\section{Martin Corullon}

dissertação de mestrado apresentada à Faculdade de Arquitetura e Urbanismo da Universidade de São Paulo, na área de concentração Projeto, Espaço e Cultura, sob orientação de:

Prof. Dra. Regina Prosperi Meyer

São Paulo, Março de 2013. 


\section{resumo}

Esta dissertação procura, a partir do estudo da plataforma rodoviária de Brasília projetada pelo arquiteto e urbanista Lucio Costa, discutir questões acerca das relações entre infraestrutura, arquitetura e a cidade. A plataforma rodoviária é um exemplo privilegiado de edificação em que se confundem o edifício arquitetônico e o sistema infraestrutural, e em que é possível avaliar o papel do desenho na produção de urbanidade, entendida como gradação da intensidade de interações entre pessoas e coisas em um determinado ambiente. A análise empreendida parte de uma abordagem ancorada na prática arquitetônica, afastando-se de leituras sociológicas, psicológicas ou puramente formais. São os aspectos materiais, descritos em detalhe, que permitem identificar a "intenção" da construção como simultaneamente articuladora das áreas centrais do Plano Piloto e como estação rodoviária da capital do país.

A partir de material iconográfico, são examinados o projeto original, as diferenças em relação ao projeto construído e desempenho do edifício hoje. Esta análise permite evidenciar problemas na construção, apontar para reformulações futuras, bem como reconhecer as virtudes do projeto em seu potencial de produção de urbanidade.

Palavras-chave: infraestrutura, arquitetura, desenho, urbanidade, Brasília, Lucio Costa 


\section{abstract}

From the study of the central platform of Brasilia, bus station and center of the city life at once, this dissertation seeks to discuss issues concerning the relationships between infrastructure, architecture and the city. Designed by the architect and urban planner Lucio Costa, author of Brasilia's urban plan, the platform is an example of building that blurs architecture and infrastructural system, and allows to investigate the role of design in the production of urbanity, understood as gradation of intensity of interactions between people and things in a certain environment. The analysis approach undertaken is rooted in architectural practice, away from sociological, psychological or purely formal readings of the urban facts. Materiality is described, identifying the "intentions" of a building that simultaneously articulates the central areas of Brasilia and acts as a metropolitan bus station for the capital of the country.

Based on an iconographic research, the original design is examined, the differences regarding the design and as built and the performance of the building today. This analysis allows us to highlight problems in construction, point to future reformulations and acknowledge the virtues of the project in the production of potential of urbanity.

Keywords: infrastructure, architecture, urbanity, Brasília, Lucio Costa 


\section{agradecimentos}

À Regina Meyer, um agradecimento especial. Aos amigos e professores Fernando de Mello Franco e Luís Antônio Jorge, pela leitura e incentivo. Ao Guilherme Wisnik, pela amizade e livros compartilhados. Ao Milton Braga, pela ajuda e ouvido. Aos amigos e grandes fotógrafos Leonardo Finotti e Nelson Kon, com suas imagens fundamentais. E ao Michael Wesely, pela foto da capa. À Sophia Telles, companheira de viagem, pelo estímulo. Ao Gustavo Cedroni, Anna Ferrari e aos amigos da METRO Arquitetos, em especial ao Rafael de Souza e à Marina loshii, pela paciência. Às meninas Malu e Viola e à Flor, por tudo. 
índice

introdução

capítulo 1 - Infraestrutura, arquitetura e urbanidade

capítulo 2 - a plataforma rodoviária hoje

capítulo 3 - a plataforma rodoviária no tempo

conclusão

bibliografia 


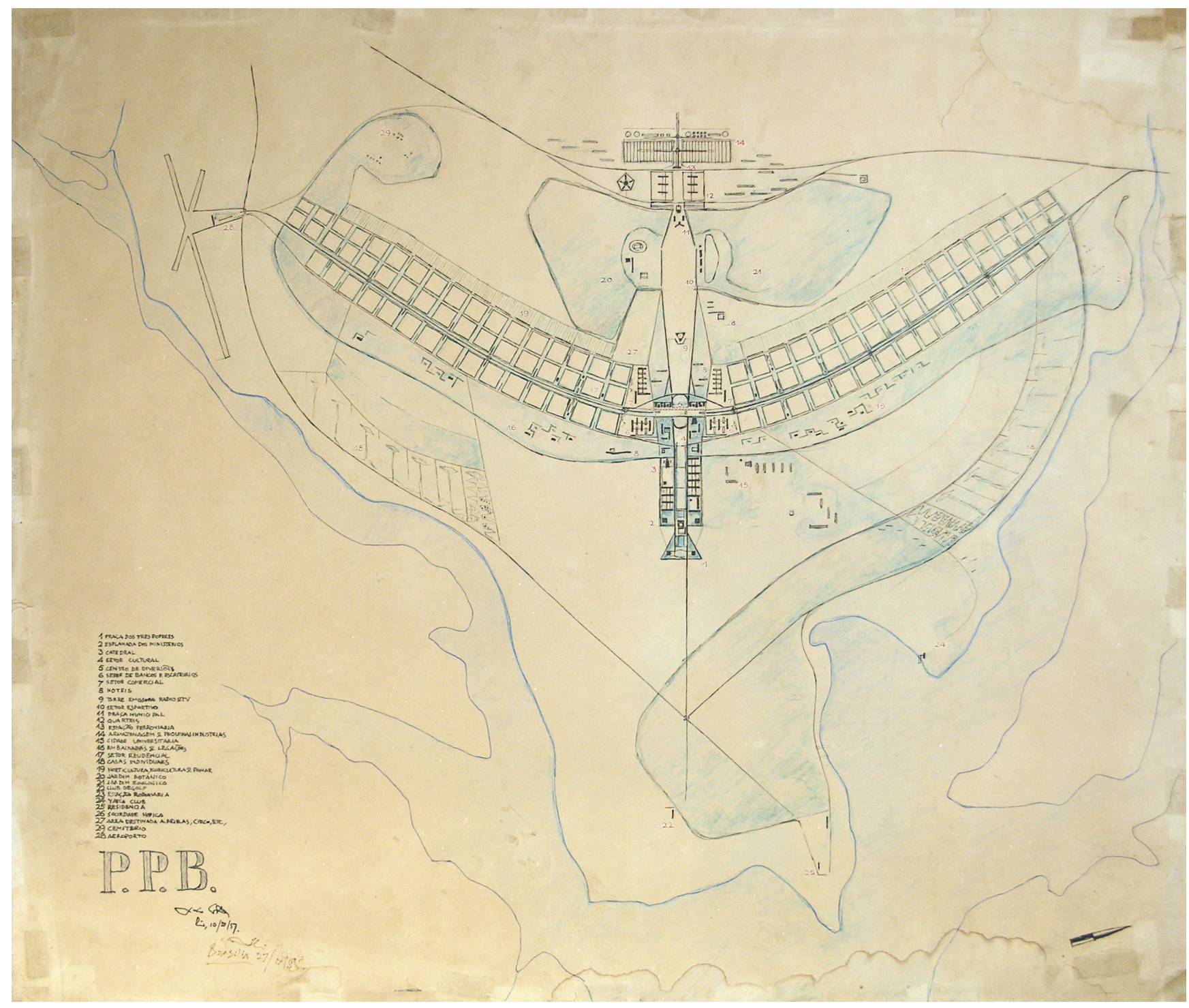

fig. 1 - Planta Geral do Plano Piloto de Brasília, apresentada por Lucio Costa ao júri do concurso, em 1957. Fonte: Acervo Casa de Lucio Costa. 


\section{introdução}

Esta dissertação procura, a partir da análise da plataforma rodoviária de Brasília projetada pelo arquiteto e urbanista Lucio Costa, levantar questões acerca de um campo de discussão vasto: o da relação entre edifício arquitetônico, infraestrutura e a cidade. Cabe perguntar, de início, se é mais apropriado definir a plataforma como um edifício ou como uma obra de infraestrutura. A questão se desdobra em outras: Quais são os limites entre arquitetura e desenho urbano? Qual o papel das redes infraestruturais na definição da forma da cidade? Qual é a influência ou o potencial dessas redes infraestruturais e seus pontos de articulação no grau de urbanidade de uma cidade? É sob o prisma desse conjunto de questões que a plataforma rodoviária de Brasília será examinada ao longo desta dissertação.

A investigação sobre as condições e características que permitem à plataforma rodoviária desempenhar um papel simultaneamente de nó infraestrutural e de espaço de socialidade e articulação do centro de Brasília foi dividida nesta dissertação em três partes:

No primeiro capítulo é feita uma discussão dos conceitos de urbanidade e as concepções de infraestrutura e arquitetura que norteiam a análise da plataforma.

No segundo capítulo, realiza-se uma análise do funcionamento da plataforma hoje. Através do levantamento do desenho atual do edifício, seus usos, virtudes e deficiências, é possível fazer um diagnóstico do efetivo grau de articulação e urbanidade que ela desempenha. Nesse capítulo o edifício é observado em seu estado atual, tanto em seus aspectos formais como funcionais. A partir dos desenhos e levantamentos 

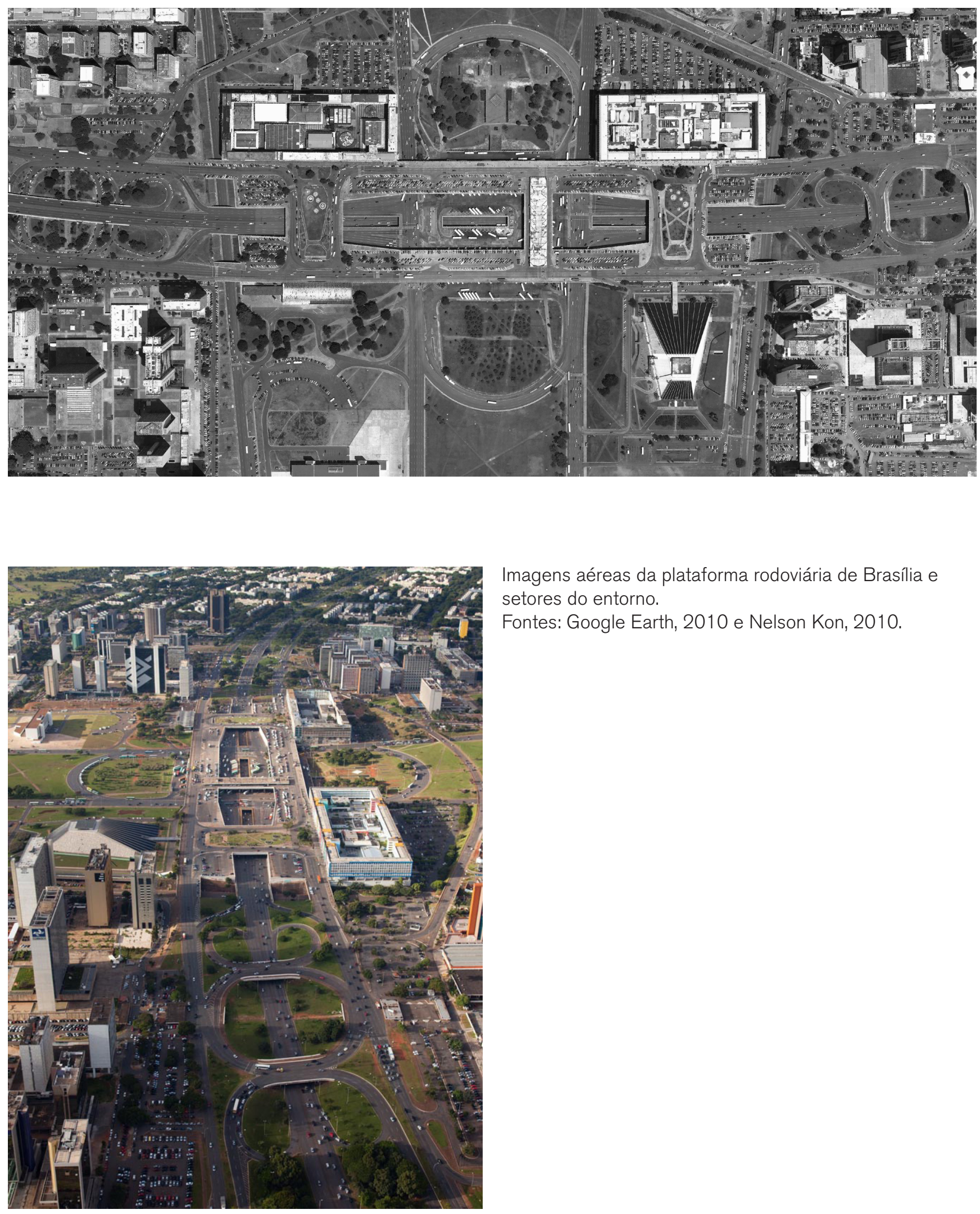

Imagens aéreas da plataforma rodoviária de Brasília e setores do entorno.

Fontes: Google Earth, 2010 e Nelson Kon, 2010. 
atualizados, são descritos e analisados os espaços que conformam a plataforma, em sua materialidade. Soma-se ainda uma descrição de seu funcionamento como nó articulador da rede de transportes públicos de Brasília, e como estrutura articuladora dos espaços públicos que a constituem e que a circundam - os centros de compras Conic e Conjunto Nacional e o Teatro Nacional.

A intenção é avaliar o funcionamento da plataforma rodoviária de Brasília e poder aferir de que modo ela, efetivamente, desempenha as funções definidas pelo projeto em 1957. Ou seja, busca-se entender qual é a sua participação e desempenho como peça de infraestrutura urbana integrante do sistema de transportes da metrópole e, simultaneamente, qual o tipo e intensidade de vida urbana propicia e como esta se realiza em seus espaços.

No terceiro capítulo, a análise é centrada no projeto e construção da plataforma e aborda-se a história do edifício desde sua concepção até a configuração atual. A pesquisa aborda as transformações do edifício, analisando desde os primeiros croquis e intenções, às mudanças durante o detalhamento do projeto e apropriação dos espaços e sucessivas transformações propostas ou realizadas após sua inauguração, e incorpora registros fotográficos realizados ao longo do período estudado.

É realizada uma leitura das intenções do projeto, conexões e funcionamento imaginados, e uma comparação com o que foi efetivamente construído, seus limites e os usos imprevistos. Também é feito um levantamento de suas potencialidades de transformação futura, como forma de intervir em uma zona de Brasília ainda não plenamente consolidada.

A conclusão busca apontar para as potencialidades dos dispositivos geradores de urbanidade identificados e como estes se materializam, na plataforma rodoviária e em outros projetos em escala similar, de forma a interferir positivamente no meio em que se inserem. As breves comparações com projetos de mesma natureza, ocorridos em diversas épocas e lugares também dão uma medida da relevância das questões por eles compartilhadas e do lugar do projeto da plataforma em uma perspectiva 
histórica ampla. Também aponta-se a conexão do projeto e suas intenções com teorizações contemporâneas acerca de novos arranjos disciplinares no enfrentamento das questões urbanas atuais, em que se reivindica a eficácia do desenho como forma de atuação, em práticas que diluem fronteiras disciplinares entre arquitetura, paisagismo e urbanismo. 
Capítulo 1 - Infraestrutura, arquitetura e urbanidade 


\section{Infraestrutura, arquitetura e urbanidade}

O fato de ser uma peça importante do Plano Piloto de Brasília, projeto chave da história da arquitetura e urbanismo brasileiros, coloca a este trabalho de análise e pesquisa um dilema: se por um lado se beneficia do acesso a uma grande produção crítica e documental, por outro, corre o risco de repisar informações e interpretações conhecidas do leitor. No entanto, mesmo com um grande conjunto de publicações recentes, motivadas pelo cinquentenário da inauguração de Brasília, chama a atenção não haver uma produção acadêmica constituída (dissertações de mestrado, teses de doutorado, artigos em revistas acadêmicas) especificamente voltada para a análise da plataforma rodoviária. A maior parte das referências se compõe de apresentações em congressos ou exercícios didáticos.

Há muitas formas de abordar um fato urbano. Os fenômenos ou condições urbanas avaliados aqui, são apreendidos por instrumentos da percepção e da experiência próprias de um arquiteto de ofício, com a dimensão material implicada nesse tipo de aproximação. Não são portanto observações baseadas em análises com ênfase sociológica, comportamental ou psicológica. Tampouco trata-se de uma abordagem que analisa a produção do espaço como resultado de processos econômicos, ou que reivindica um papel protagonista à História, ou ainda, análises que atribuem valor narrativo à imagem da cidade ou aproximações apenas morfológicas.

A abordagem que empreendo aqui está intrinsecamente relacionada a minha prática como arquiteto. $\mathrm{O}$ conhecimento que busco produzir acerca da plataforma é resultado de uma visão operativa do espaço material- 
mente constituído. Essa abordagem se assemelha à descrita por Stan Allen em "Infrastructural Urbanism". Nesse artigo, o autor defende a arquitetura e o urbanismo como uma prática iminentemente material, "como atividade que opera no e entre o mundo das coisas ${ }^{1}$. e não exclusivamente com significados ou imagens", reivindicando sua instrumentalidade e um afastamento da noção de representação. A descrição que farei da plataforma parte do suposto que ela é capaz de exercer agência ${ }^{2}$ isto é, ela produz ações e relações entre humanos e coisas em função de suas características. Buscarei portanto descrever as características materiais da plataforma, bem como os fluxos e usos por ela propiciados, como peça infraestrutural e como edifício, e avaliar o grau de urbanidade que ela promove hoje, confrontando essa performance com a performance imaginada originalmente.

A premissa é que projetos de infraestrutura podem ser concebidos de maneira a transcender a função estrita a que se destinam dentro de determinado sistema técnico e assim contribuir para aumentar o grau de urbanidade do ambiente em que se inserem. E que projetos de edifícios, por sua vez, incorporando dispositivos próprios de projetos de infraestrutura também podem contribuir para o aumento do grau de urbanidade do lugar em que se instalam. A plataforma rodoviária de Brasília, sendo simultaneamente os dois - infraestrutura e edifício - e pensada desde a origem com uma função dupla - rodoviária e espaço de socialidade apresenta um rico campo de análise para compreender como o potencial de urbanidade se realiza materialmente.

\footnotetext{
1 A noção de "coisa" é usada por teóricos, como Bruno Latour, para dar conta do mundo material que entorna os "humanos". As "coisas" não são apenas objetos materiais, e objetos no sentido moderno do termo (em oposição a um sujeito); as "coisas" devem ser entendidas como dotadas de agência, na medida em que elas atuam no mundo, e produzem consequências no mundo e na vida das pessoas. Um exemplo mais claro é um semáforo, cuja mudança de luz "faz" as pessoas andarem ou pararem. Um livro "faz" um sujeito ler, um cigarro "faz" fumar. Nesta forma de descrever esses fenômenos, evita-se a separação moderna entre natureza e cultura (mundo natural e artificial) e a ideia de representação que ela implica, e recusa-se a pretensão de uma análise objetiva do mundo. Em lugar da objetividade da análise, reconhece-se subjetividade nas "coisas" (agência), tomando as relações entre humanos e coisas como relações simétricas (sem hierarquia).

2 O termo "agência", derivado do inglês agency é definido no Dicionário Houaiss como "capacidade de agir". A acepção que tenho em mente aqui é aquela utilizada por Alfred Gell em Art and Agency, para desenvolver sua teoria antropológica da arte, e mais especificamente, dos objetos/ obras de arte. Gell fala de "agência" quando se refere a um sistema de ação imbuído de intencionalidade e capacidade de transformação do mundo, tratase de uma "rede culturalmente prescrita para pensar sobre causalidade, quando o que acontece é (de certo modo vago) suposto de ser intencionado previamente por alguma pessoa-agente ou coisa-agente" (1998: 17). Atribuir agência a algo seria, nesse sentido, atribuir mente ou intenção, não importa se a pessoas ou coisas.
} 


\section{Infraestrutura e Arquitetura}

Obras de infraestrutura são aqui entendidos como estruturas físicas que promovem ou permitem fluxos de diferentes naturezas, e que constituem a base material para a possibilidade de existência da cidade. Tais estruturas físicas distribuem-se pelo território de forma sistêmica, dotando-o de potencial técnico para sustentar a vida. Configuradas em rede com pontos de articulação entre os seus ramais, formam sistemas, com diversas organizações hierárquicas possíveis e diferentes graus de complexidade. Nas áreas urbanas atuam diversos sistemas infraestruturais - sistema de transportes, abastecimento de água e drenagem, comunicação -, necessariamente sobrepostos e em interação entre si. Essas articulações ocorrem portanto não apenas entre partes do mesmo sistema mas também entre diferentes sistemas.

Como exemplo dessa intensidade e interação entre as redes infraestruturais e seu papel na vida das cidades podemos imaginar a seguinte situação urbana: um canal navegável, que participa, simultaneamente, de uma rede de drenagem de determinada porção de terra, serve de rota para um veículo de transporte público, uma barca de passageiros. Em uma bifurcação desse canal há uma estação de parada do sistema de transporte público. Até aqui são dois sistemas infraestruturais sobrepostos, compartilhando um nó de articulação entre dois ramais. A partir desse ponto, o usuário pode desembarcar e, no caso da estação estar em uma área urbana, deslocar-se até a estação de trem que está em uma ponte sobre o cruzamento dos canais e conectar-se a uma nova rede de transportes, ou sair a pé, pelas calçadas laterais a uma rua pela qual passam carros e ônibus, e que por sua vez compartilham a ponte com a estação de trem, em outro nível. Nessa pequena cena, corrente em ambientes urbanos desde o início do século $\mathrm{XX}$, testemunha-se a enorme complexidade criada pela sobreposição e, sobretudo articulação de redes infraestruturais: um sistema de canais de drenagem, um sistema de transporte aquático, um sistema de transporte sobre trilhos, um sistema rodoviário, sobre o qual corre o sistema de transporte de ônibus, mas também incorpora as vias pelas quais o pedestre e as bicicletas podem circular, a rede de cap- 
tação primária da drenagem que conduzirá a água da chuva ao canal e o acesso às galerias de instalações técnicas pelas quais correm as redes de energia, que alimentam o trem, a iluminação e o edifício da estação. Esse nó, configurado pela ponte-estação sobre a bifurcação do canal, articula pelo menos oito sistemas infraestruturais sobrepostos. Todas as atividades descritas na cena são de natureza funcional e permitem uma razoável variedade de alternativas de atuação. Desde garantir que essa porção do território seja frequentável, pois não é alagadiça, até garantir o percurso de distâncias a pé pelas calçadas, ou a um outro ponto a 500 km dali, usando o trem sobre trilhos etc. Graças a essa densidade de redes infraestruturais interconectadas, cria condições para a produção de um espaço social mais completo. A partir das redes infraestruturais, desenhadas de forma eficiente para irrigar o território com suas funções técnicas, erigem-se edifícios que garantem moradia e implantação de empreendimentos comerciais, educacionais ou produtivos de qualquer natureza, ou seja, elas permitem a instalação das pessoas e instituições que compõem a vida em "sociedade". Essa poderia ser uma descrição da estrutura básica da cidade tradicional, quase um modelo de reprodução do espaço urbano contemporâneo.

A partir dessa apreensão da constituição do espaço urbano, poderia se dizer que a cidade tradicional segrega o território em, de um lado, o espaço da infraestrutura e, de outro, o espaço dos edifícios, ou da arquitetura, que se interconectam e sobrepõem, mas que em geral se mantêm como esferas separadas, seja na produção dos projetos e sua implantação, nos profissionais envolvidos nessas atividades, ou na gestão e na especialização dos tipos de uso. Essa separação entre infraestrutura e arquitetura coincide, em boa parte dos casos, com a separação do que se define como "espaço público" e "espaço privado". E ainda, obras de infraestrutura costumam ser fruto de investimentos públicos enquanto as obras de arquitetura, de investimentos privados. 


\section{urbanidade}

O conceito de urbanidade atende a diversas acepções, cabe definir a que emprego aqui em relação a outras acepções correntes.

O pesquisador Douglas Aguiar faz uso das acepções como descritas em dicionário, em que "urbanidade é o caráter do urbano" e "uma definição em sentido figurado, que é aplicável à conduta das pessoas, referindose a atributos tais como cortesia, delicadeza, polidez, civilidade" para definir urbanidade como termo que, usado ao nos referirmos à cidade, "significa estarmos falando de uma cidade ou de um lugar que acolhe, ou recebe, as pessoas com civilidade, com polidez, com cortesia. Ou, na mão contrária, estaríamos nos referindo a situações destituídas dessas características positivas, situações que ao invés de evidenciarem cortesia e polidez, evidenciam hostilidade às pessoas, ao corpo." (Aguiar, 2012). Nessa concepção a urbanidade expressa civilidade, isto é, é um atributo da relação entre coisas e pessoas, e se caracteriza por esta se dar de modo acolhedor, gentil.

Já para o professor da UNB, Frederico de Holanda a "urbanidade é um atributo social que implica visibilidade do outro, negociação de papéis e frágeis fronteiras entre eles, mobilidade social, estruturas societárias mais simétricas etc." e a arquitetura, identificada por ele como espaço de modo geral, é uma condição, apenas o lugar onde a urbanidade se dá e que para tanto requer determinadas características que a possibilitem. [Holanda, 2010]. Assim Holanda separa, em uma relação de causa e efeito de mão dupla, sociedade e espaço, com claro acento na dimensão social.

Nesta reflexão, a urbanidade se define como um atributo da vida na cidade, medida pelo grau de intensidade, variedade e quantidade de experiências ou interações possiveis, entre humanos e não humanos, em determinado ambiente. Não há implicado um juízo acerca da qualidade dessa experiência, ou seja, evita-se deliberadamente uma concepção moralista que classifique a experiência como positiva ou negativa. 
Nesse sentido, o conceito de urbanidade adotado aqui se assemelha ao conceito de socialidade definido por antropólogos contemporâneos (Latour, 2005, Strathern, 1989), em contraste com o de sociabilidade. A distinção diz respeito à diferença entre a concepção de senso comum de sociabilidade, que supõe uma convivência marcada por certo sentimentalismo, e uma concepção amoral que explora um "relacionismo" entre os agentes envolvidos: território, construção, passantes, usuários, políticas públicas etc.

Um ambiente tem portanto um maior grau de urbanidade na medida em que proporciona a maior diversidade, quantidade e intensidade de interações entre as coisas e pessoas que lá estão.

\section{dispositivos de urbanidade}

Em projetos de obras infraestruturais e de arquitetura é possível identificar alguns dispositivos, espaciais ou associados ao programa ou função, que promovem um aumento no nível de interação entre as partes e, portanto um acréscimo do grau de urbanidade.

Em obras de infraestrutura esses pontos de maior intensidade estão associados às articulações, internas às redes a que pertencem, mas também entre as diferentes redes sobrepostas. Em geral esses pontos correspondem aos nós da rede, que permitem entrada e saída, ou conexão e acesso- como a estação de trem que permite o acesso de pessoas ao trem e as conecta do sistema viário pelo qual vinham a pé ao sistema ferroviário, em que se locomovem por trem - ou aos pontos de cruzamento dos sistemas - a ponte pela qual o trem transpõem a avenida, os chamados ambientes de mobilidade.

Os dispositivos que promovem essas articulações são os pontos em que há maior intensidade de troca. Interessa portanto analisar como são pensados e materializados esses nós de intersecção, conexão, acessos e cruzamento entre sistemas, na medida em que, através de seu desenho, garantem articulação através de continuidade e transposição - dois dis- 
positivos recorrentes em redes infraestruturais.

Mas, mesmo nesses pontos de maior potencial de urbanidade, os usos tendem a ser extremamente especializados e com isso a variabilidade, imprevisibilidade e intensidade de experiência tendem a ser rebaixadas. São em geral projetados de modo em que predominam a resolução de aspectos técnicos e os critérios de eficiência máxima. Há portanto também nos nós de articulação uma forte preponderância dos aspectos funcionais sobre questões formais. Tanto que a beleza dos projetos de infraestrutura é comumente associada à eficiência, desempenho, performance e não há aspectos semânticos ou de representação explicitados em sua formalização a não ser os da exibição de alta tecnologia e racionalidade construtiva. Também não há lugar em um projeto de infraestrutura para a indeterminação programática como forma de permitir usos e apropriações imprevistas. A austeridade ou racionalidade em sua formalização representam o investimento público, em oposição aos edifícios, que são o lugar da representação dos poderes individuais, privados.

Os projetos de arquitetura, por sua vez, tendem a conceber edifícios como objetos, que se conectam aos sistemas infraestruturais de modo controlado e quase nunca entre si. A maior parte dos edifícios que compõem a cidade tem seu uso determinado e também permite pouca variedade de experiência, mas há um grau de liberdade na exploração formal e programática na prática arquitetônica muito superior ao dos projetos infraestruturais. A prática arquitetônica tem uma flexibilidade maior com relação à manipulação do programa do que a prática da engenharia.

Embora afetada pelas restrições inerentes aos modos de produção privados, é comum haver em projetos de edifícios a possibilidade de incorporar novos programas, ou propor articulações entre programas que criam novos usos e sentidos e apropriações imprevistas do espaço, aumentando a variação e intensidade das experiências. Mas é especialmente nos aspectos formais dos edifícios que a prática arquitetônica desfruta tradicionalmente de mais liberdade se comparada à da engenharia. É na manipulação da forma e dos materiais que grande parte da produção da 
disciplina arquitetônica concentra seu foco de atuação. A criação de sentido e novas articulações - o discurso arquitetônico - usa geralmente a forma como variante entre programas similares e como forma de expressão. A manipulação da forma e os materiais empregados não são apenas resolução eficiente de uma equação técnica, mas veículo expressivo e portanto, fonte de experiência.

Sendo assim, se nos projetos infraestruturais os pontos de maior potencial de urbanidade são os pontos de fricção ou articulação, em que se utilizam dispositivos de continuidade e transposição, nos projetos arquitetônicos os recursos que potencializam o grau de urbanidade de determinado ambiente pela criação de variedade e intensidade de experiência são a manipulação programática - como sobreposição de usos ou espaços indeterminados - e a manipulação formal - tamanho e posição das coisas, materiais utilizados, visuais.

Admitindo que promover a intensificação da vitalidade urbana é desejável como resultado das intervenções na cidade, a hipótese aqui, portanto, é de que o potencial de urbanidade produzido por projetos que atuam sobre a cidade poderia ser maior na medida em que as fronteiras entre as disciplinas se diluem, em situações em que projetos de edifícios incorporem dispositivos próprios da infraestrutura de forma clara, promovendo continuidades e transposições, ou em projetos de infraestrutura que incorporem recursos de manipulação programática e formal próprias da arquitetura, afrouxando as amarras da eficiência técnica. Essa capacidade de aumentar o potencial de urbanidade pode ser levado ao extremo, entretanto, em intervenções construídas no território em que se fundem em um só lugar o projeto de infraestrutura com o projeto de um edifício. Esse é o caso da plataforma rodoviária de Brasília. 


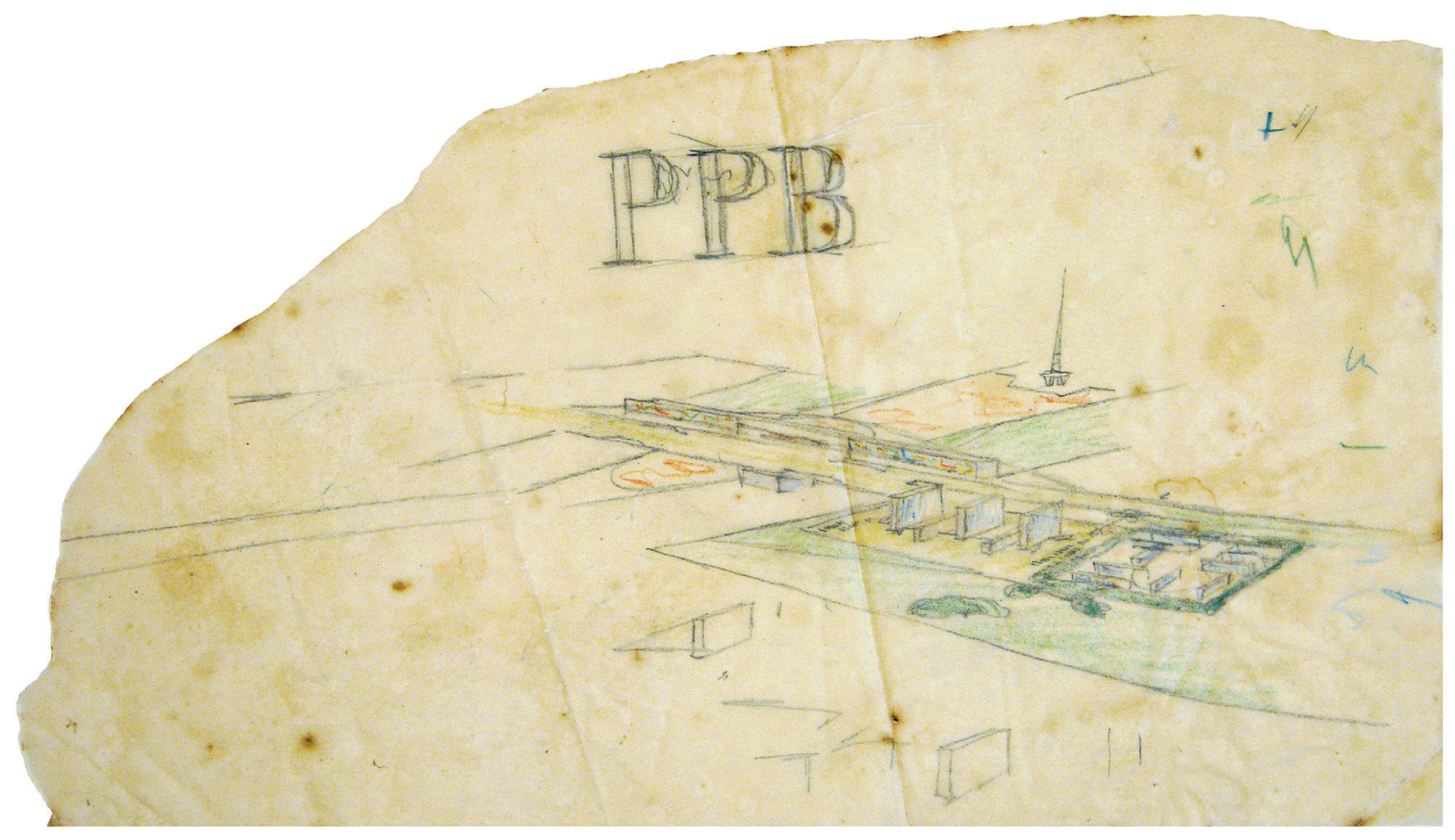

fig. 2 - Croqui de Lucio Costa para o setor central de Brasília, elaborado como estudo prévio à entrega do concurso. Nele aparecem a plataforma rodoviária e a Torre de Rádio e TV. É interessante notar como a plataforma não tem forma determinada e se funde ao terreno da cidade, em contraposição à vertical marcante e identificável da torre. Fonte: Acervo Casa de Lucio Costa.

fig. 3 - Croqui de Lucio Costa para a Torre de Rádio e TV em que se nota a preocupação formal com a estrutura. Fonte: Acervo Casa de Lucio Costa. 


\section{A plataforma rodoviária de Brasília}

Tendo em vista o conjunto de questões descritas acima vale explicitar quais são as características da plataforma rodoviária de Brasília que a tornam um campo de análise profícuo.

Em primeiro lugar ela é peça fundamental do sistema infraestrutural mais determinante da cidade de Brasília. Além de lugar de resolução viária do cruzamento dos eixos macroestruturadores da cidade, abriga no desnível criado para operar a transposição, a estação rodoviária da cidade. Anos após a inauguração tornou-se parte da rede de Metrô e hoje passam por ela diariamente duas vezes mais pessoas que as que habitam o Plano Piloto. Ou seja, é um importante nó infraestrutural, articulador de um grande e complexo sistema de transporte público.

Por outro lado, a plataforma foi concebida como peça de articulação entre diversos setores da zona central de Brasília. Os setores previstos para abrigar predominantemente as funções de maior vitalidade de uma cidade -diversões, hotéis, comércio - se distribuem em seu entorno. Ainda hoje, apesar das alterações em relação ao projeto original, seus grandes espaços permitem a conexão física e visual desse recinto. Além das articulações entre vários setores graças às suas dimensões, os espaços constituintes da estrutura abrigam uma grande variedade de serviços e atividades, formais e informais, que se beneficiam do fluxo intenso decorrente de sua função de estação rodoviária, mas que por si atraem também um público muito numeroso.

Além dessas funções superpostas que se contaminam mutuamente, a formalização do projeto é muito particular. Não apresenta uma forma apreensível de imediato, em parte devido à sua dimensão mas também porque se realiza no vazio entre os dois planos sobrepostos do cruzamento dos eixos Monumental e Rodoviário-residencial, fruto de intervenção topográfica de grande escala. E, apesar das grandes peças estruturais necessárias para a construção desses recintos, o projeto renuncia à expressividade formal. Diferentemente da Torre de Rádio e TV (figs. 2 a 5), o outro único projeto de Lucio Costa em Brasília, aparte do Plano Piloto, e 


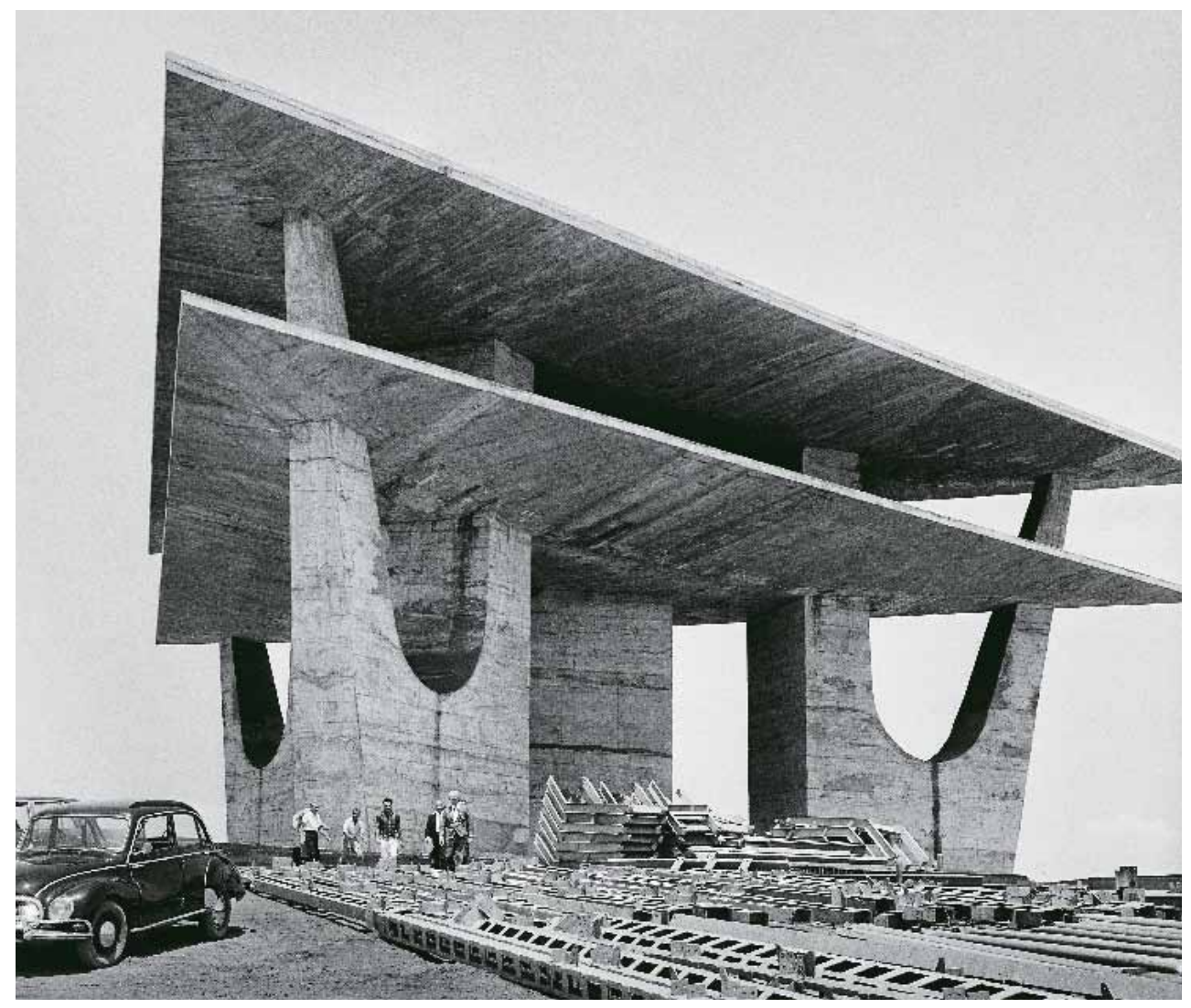

fig. 4 - Foto da base da Torre de Rádio e TV em concreto armado moldado in loco, ainda em obras. Chama a atenção a exploração da expressividade do material por Lucio Costa em comparação com a estrutura da plataforma rodoviária. Fonte: Arquivo Público do Distrito Federal.

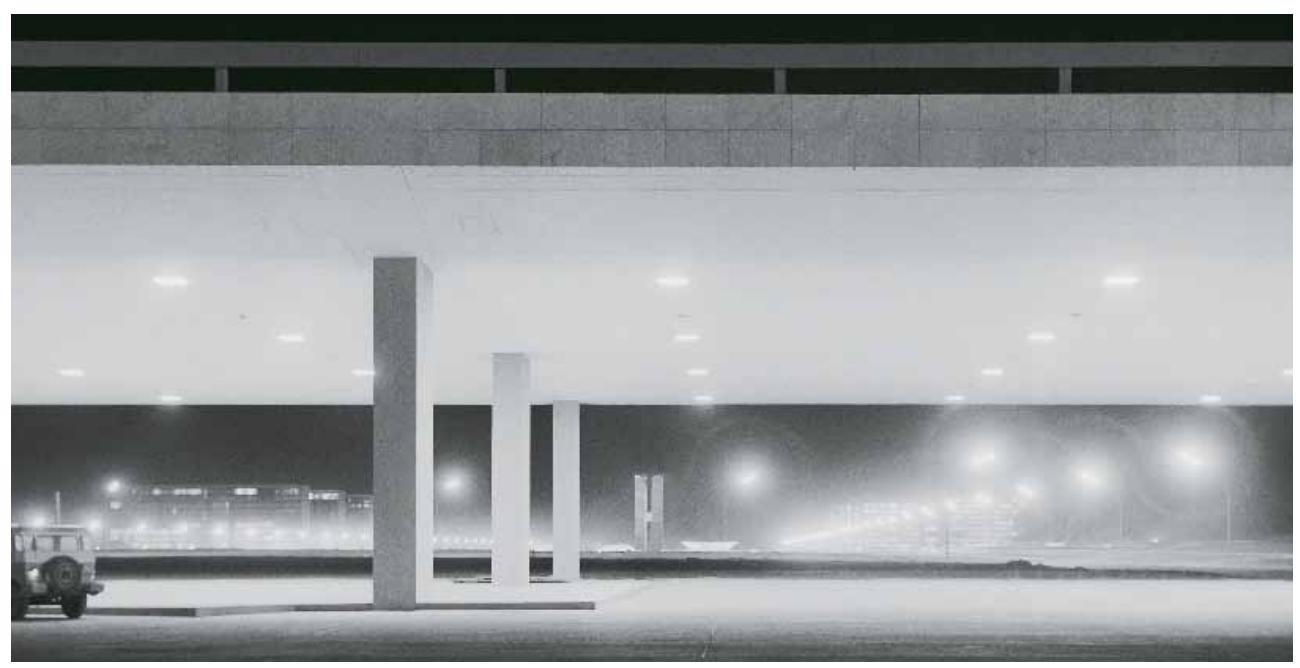

fig. 5 - Imagem do nível inferior da plataforma rodoviária recém inaugurada. Ao fundo, o Congresso Nacional. Nesta imagem é notável a discrição da estrutura, toda branca, pintada ou revestida em mármore, apesar de suas dimensões monumentais. Fonte: Arquivo Público do Distrito Federal. 
que também se refere ao centro de uma rede infraestrutural, a plataforma rodoviária tem suas peças estruturais e muros revestidos com mármore, cerâmica e pintura brancos, criando planos discretos.

É portanto uma construção que reúne atributos de um projeto de infraestrutura, de um edifício (ou projeto de arquitetura), tem uma atuação técnica marcante na estruturação da cidade, e abriga e articula simultaneamente diversas atividades, previstas e não previstas em seu programa. Ela desfaz assim os limites entre infraestrutura e arquitetura, entre edifício e cidade, em um ambiente com alto grau de urbanidade.

\section{campo disciplinar}

O projeto de Lucio Costa para Brasília teve a virtude de incorporar "elementos históricos: perspectivas barrocas, terraplenos monumentais, gregarismo colonial brasileiro, acrópole cerimonial, cidade linear, cidadejardim, urbanidade de áreas comerciais. Uma cidade distinta das manifestações urbanísticas modernas no resto do mundo. Só o faria quem estivesse 'desarmado de preconceitos e tabus urbanísticos'" (Costa, 1995, p. 282)" (Holanda, 2009).

Além da demonstração da erudição urbanística do autor, o projeto de Brasília representa um exemplo de superação da distinção do edifício como objeto isolado sobre um plano contínuo, conectado e irrigado pelos sistemas infraestruturais, propugnada pelo urbanismo moderno de matriz corbusiana. Para Costa, Brasília deveria "ser concebida não como simples organismo capaz de preencher [...] as funções vitais próprias de uma cidade moderna qualquer" (Costa, 1995), mas, alcançar a monumentalidade desejável à capital do país por meio de um desenho definido e específico, adaptado ao lugar (Braga, 2010, p. 223) em que a estrutura urbana e seus edifícios estão relacionados de forma indissociável, para além da função específica de cada parte, contribuindo para a obtenção de um alto grau de urbanidade.

Na plataforma rodoviária esse procedimento se manifesta de forma con- 
tundente e exemplar, na medida em que não pode ser apreendida apenas como edifício, ou apenas como infraestrutura, mas, já foi dito, como ambos, simultaneamente. Embora seja concebida, como Brasília, "segundo modernos princípios da técnica rodoviária" (Costa, 1995), a plataforma rodoviária, ao fundir os atributos de edifício, infraestrutura, centro de socialidade e paisagem, supera uma visão funcionalista orgânica do urbanismo moderno e se aproxima de experiências ou formulações ligadas a discursos críticos do modelo corbusiano, como os projetos de cidades contínuas de Yona Friedman, ou a Nova Babilônia de Constant Nieuwenhuys ou ainda as megaestruturas, como definidas por Banham (Banham, 1976), em que as funções da cidade se mesclam e superpõem, criando campos de experiência intensa.

No campo disciplinar essa operação produzida pelo Plano Piloto, e especificamente a produzida na plataforma rodoviária, coloca a questão das atribuições e efetividade das práticas da arquitetura, engenharia e urbanismo e especialmente do potencial do desenho na atuação em ambientes urbanos. Uma medida do impacto de cada prática na transformação urbana hoje poderia ser aferir o volume de investimento necessário para construir um hipotético trecho de cidade, comparando os valores e tempos destinados a obras de infraestrutura, o destinado a projetos e obras de urbanismo e desenho urbano e o destinado à construção de edifícios, ou à arquitetura. Por esse critério a engenharia é de todas as práticas implicadas a que intervém e determina mais fortemente a forma e o crescimento da cidade. Em grande medida, no entanto, os projetos de engenharia não demonstram consciência do potencial e da influência que os sistemas infraestruturais têm na formalização da cidade e na determinação do seu grau de urbanidade. Nessa avaliação, talvez a prática do urbanismo é hoje, no Brasil, seja a menos efetiva na construção do ambiente urbano.

O que a Plataforma Rodoviária apresenta como exemplo relevante na discussão disciplinar é a possibilidade de reivindicar para o desenho o papel de ator efetivo na produção de um alto grau de urbanidade. Ou seja, a possibilidade de fundir em uma atuação integrada as especialidades disciplinares - projetos arquitetônicos, de infraestrutura, de urbanismo. 
capítulo 2 - A plataforma hoje 


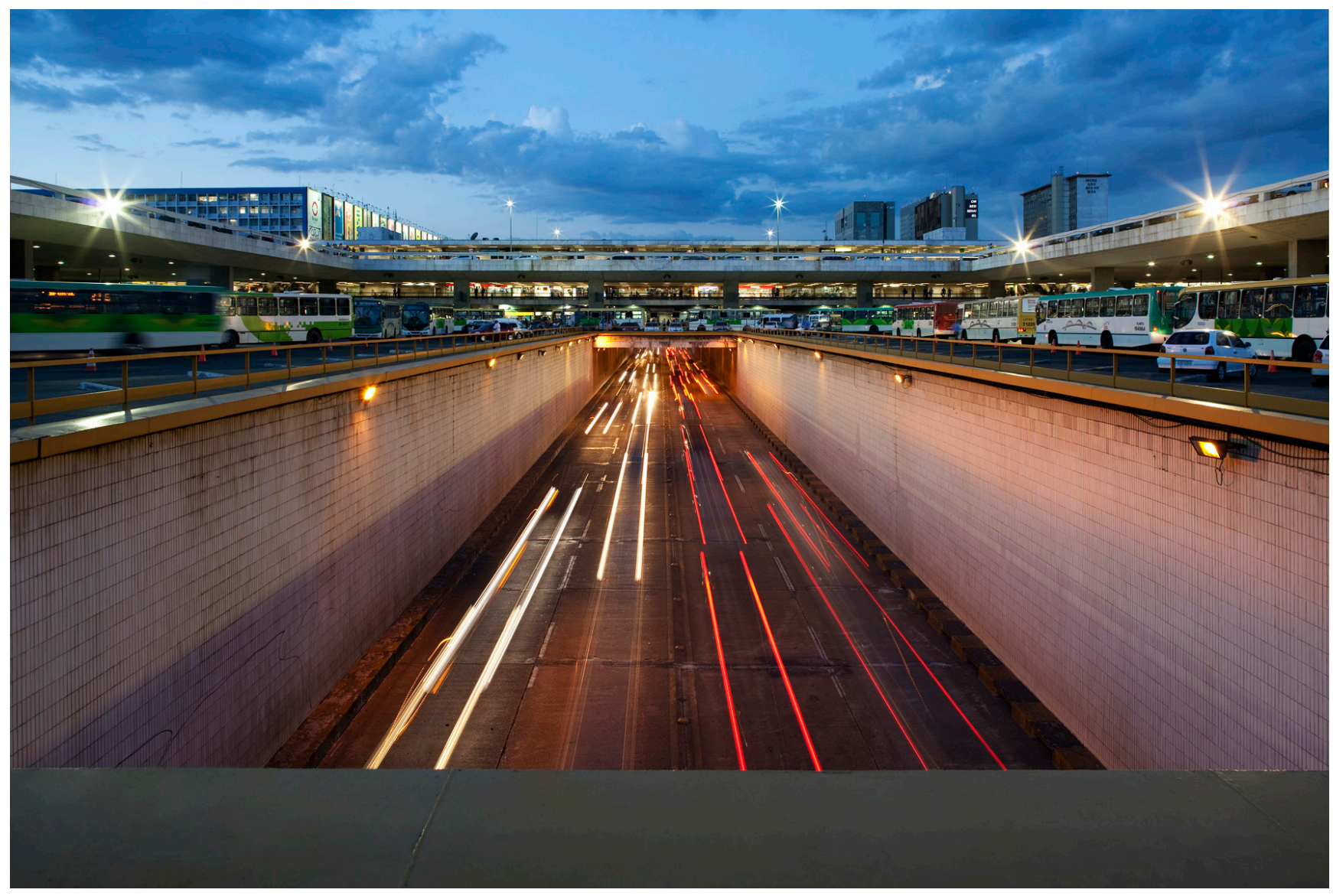

fig. 6 - Nesta imagem é possível ver, em primeiro plano, a passagem expressa do eixo monumental, entrincheirada. Ao lado, nota-se a circulação dos ônibus junto às plataformas, no nível correspondente à estação própriamente dita. Ao fundo, o mezanino de serviços e ainda, sobre ele o nível superior da plataforma, com sua marquise de acesso, que faz a conexão entre os centros de diversões, como o Conjunto Nacional, à esquerda. Fonte: Leonardo Finotti, 2010. 


\section{A plataforma hoje}

Neste capítulo buscarei descrever em detalhe a totalidade da plataforma rodoviária, em que serão analisadas: a) a estrutura espacial da plataforma, em sua materialidade; b) suas funções como nó infraestrutural; e c) suas funções como articuladora de diferentes recintos do setor central de Brasília.

\section{a. organização e descrição da plataforma rodoviária de Brasília}

A plataforma ocupa uma área de aproximadamente 800 metros de extensão por 170 m de largura e é organizada em quatro níveis (fig. 6):

I. nível inferior, 19 metros abaixo da cota da plataforma superior, com a passagem expressa de seis pistas do eixo rodoviário residencial, três em cada sentido, o chamado buraco do tatu (fig. 6); II. nível da estação rodoviária, 9.00 metros abaixo da cota superior, em que se localizam as maiores áreas cobertas, que abrigam as plataformas de embarque da rodoviária, parte do comércio, serviços eacesso à estação central do Metrô. Este nível coincide com o nível de passagem do eixo monumental; III. O nível do mezanino, 4.50 metros abaixo da cota superior, que abriga locais comerciais, especialmente de alimentação, e serviços públicos e IIII. Plataforma superior, aqui definida como o nível 0.00 , que abriga passagens peatonais, áreas de estacionamento e a marquise sob a qual estão instalados serviços como bilheterias, alimentação, informações e configura o principal acesso de pedestres à rodoviária, através de dois conjuntos de escadas e elevadores.

Esses quatro níveis são construídos com diferentes técnicas de concreto armado, adequadas às suas condições topográficas e dimensões de vãos 


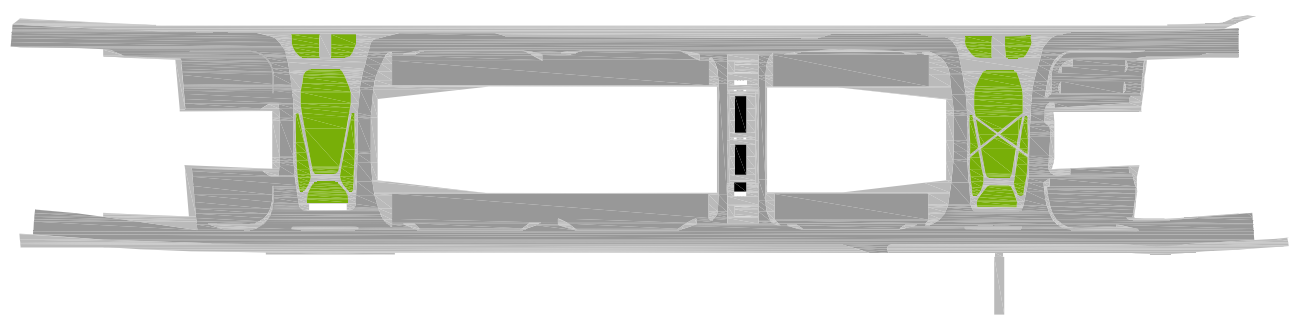

\section{nível superior}

automóvel $\left(58.663,00 \mathrm{~m}^{2}\right)$ pedestres $\left(28.155,00 \mathrm{~m}^{2}\right)$ jardim $\left(7.906,00 \mathrm{~m}^{2}\right)$ comercial $\left(461,00 \mathrm{~m}^{2}\right)$

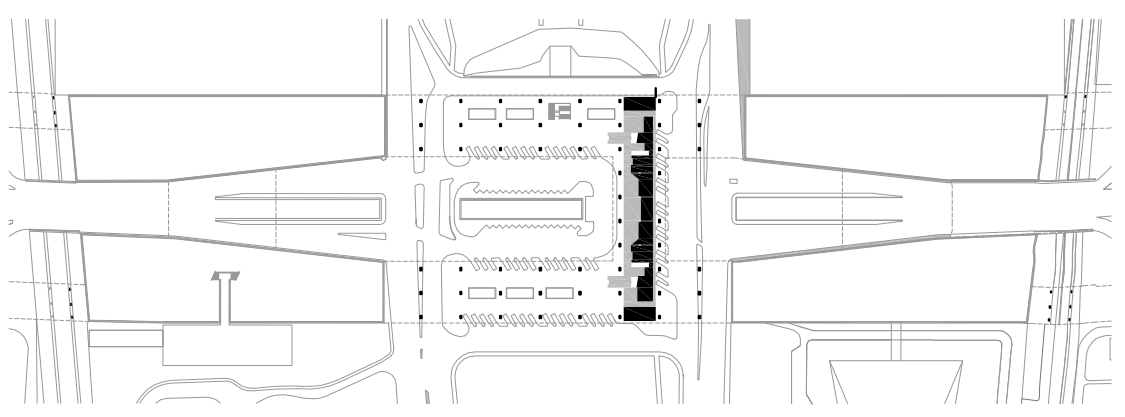

\section{mezanino}

pedestres $\left(1.988,00 \mathrm{~m}^{2}\right)$

comercial $\left(1.937,00 \mathrm{~m}^{2}\right)$

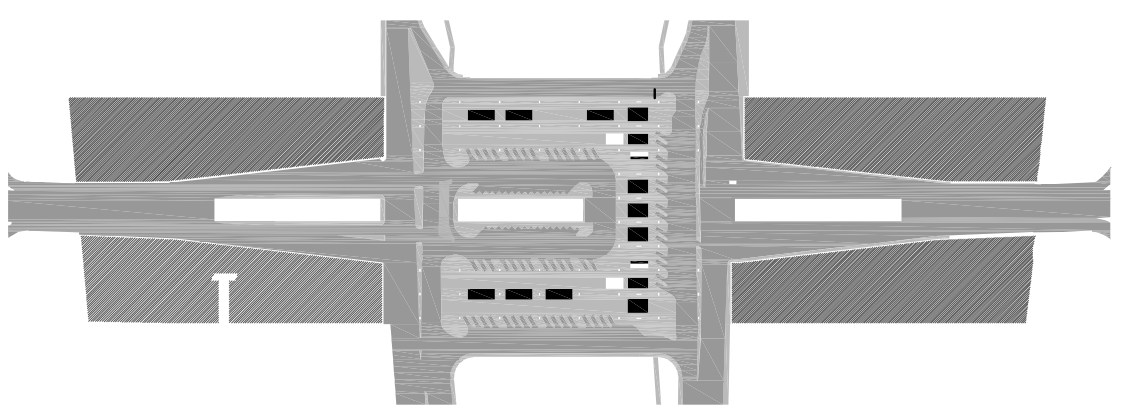

nível estação rodoviária

automóvel $\left(55.538,00 \mathrm{~m}^{2}\right)$ pedestres $\left(24.532,00 \mathrm{~m}^{2}\right)$ comercial $\left(2.066,00 \mathrm{~m}^{2}\right)$

\section{passagem subterrânea}

automóvel $\left(6.660,00 \mathrm{~m}^{2}\right)$

diagrama 1 - Nestes esquemas é possível notar a distribuição de áreas destinadas aos principais usos da estrutura. Além dos valores absolutos é interessante notar a forma que adquirem os espaços usados por veículos e pedestres. Com exeção do nível inferior, da estação rodoviária, as proporções dos espaços destinados ao pedestre tendem a ser estranguladas e pouco fluidas. Também é possível notar a grande quantidade de cruzamentos entre os sitsemas com poucos pontos de transposição eficiente para o pedestre.

\section{totais}

automóvel (120.861,00 m²) pedestres $\left(54.675,00 \mathrm{~m}^{2}\right)$ comercial $\left(4.464,00 \mathrm{~m}^{2}\right)$ jardim $\quad\left(7.906,00 \mathrm{~m}^{2}\right)$ 
e cujo projeto e obras serão analisadas mais detidamente no próximo capítulo. No entanto vale aqui descrever sumariamente sua materialidade. Os dois principais níveis são o da plataforma rodoviária (nível -9.00 m), assentado diretamente no solo e, como já dito, coincidente com o nível de passagem das vias do eixo monumental, e o superior, configurado por grandes pilares, vigas e lajes em concreto armado, que servem de cobertura à plataforma rodoviária. O nível inferior, com suas rampas e passagem sob a rodoviária, é totalmente escavado no terreno e configurado por dois muros laterais de contenção, também em concreto armado. $\mathrm{O}$ mezanino é uma estrutura em concreto armado autônoma em relação às demais e composta por uma laje em concreto armado sobre uma série de pilares centrais, também nesse material. Como última peça estrutural que compõe o conjunto há a cobertura em concreto, ou marquise, localizada a três metros acima da plataforma superior e que abriga os acessos aos níveis inferiores.

A altura total da estrutura é de 22,50 metros, entre a cota mais baixa da passagem expressa e a cota superior da laje da marquise de acesso. $\mathrm{Ou}$ o equivalente a um edifício de 7 pavimentos, e praticamente a mesma altura dos centros de diversões em seu entorno.

\section{Áreas}

A área total da plataforma, somados os quatro níveis é de 187 mil metros quadrados. Desses, 120 mil metros quadrados, ou 60\%, são reservados ao trafego sobre rodas. 54 mil metros quadrados, ou 35\% são destinados à circulação de pessoas. 4,5 mil metros quadrados, ou 3\% são jardins, e 8 mil metros quadrados, ou $5 \%$, são áreas fechadas ao público, correspondentes a serviços ou comércio.

Apesar desses números totais serem significativos no sentido de mostrar a importância dedicada às áreas de convivência, é mais produtivo separar essa análise em dois níveis principais: o nível superior, dedicado à conectividade peatonal, de articulação entre os edifícios do entorno e portanto à articulação dos demais setores; e o nível inferior, em que se instala a 


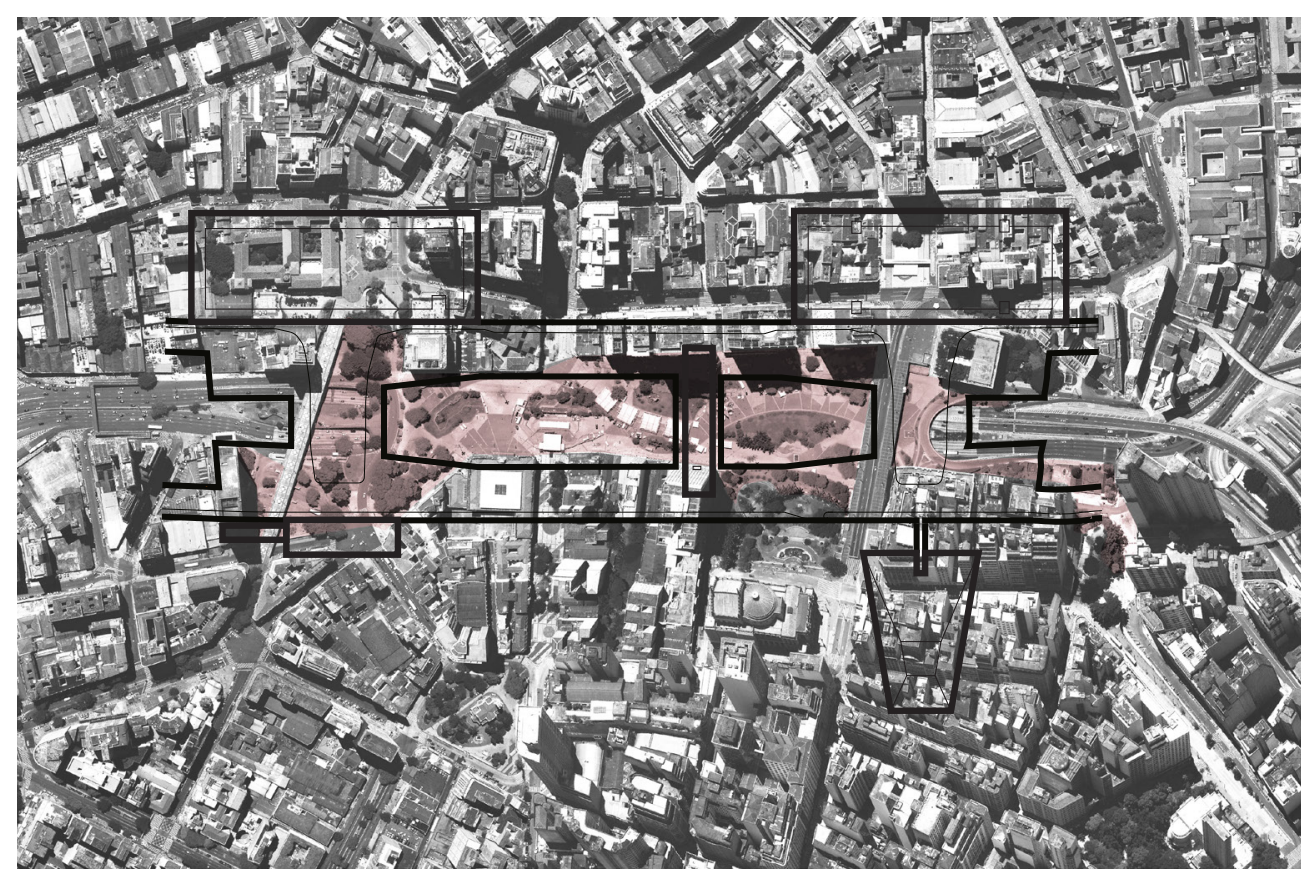

diagrama 2 - Sobreposição da plataforma rodoviária com o vale do Anhangabaú, entre os viadutos do Chá e Sta. Ifigênia, em São Paulo.

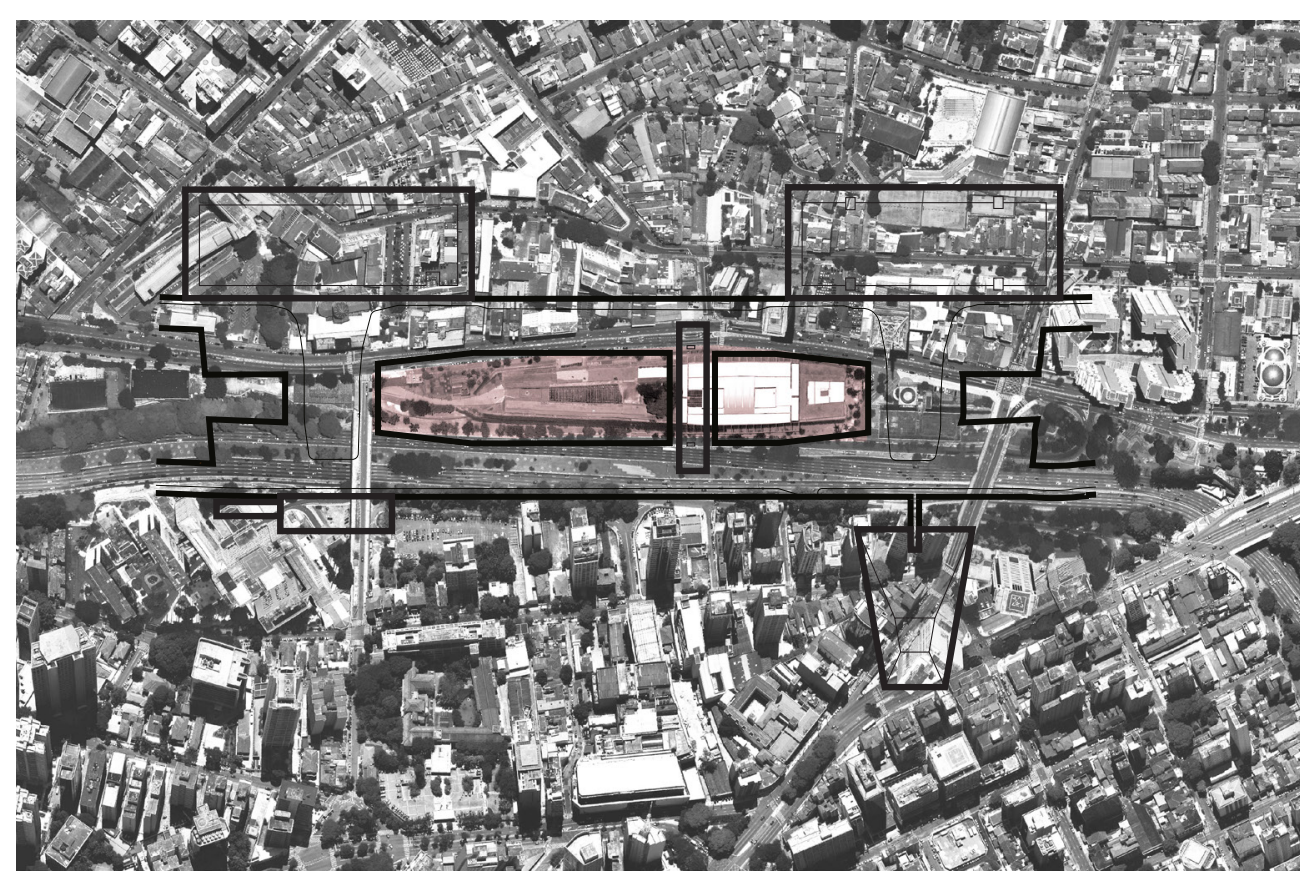

diagrama 3 - Sobreposição da plataforma rodoviária com o Centro Cultural São Paulo, entre a Rua Vergueiro e Av. 23 de Maio, em São Paulo. 
estação rodoviária propriamente dita.

Observando a tabela com as áreas do nível superior podemos verificar que a área destinada aos pedestres é pequena se comparada à área destinada a estacionamento e, observando a forma e proporção das áreas de pedestres indicadas no diagrama 1, podemos notar que são faixas estreitas, pouco eficientes para promover o fluxo intenso e agradável de pessoas. As áreas de jardim são mínimas, gramadas, e restringem a livre circulação peatonal. A região central de Brasília tem efetivamente um déficit de vagas de estacionamento alto, mas o pedestre neste caso está prejudicado. A desproporção dos usos é tão evidente que há estudos para buscar soluções subterrâneas de estacionamento sob as praças, já considerados pela administração regional.

Observando o nível inferior é possível notar maior equilíbrio entra as áreas destinadas à circulação de pessoas face às áreas destinadas a circulação de veículos. A grande área disponível, mas principalmente a forma que ela assume, com largas esplanadas e amplos corredores de circulação, são condição para a possibilidade de convivência entre o comércio intenso e a função de embarque e desembarque das quatro plataformas. Embora a proporção seja mais equilibrada, neste nível observa-se uma deficiência dos dispositivos de transposição dos fluxos de veículos por parte do pedestre. As passagens e travessias são em nível e em geral insuficientes.

\section{tamanho}

A dimensão dos espaços da plataforma rodoviária é o atributo mais importante na boa performance do edifício, seja em sua função técnica, como infraestrutura de transporte, ou em sua função de espaço de articulação urbana. Não fossem as dimensões extremamente grandes de seus espaços a rodoviária não teria condições de absorver um volume enorme de linhas e passageiros, ou transformar-se em estação intermodal de transportes em escala metropolitana, função que vem exercendo desde a implantação da rede de Metrô. 


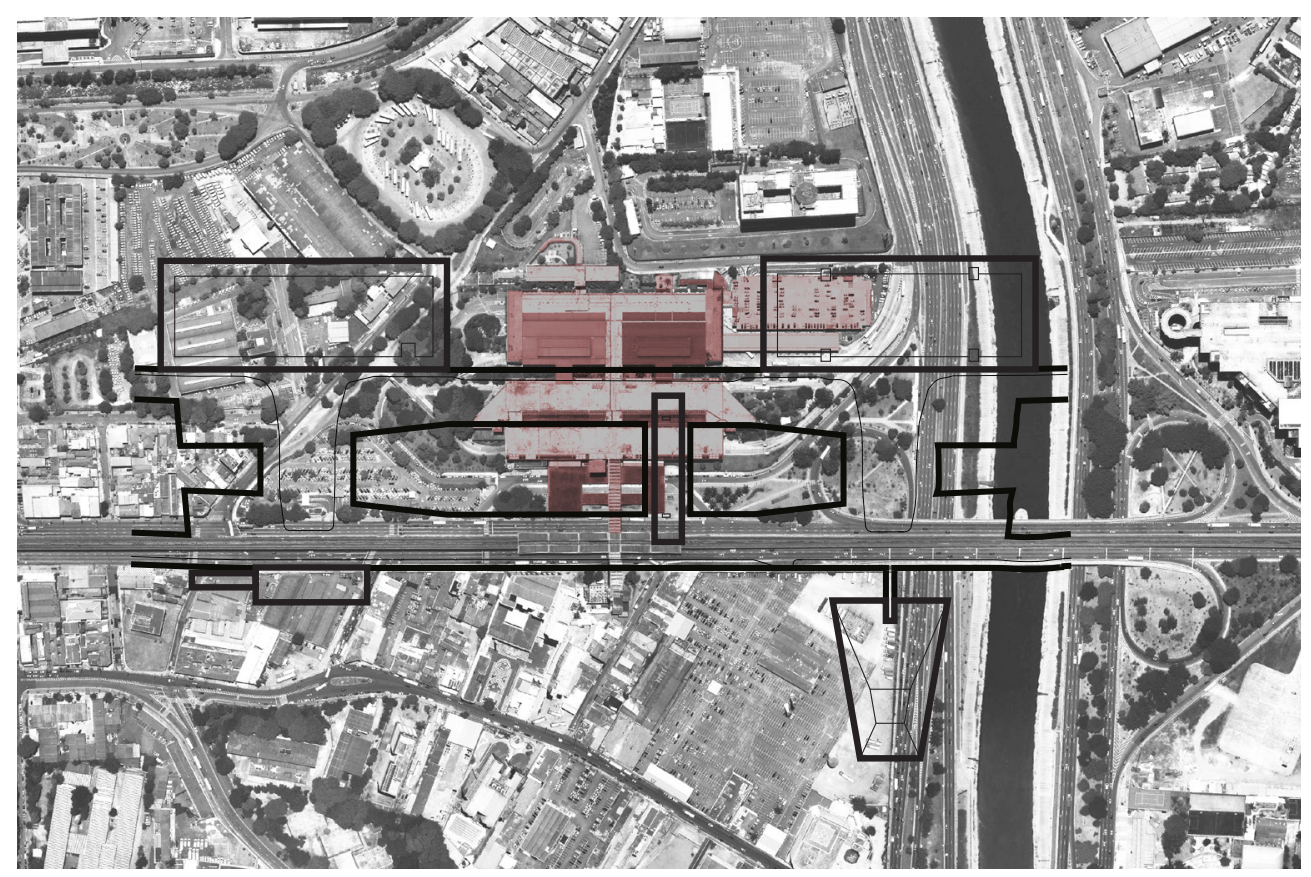

diagrama 4 - Sobreposição da plataforma rodoviária com a estação rodoviária do Tietê, em São Paulo.

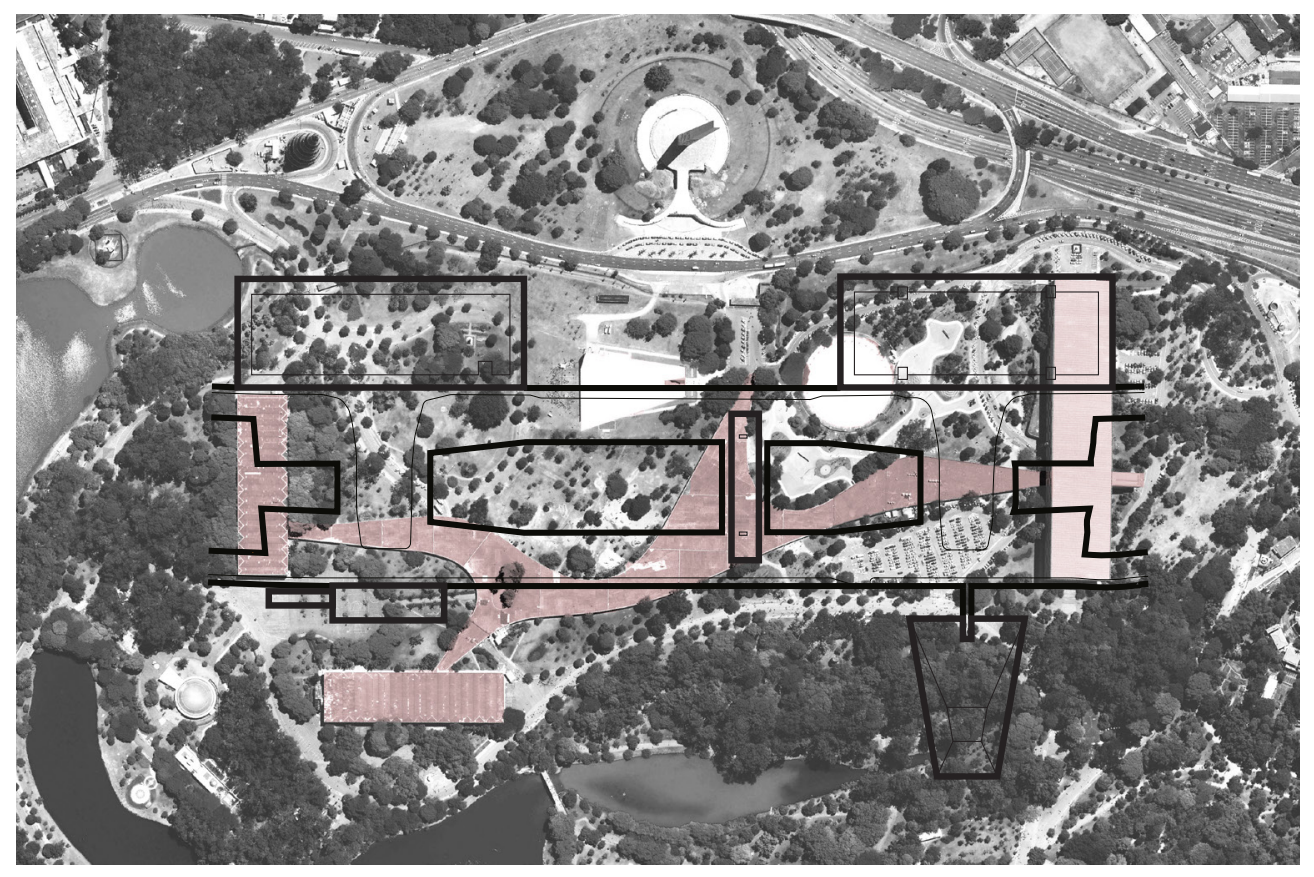

diagrama 5 - Sobreposição da plataforma rodoviária com a marquise do Parque lbirapuera, em São Paulo. 
Essa mesma generosidade de seus espaços, digamos, internos, com seus quase oitocentos metros de comprimento, é também a condição para a conexão física direta entre edifícios com a escala dos centros comerciais ou de um teatro para até dois mil espectadores. Mas também é essa disponibilidade que permitiu o desenvolvimento de uma série de atividades que se tornaram parte de sua essência e a transformaram em um lugar de intensa urbanidade. O comércio que floresceu ali ao longo de sua história e a sustentação econômica desses negócios não se deve apenas ao grande fluxo de pessoas próprio de sua função como rodoviária, conformando um potencial mercado consumidor, mas principalmente por que a estrutura espacial dispunha de área suficiente, talvez até excessiva em um primeiro momento, para que essas atividades se desenvolvessem. Prova disso é que houve por muito tempo um intenso comércio informal no nível superior, desalojado apenas recentemente pelo poder público. Um famoso ponto turístico de Brasília é o quiosque de pastéis localizado no nível da plataforma de embarque.

A dimensão da plataforma torna-se mais evidente ao ser comparada a outras estruturas urbanas em áreas metropolitanas. Seu tamanho aparece como um atributo formal fundamental para a produção efetiva de um alto grau de urbanidade. A escala metropolitana que ela veio a adquirir já estava prefigurada no Plano Piloto graças a sua dimensão.

Nos diagramas comparativos de escala (diagramas 2 a 5 ) pode-se avaliar a dimensão dos espaços da Plataforma se comparados a recintos de usos diversos e escala semelhante.

\section{articulação vertical}

Como já dito, o cruzamento dos dois eixos em níveis diferentes determina os dois principais planos que configuram o edifício. $O$ eixo rodoviário passa na cota superior e o eixo monumental, na cota inferior. $O$ edifício aparece na articulação desse dois níveis. A primeira articulação portanto, e que determina a uma só vez a forma e a função primordiais da plataforma rodoviária, é a articulação vertical, entre as cotas do desnível obtido através de uma grande obra de terraplenagem. 


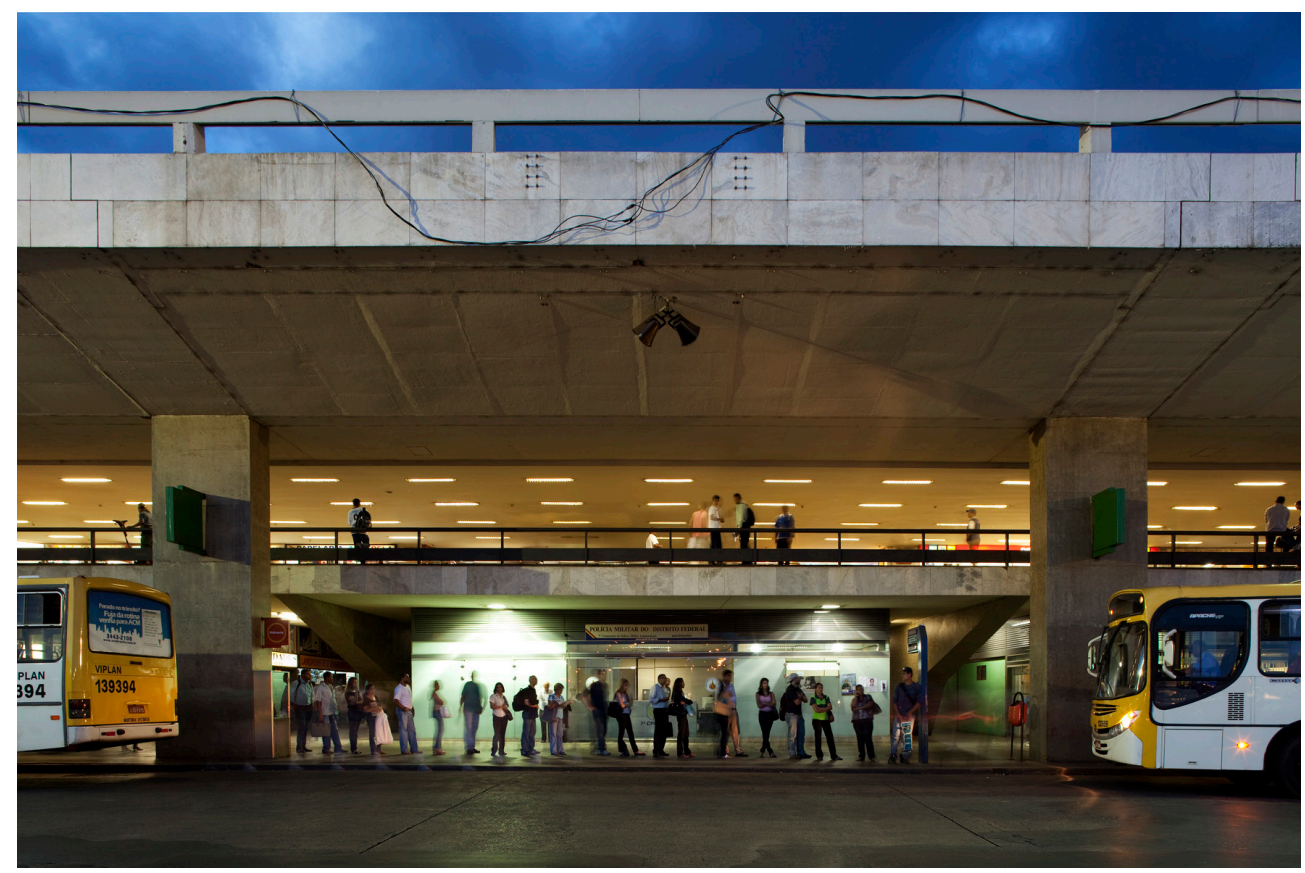

fig. 7 - Mezanino de serviços, visto a partir da cota da estação rodoviária. Fonte: Leonardo Finotti, 2010.

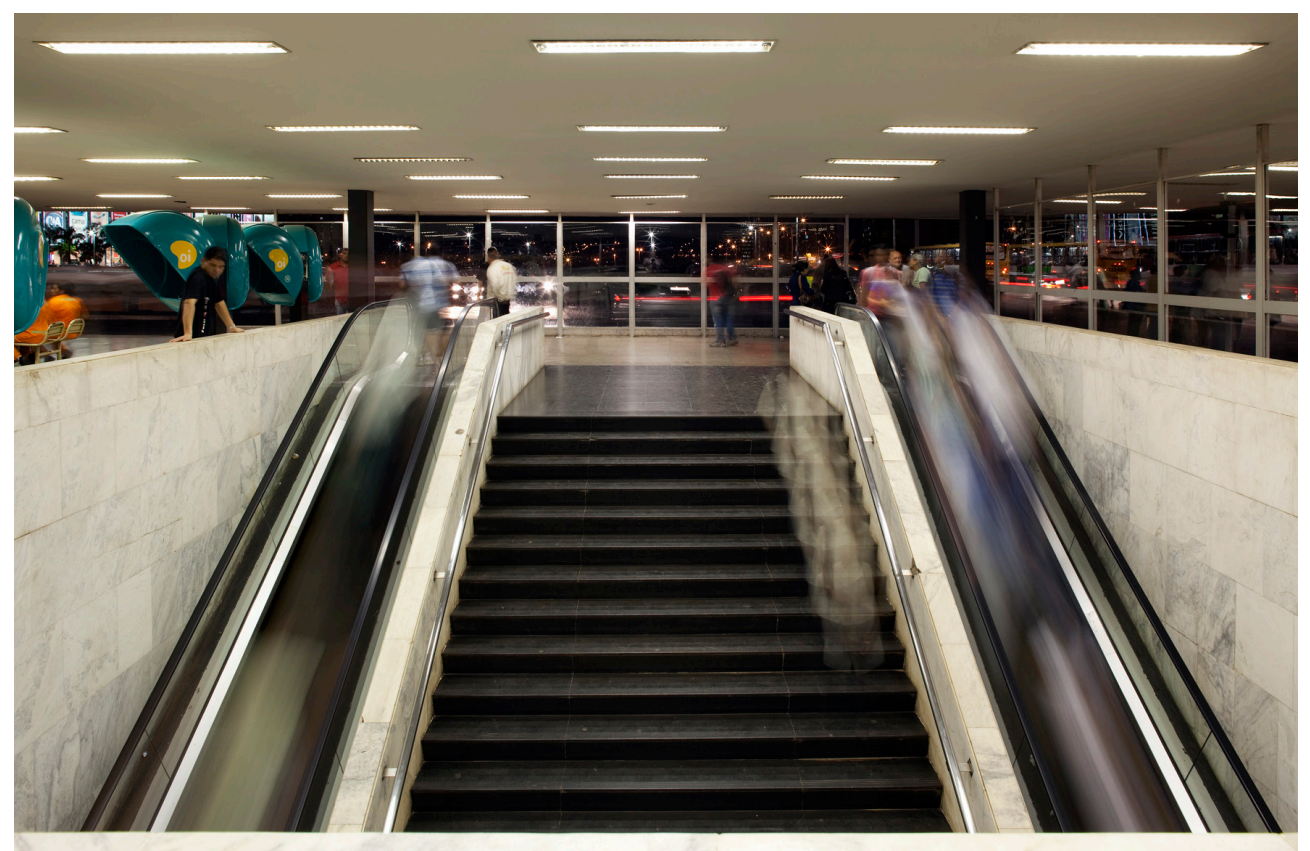

fig.8 - Conjunto de escadas de acesso ao mezanino e nível inferior. Escada Central com duas escadas mecânicas laterais, operando em sentidos opostos. Fonte: Leonardo Finotti, 2010. 
figs. 9. e $\mathbf{1 0}$ - Vistas do eixo rodoviário-residencial. Notase a sucessão de alças de conexão viária, em especial o arco à direita na imagem que permite o acesso direto aos setores hoteleiros e aos centros de diversões e é uma das alternativas à passagem pela plataforma. Há ainda, sob as lajes conexões em nível entre os eixos. Fonte: Nelson Kon, 2010 e 2007.
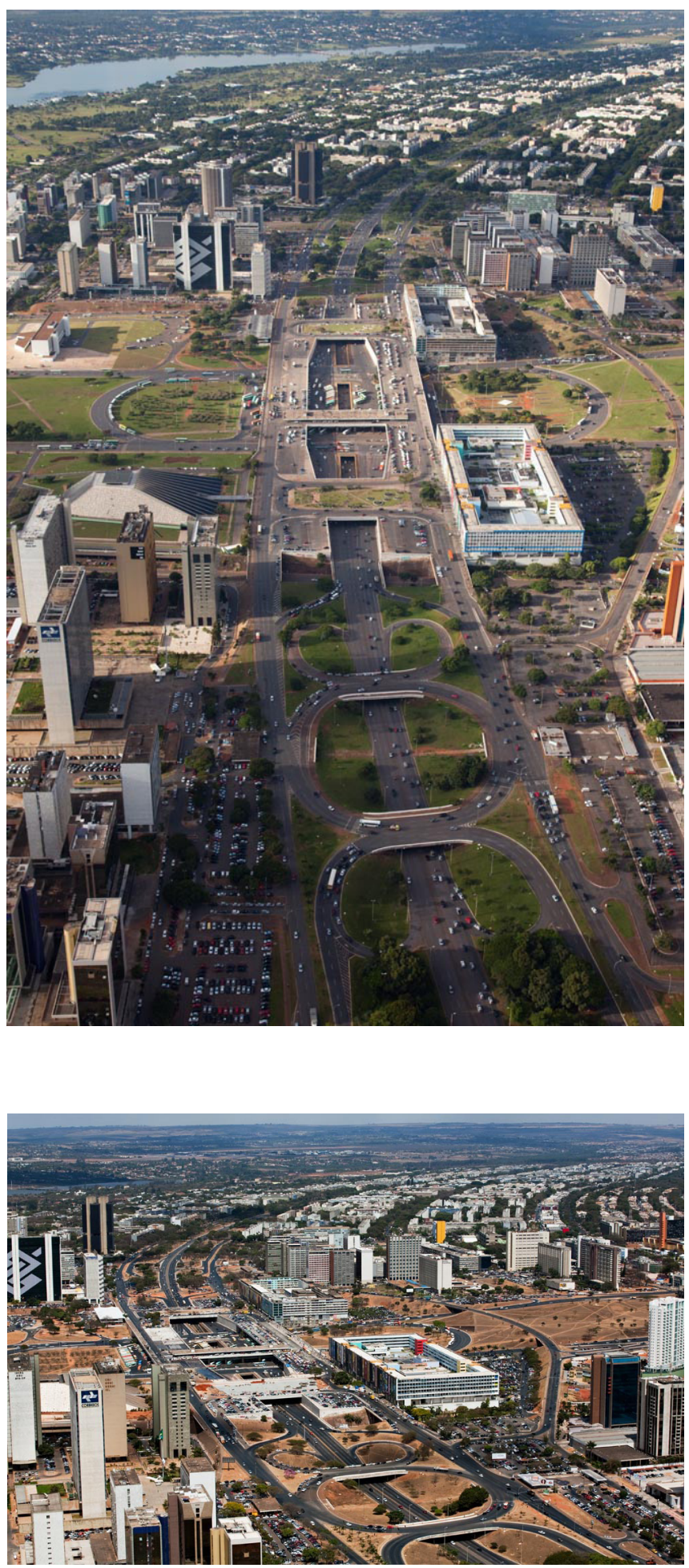
O vazio criado pelo movimento de terra, cujo excedente foi usado para criar a esplanada da praça dos Três Poderes, foi preenchido com pouca construção. Apenas o mezanino(fig. 7) faz as vezes de ponto intermediário entre os dois principais níveis e promove a descida de público através dos dois conjuntos de escadas(fig. 8). Esses conjuntos são compostos por escadas tradicionais e escadas mecânicas, que garantem o grande fluxo necessário, além de um conjunto de elevadores (ver desenhos nos encartes). As articulações verticais viárias se dão através de um engenhoso conjunto de alças e rampas que permitem tanto a passagem direta pelo conjunto, sem interrupções ou cruzamentos, como retornos e a transferência de um macroeixo a outro (figs. 9 e 10).

\section{articulação horizontal}

As principais articulações horizontais promovidas hoje pela plataforma rodoviária são as de transposição do eixo Monumental, que permitem a ligação no sentido longitudinal da estrutura (Norte-Sul), entre os conjuntos comerciais, principalmente para pedestres através do nível superior e entre as asas Norte e Sul, para veículos, pela passagem expressa subterrânea. No sentido transverso, embora seja possível a conexão, o fato de não haver articulações verticais eficientes entre as cotas dos setores a Leste ou a Oeste, faz com que o fluxo seja mínimo. Ou seja, a atividade apenas eventual do Teatro Nacional e a não conclusão do setor cultural Norte, o abandono da Casa de Chá, e a ineficiência dos edifícios dos centros de diversão em se conectar com os setores hoteleiros a Oeste, tornam essa articulação frágil. Soma-se a isso a baixa eficiência ambiental das praças projetadas entre esses grupos de edifícios, com pouca sombra e passeios estreitos.

\section{fluxos}

O nível inferior da plataforma, coincidente com o eixo monumental, abriga a função rodoviária. Predominantemente destinado ao fluxo de veículos, 


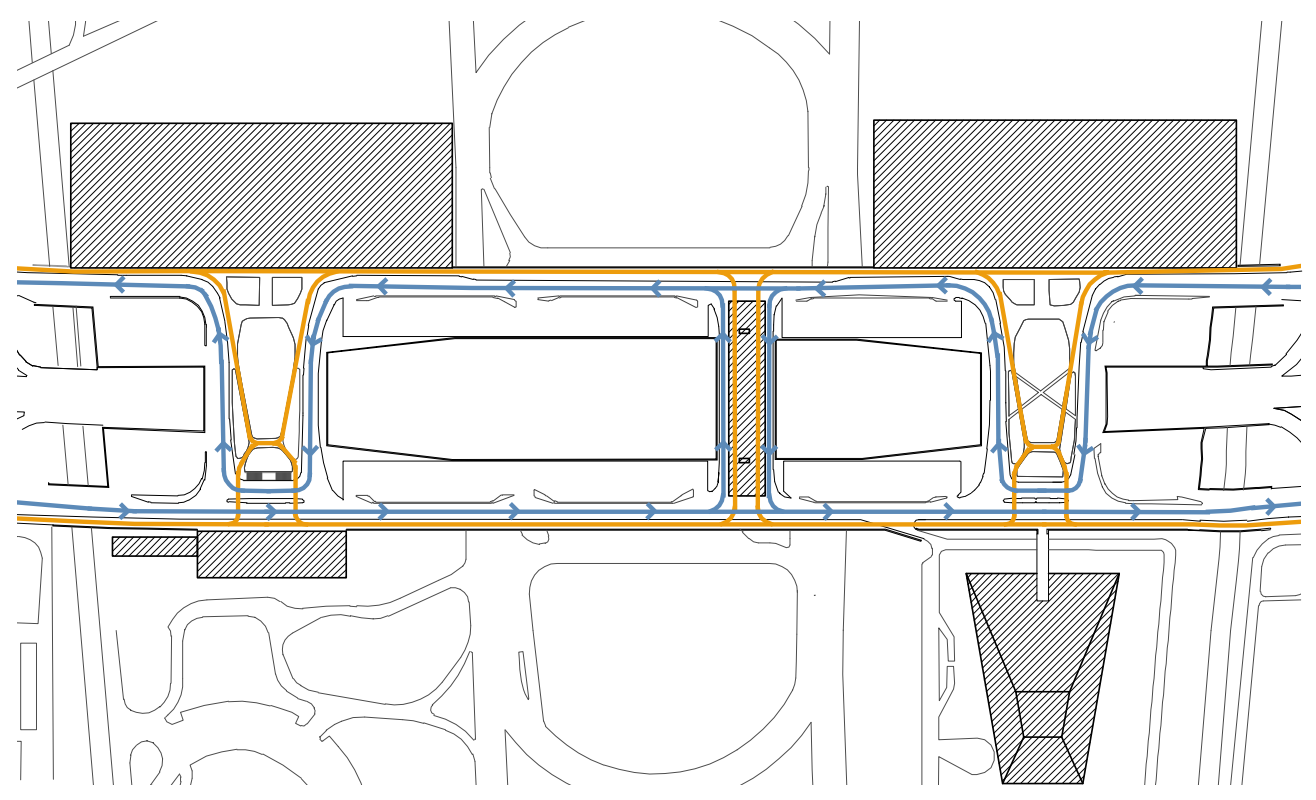

diagrama 6 - Fluxos de pedestres e veículos no nível superior da plataforma rodoviária.

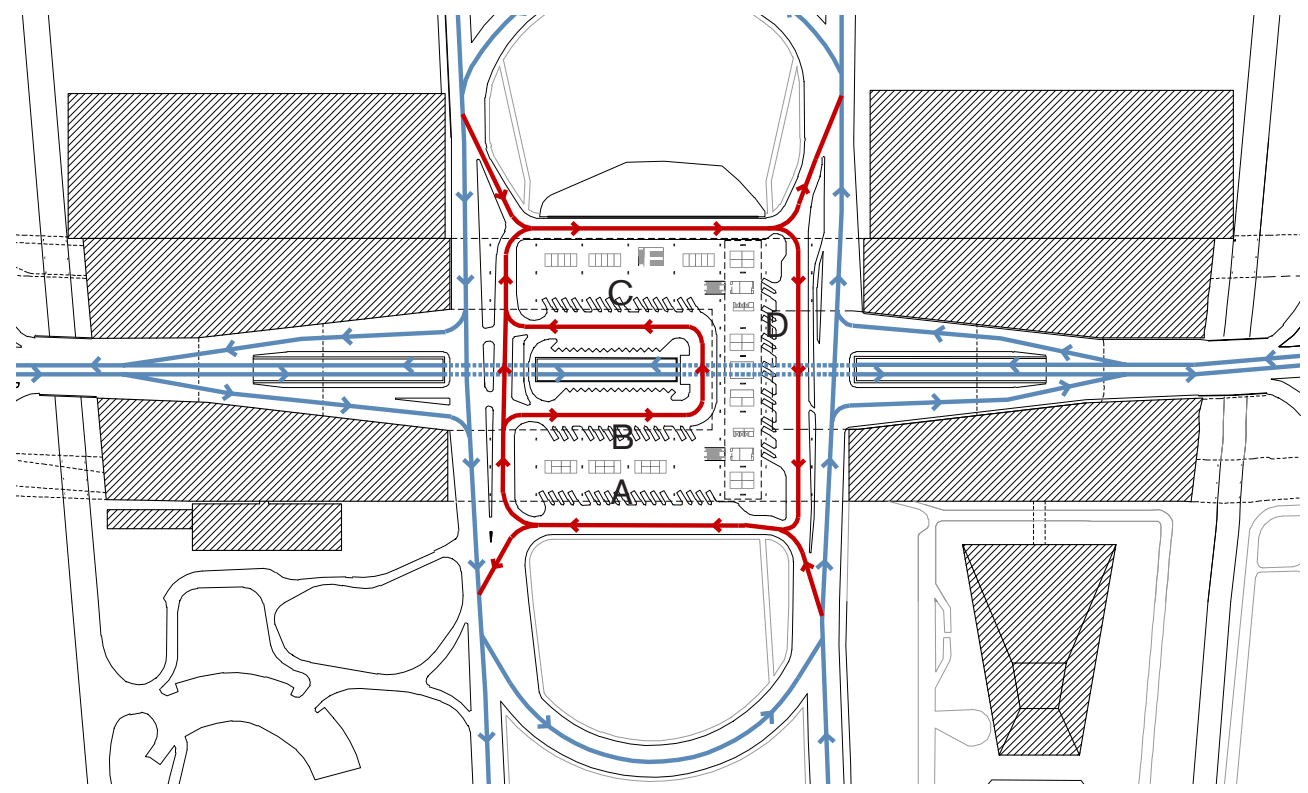

diagrama 7 - Fluxos de veículos particulares e ônibus no nível inferior, o da estação rodoviária.

Analisando os fluxos predominantes de pedestres e veículos nos níveis superior e da estação rodoviária, principais níveis do edifício e únicos onde há superposição, nota-se que enquanto na cota superior há pouca interferência mútua, o fluxo de veículos domina o nível inferior. Há poucas possibilidades de convivência. Apesar disso há um grande fluxo de pessoas que acessa a estação rodoviária por essa cota, e não pelo mezanino central, como previsto. Fruto da deficiência de articulação da cota superior com os edifícios e setores do entorno. 
apresenta no entanto conflitos com os pedestres. Há quatro plataformas de embarque e desembarque: $A, B, C$ e $D$, que atendem às linhas locais e regionais e poucos pontos de travessias de pedestres (diagrama 8 ). No entanto não há nenhum tipo de controle de acesso ou segregação entre esse espaço da plataforma e os espaços contíguos. O sistema viário segrega apenas os veículos particulares dos percursos dos ônibus.

$\mathrm{Na}$ cota superior os fluxos de veículos são interrompidos pelas praças, criando um percurso tortuoso que promove efetivamente o tráfego apenas local (diagrama 6). Apesar da aparente virtude, o conjunto de desvios reduz a área possível de embarque e desembarque em frente do Conjunto Nacional e Conic e cria do lado oposto, junto à Casa de Chá e o Teatro Nacional, uma travessia de duas mãos, com vinte metros de comprimento, inibindo ainda mais a já pouco convidativa articulação horizontal no sentido transverso. Como se vê, os fluxos de pedestres estão bastante estrangulados, apesar da generosa área e da baixa intensidade relativa de tráfego de passagem de veículos.

\section{usos do espaço da plataforma}

Uma das grandes virtudes da rodoviária e condição de seu sucesso como criadora de urbanidade é a variedade de usos e serviços que oferece. Essa intensidade, se não foi consequência da resolução adequada das articulações entre os diversos setores previstas originalmente, especialmente por inconsistências de desenho no desenvolvimento dos projetos dos edifícios do entorno, como veremos a seguir, se deu ainda assim graças a um atributo de desenho. Como já mencionado anteriormente, o tamanho dos espaços permitiu a prática de atividades muito mais diversas das tipicamente associadas a uma estação rodoviária, ainda que beneficiada pelo fluxo de pessoas promovido por sua função no sistema de transportes. Uma grande quantidade de pessoas vai à plataforma com finalidades que vão além do uso da estação de transporte público.

No nível da estação, além das pistas de rodagem há amplos espaços, 

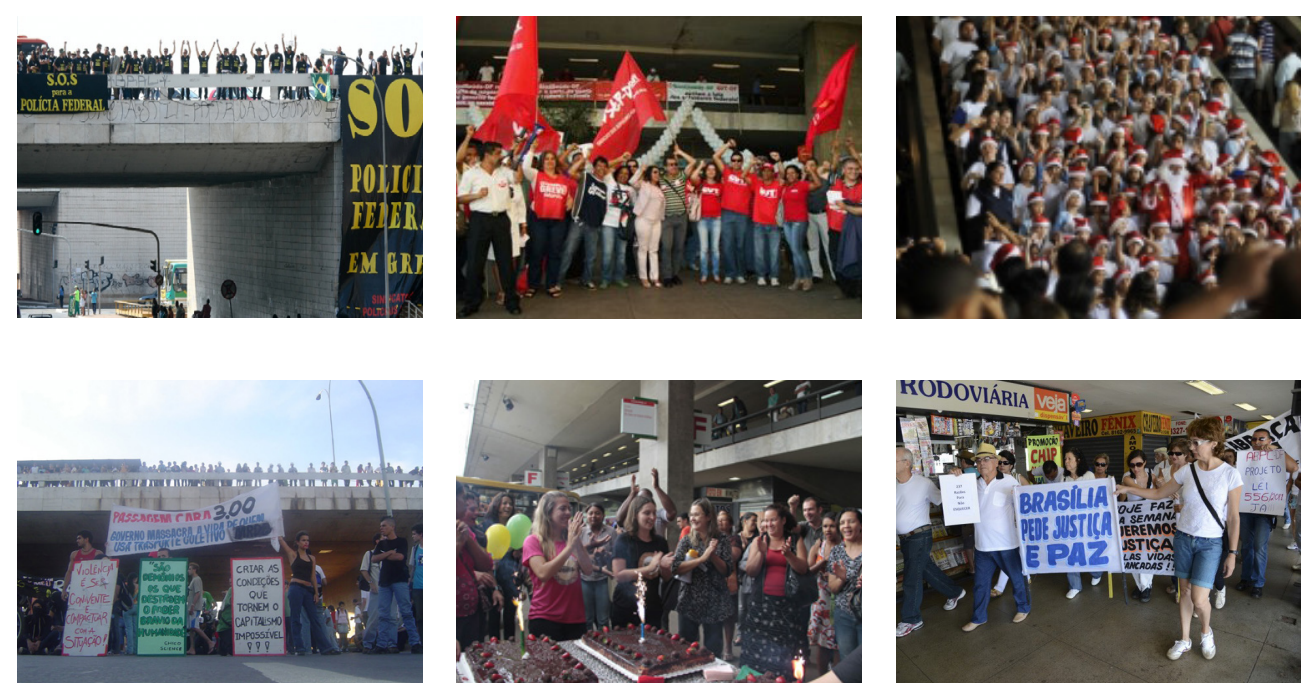

figs. 11 a 16 - É frequente o uso dos espaços da plataforma rodoviária para manifestações de toda ordem: políticas, festivas, relacionadas a direitos civis ou de classe.

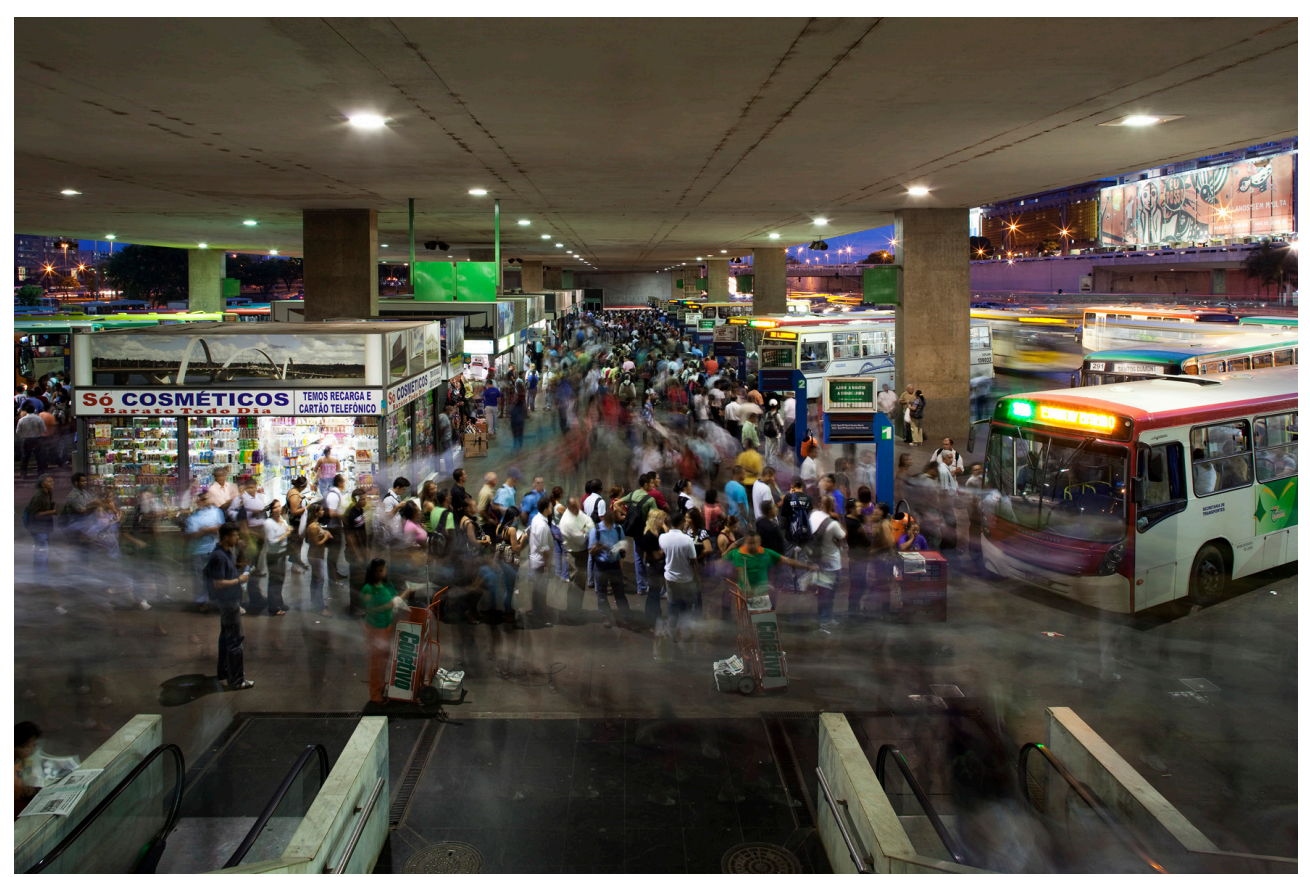

fig. 17 - Vista da plataforma da estação rodoviária vista das escadas de acesso. À esquerda vê-se um dos 66 boxes comerciais e à direita ao fundo a fachada do Conic. Fonte: Leonardo Finotti, 2010. 
com aproximadamente 30 metros de largura por 140 metros de comprimento, ou seja, 4 mil metros quadrados de área de cada lado do eixo rodoviário-residencial disponíveis para as funções de espera, embarque e desembarque de, no máximo, 45 ônibus simultaneamente. Gradativamente esses espaços foram ocupados por pequenas estruturas com as mais diversas funções. Ao longo do tempo foram sendo utilizados para atividades de comércio formal e informal e abrigam alguns locais muito populares e tradicionais em Brasília, como o que vende pastéis e caldo de cana. Somadas as áreas sob e sobre o mezanino, sob a marquise e do acesso à estação de metrô, são quase 5 mil metros quadrados dedicados a serviços públicos e comércio. Existem 66 boxes comerciais; 3 conjuntos de sanitários públicos masculinos e femininos; um posto da polícia militar, uma delegacia da polícia civil, agência de correios, posto de informação ao trabalhador, agência da caixa econômica federal, agências das concessionárias de serviços públicos, como energia elétrica e abastecimento de água e telefonia, posto de saúde, com exames gratuitos, e o sistema de expedição de documentos "Na Hora", com áreas de atendimento ao público de diversas autarquias governamentais.

Mas além dos usos formais, é sintomático de seu alto grau de urbanidade a apropriação informal de seus espaços. Lá são realizadas frequentemente diversas manifestações políticas ou promocionais. O nível superior da plataforma foi até 2008 ocupado diariamente por uma grande aglomeração de vendedores ambulantes, que foram removidos à força para um local isolado, construído para esse fim pelo governo do Distrito Federal.

Há diversos relatos, inclusive de Lucio Costa, que colocam esse espaço em Brasília como o lugar em que se tornam visíveis as atividades e pessoas que não habitam os ambientes burocráticos ou residenciais previstos no Plano Piloto e que no entanto fazem parte de sua existência. 


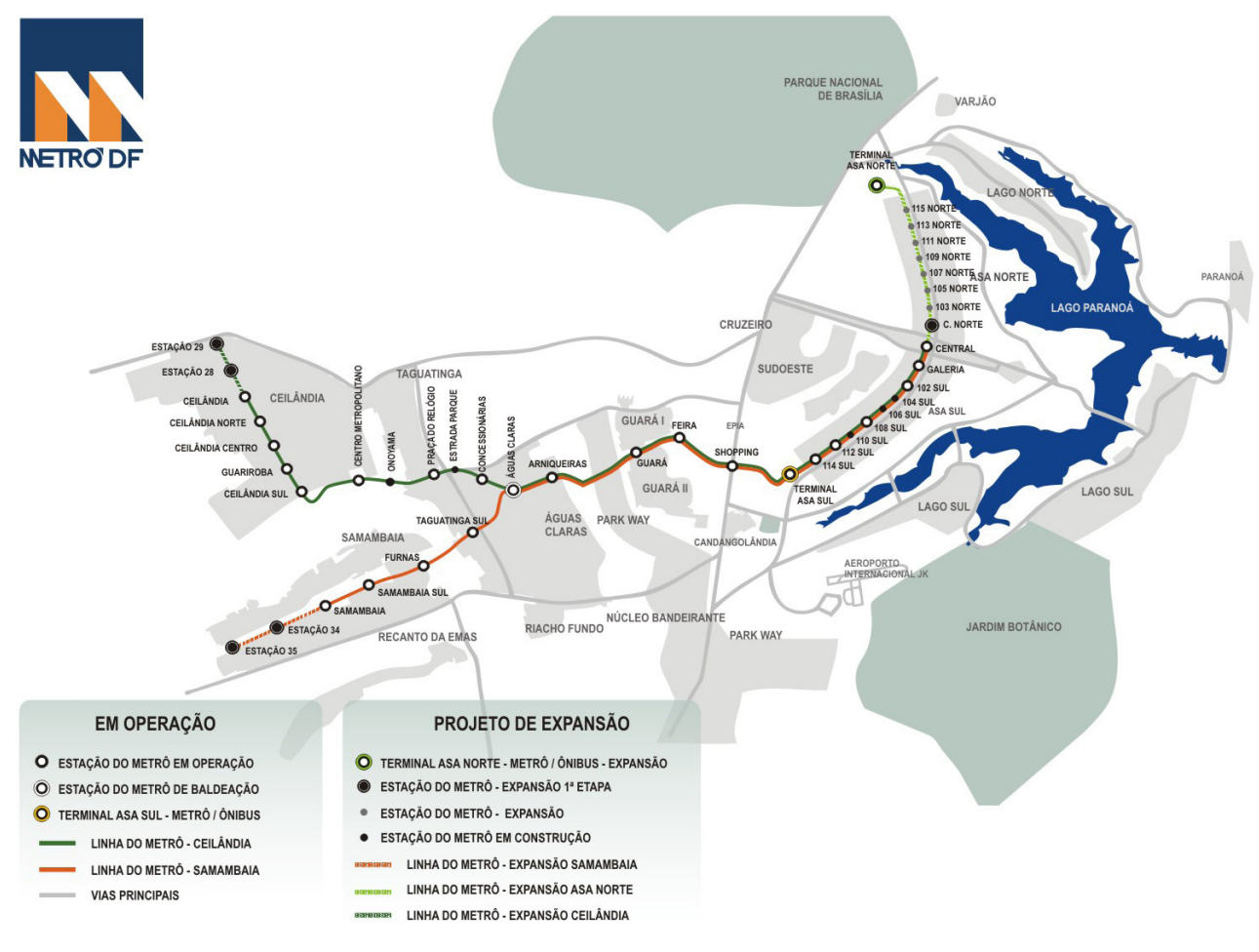

fig. 18 - Sistema de Metrô alcançará grande parte da região metropolitana de Brasília. Fonte: Companhia do Metropolitano do Distrito Federal

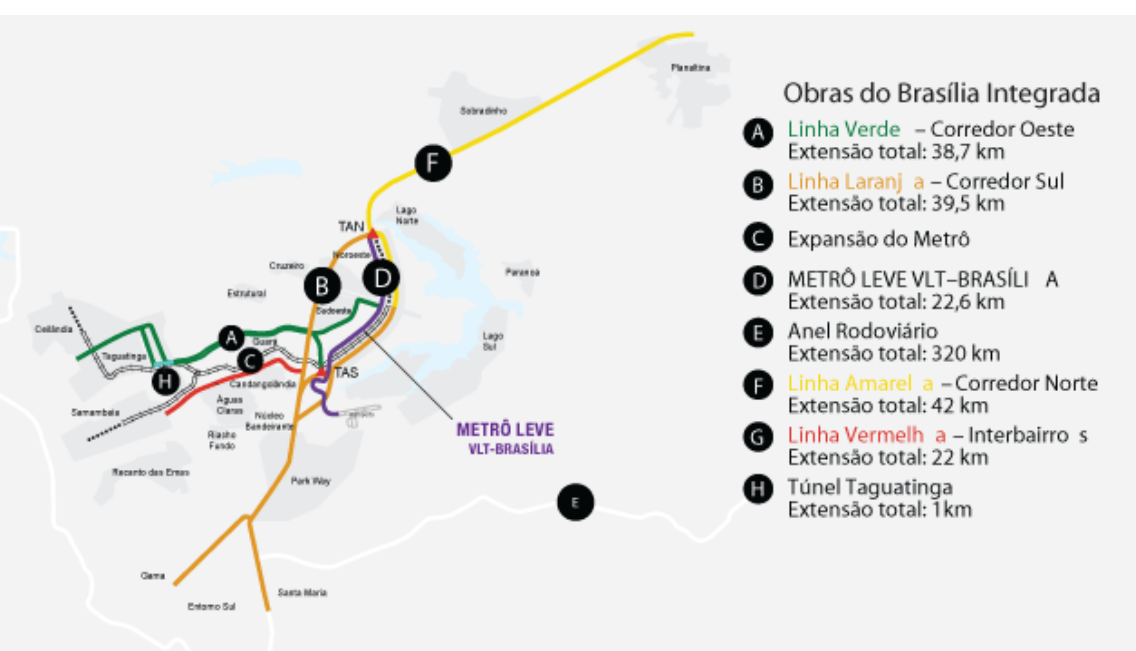

fig. 19 - Sistema de integrado, com VLT. Fonte: Companhia de Metrô do Distrito Federal 


\section{b. infraestrutura: a performance da plataforma dentro do sistema mobilidade de Brasília}

A plataforma rodoviária é o principal nó articulador do sistema de transporte público da região metropolitana de Brasília (fig. 18). Esse sistema é composto principalmente por um conjunto de linhas de ônibus urbanos e por duas linhas de Metrô, que têm na plataforma o principal ponto de conexão. A partir de 2015, uma linha de VLT complementará o sistema.

Passam pela plataforma rodoviária a maior parte das mais de 880 linhas de ônibus em operação na cidade, que conta com uma frota de aproximadamente 2.300 ônibus convencionais, além de vans e micro-ônibus. Estima-se que passem por lá diariamente 500 mil pessoas. (fonte: Site do DFTrans, acessado em jan de 2013). Desde 1976, quando a operação das linhas de ônibus interestaduais foi transferida para a Estação Ferroviária, nunca utilizada como tal, a $6 \mathrm{~km}$ a Oeste, no arremate do eixo monumental, a plataforma rodoviária passou a ser o centro do sistema de ônibus da área metropolitana, composta não só pelas cidades satélites do Distrito Federal mas também pelas cidades do entorno.

É pela plataforma rodoviária que se dá o acesso à estação central do Metrô de Brasilia desde 2001, com a entrada em operação plena do sistema, que atende atualmente aproximadamente 130 mil pessoas por dia através de suas 24 estações e $42 \mathrm{~km}$ de extensão. (Fonte: Companhia do Metropolitano do Distrito Federal http://www.metro.df.gov.br/sobreo-metro/memoria.html) (fig. 18). Grande parte desses usuários utiliza a plataforma como chegada ao setor central de Brasilia, em que há uma grande concentração de postos de trabalho, ou como estação de integração com as linhas de ônibus locais, o que mostra como ela funciona como um grande ponto de conexão de fluxos.

O VLT (veículo leve sobre trilho), ainda em construção, deverá correr paralelo ao percurso do Metrô, e complementará o sistema, ligando o aeroporto ao eixo rodoviário-residencial, correndo pela W3. (fig. 19) . Embora não haja a previsão de uma articulação direta com a plataforma, o VLT deverá impactar em seu funcionamento, na medida em que aumentará a 


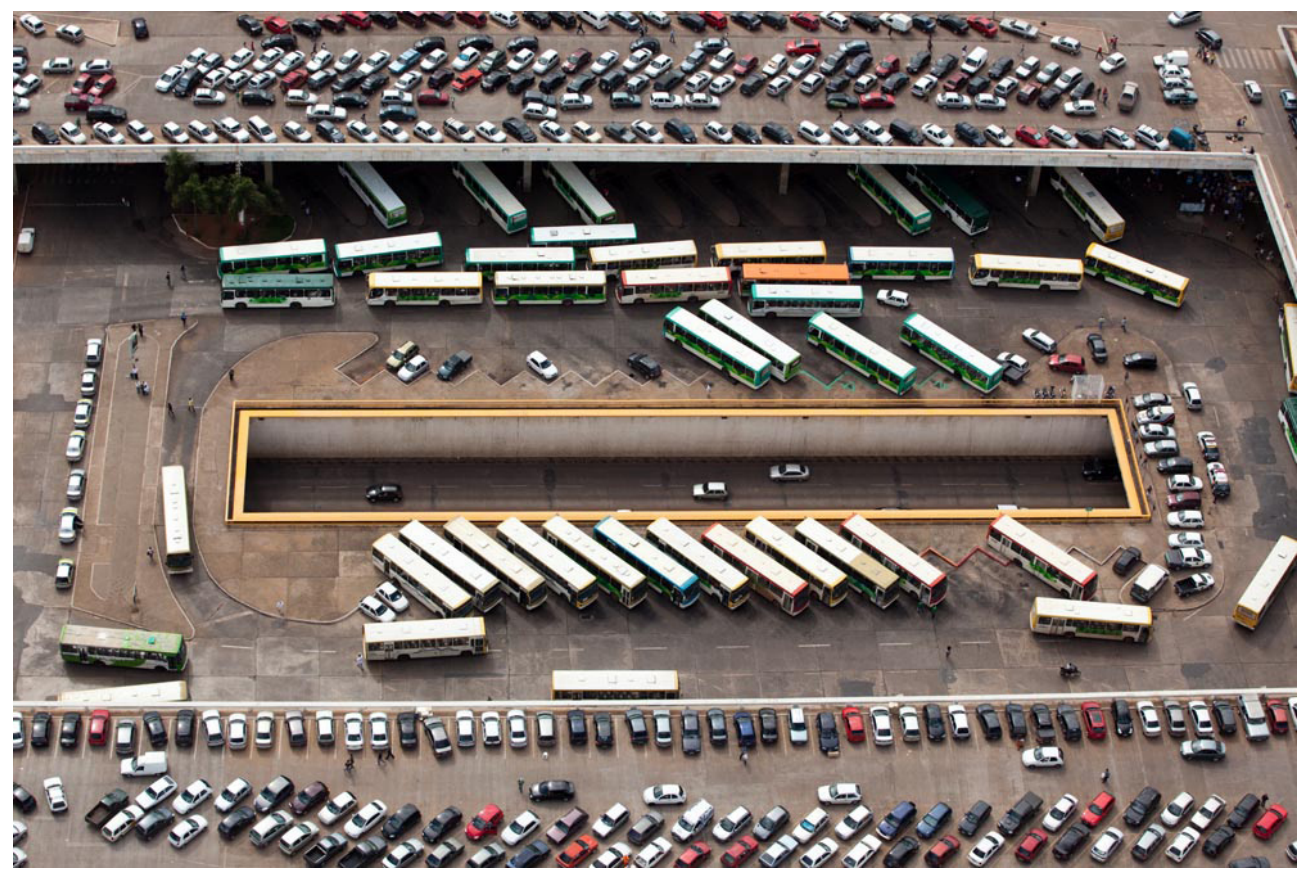

fig. 20 - Vista aérea da plataforma. Em primeiro plano o nível superior ocupado plenamente por veículos particulares como estacionamento. No plano inferior os ônibus urbanos e as plataformas de embarque. Ao centro as vias expressas do eixo rodoviário-residencial. Fonte: Nelson Kon, 2010. 
oferta de transporte e a eficiência de fluxo do eixo norte-sul, atualmente congestionado.

Essa função de "entrada" e conexão é especialmente relevante para o funcionamento de Brasília se considerarmos que cerca de 700 mil pessoas circulam por dia na área do Plano Piloto, que conta com apenas 215 mil do total de aproximadamente 2,5 milhões de habitantes do Distrito Federal. Ou seja, mais de três vezes a sua população do Plano Piloto vem diariamente de fora de seus limites, e duas vezes o total de sua população passa pela plataforma rodoviária diariamente. (fonte: Codeplan - Companhia de planejamento do distrito federal -http://www.codeplan. df.gov.br/menu-de-teste/informacoes-estatisticas/cat_view/262-informacoes-estatisticas/263-anuario-estatistico-/322-anuario-estatistico-do-df2012.html)

Outra articulação importante promovida pela plataforma é com o sistema de transporte individual. Além de realizar com seus retornos e transposições de nível a conexão viária entre os macro-eixos monumental e rodoviário-residencial, a plataforma hoje dá acesso e abriga parte considerável das áreas de estacionamento do setor central. Considerando que a frota de veículos particulares do DF já era de um milhão em 2008, com aproximadamente um veículo para cada 2,4 habitantes, e que $88,8 \%$ dos habitantes do Plano Piloto tem ao menos um veículo em seu domicílio, (fonte: Pesquisa Distrital por Amostra de Domicílios (Pdad) divulgado pela Companhia de Planejamento do Distrito (Codeplan) em 2012), não é irrelevante a função de estacionamento para o sistema geral de transportes. Há atualmente aproximadamente 15 mil vagas no setor central e estimam-se necessárias outras 30 mil.

São números que refletem a importância estratégica e a eficiência da plataforma no funcionamento do sistema de mobilidade da cidade, integrando as redes e oferecendo o espaço de acesso ao grande fluxo diário de pessoas que frequentam o Plano Piloto. Internamente, a organização de embarques e desembarques se realiza graças à generosidade de seus espaços e à grande dimensão de suas áreas cobertas, que permitem a convivência de inúmeras atividades, compartilhando serviços e acessos. 


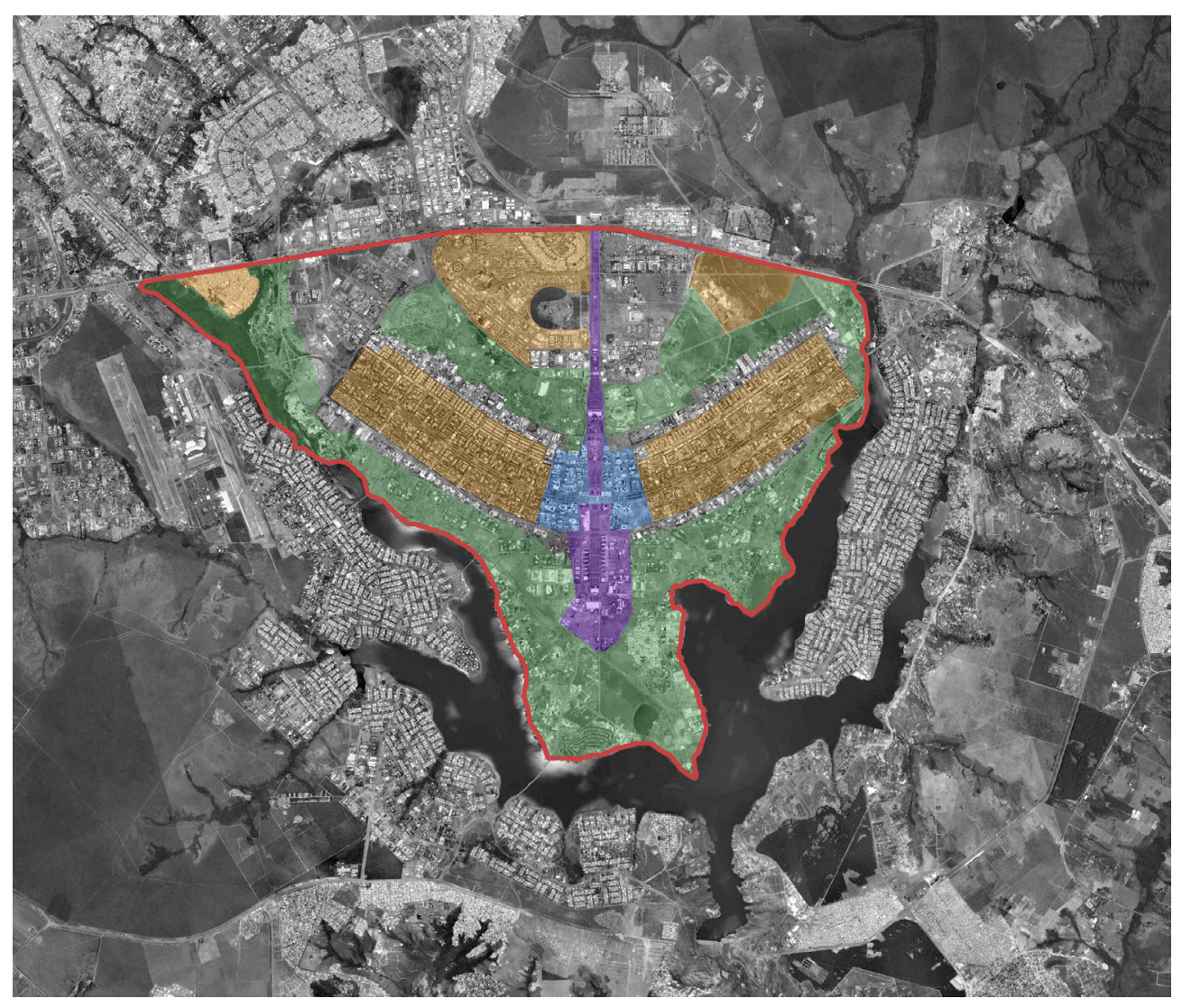

fig. 21 - A imagem mostra a localização das escalas dentro da área de demarcada (perímetro em vermelho) segundo decreto de 1987 acerca preservação da concepção urbanística de Brasília. Em verde, a escala bucólica, em amarelo, a escala residencial, um roxo a escala monumental e por fim, ao centro, em azul a escala gregária, que articula as demais. Fonte: Instituto do Patrimônio Histórico e Artístico Nacional (IPHAN). 


\section{c. papel da plataforma como articulação do centro de Brasília}

A plataforma desempenha um importante papel na conexão dos espaços do que veio a se chamar de escala gregária do Plano Piloto. Embora o termo escala não apareça no Relatório do Plano Piloto (Costa, 1995), o conceito foi ganhando relevância como forma de explicar a estrutura funcional de Brasília. Sem adotar os termos próprios das zonas funcionais do urbanismo moderno, o Plano Piloto organizou-se em quatro escalas. Em 1974, no I Seminário de Estudos dos Problemas Urbanos de Brasília, Lucio Costa comenta que às três escalas até então mencionadas "se acresce uma quarta, pois, no fundo, as três situações, como os Três Mosqueteiros, são quatro (Risos): a escala gregária, a monumental, a cotidiana e a bucólica." (Senado Federal, 1974)

Embora a escala bucólica, relativa às áreas verdes, a escala residencial, em que principalmente se implantam as superquadras residenciais, e a monumental, com os edifícios e espaços cívicos da capital, não indiquem usos exclusivos, e sim predominâncias de uso, é na chamada escala gregária que se concentram de modo intenso as atividades relativas à socialidade da cidade, como centros de compras, cinemas, as sedes de empresas etc.

Como se vê no diagrama ao lado (fig. 21) a plataforma rodoviária é central às áreas da escala gregária que, como determina o Decreto 10.829, Art. 7o, que define o tombamento de Brasilia, é composta pelos setores Comercial (1), Bancário (2), de Diversões (3), Hoteleiros (4), MédicoHospitalares (5), de Autarquias e de Rádio (6) e Televisão (7), a Norte e a Sul do Eixo Monumental. Com suas passagens pedestres e viárias, a construção conecta, embora atualmente de modo muito precário, esses setores entre si proporcionando passagens nos sentidos Leste-Oeste e Norte-Sul, sobre os macro-eixos estruturadores. Além dessa conexão entre os setores da escala gregária, a plataforma promove a conexão com o Setor Cultural (8), que integra formalmente a escala Monumental, mas que coerentemente se liga às áreas de socialidade, por sua vocação como espaço de concentração de pessoas em torno a atividades que 


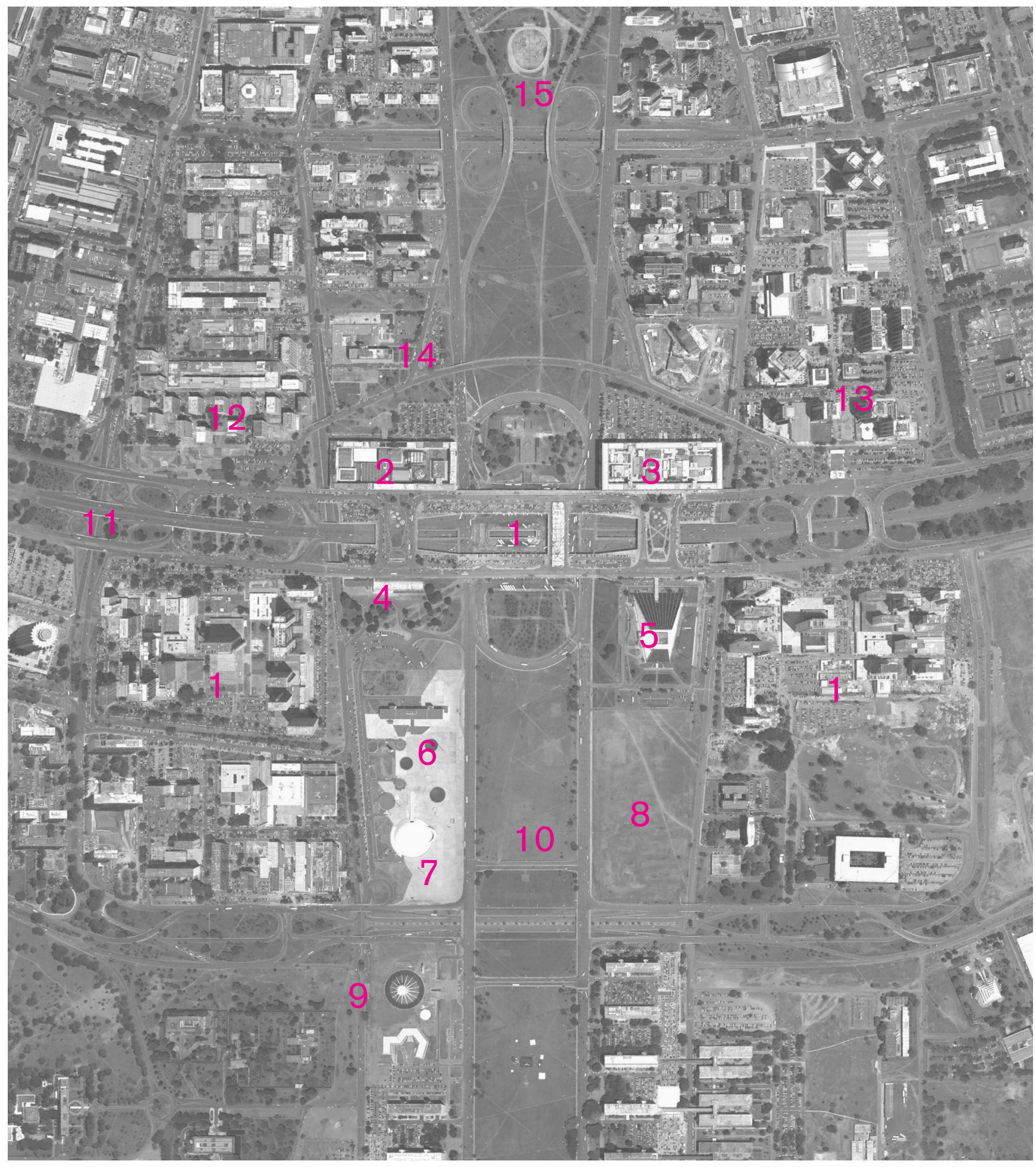

fig. 22 - Escala gregária

1 Plataforma rodoviária

2 Conic

3 Conjunto nacional
4 Casa de chá

5 Teatro nacional

6 Biblioteca nacional

7 Museu da república
8 Futura Arena Multiuso

9 Catedral de Brasília

10 Eixo monumental

11 Eixo rodoviário
12 Setor comercial sul

13 Setor comercial norte

14 Hotel nacional

15 Torre de rádio e tv 
promovem o encontro e convivência.

No entorno imediato da plataforma, conectados à cota superior, de uso predominantemente peatonal, há quatro edifícios importantes, que teriam suas funções potencializadas se a continuidade dos fluxos de pedestres fosse mais eficiente. Esses edifícios também poderiam desempenhar um papel mais ativo na articulação entre os setores bancário, comercial e hoteleiro e cultural, caso colaborassem com a transposição dos desníveis entre os eixos Monumental e Rodoviário residencial, incorporando em seu interior rotas públicas alternativas ao conjunto de escadas da plataforma rodoviária propriamente dita. 


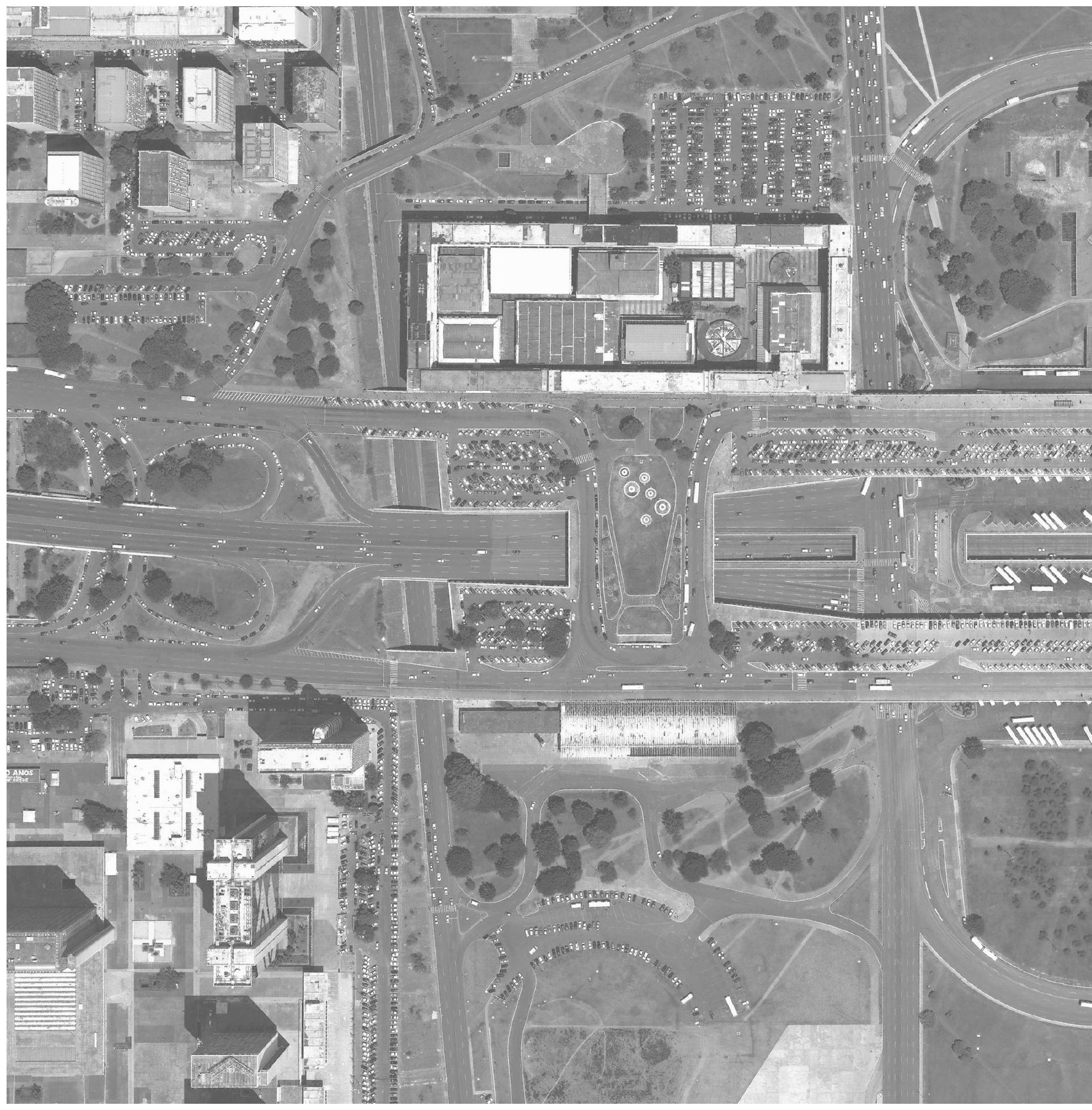

fig. 23 - Foto aérea da plataforma rodoviária de Brasília. Fonte: Google Earth, 2010. 


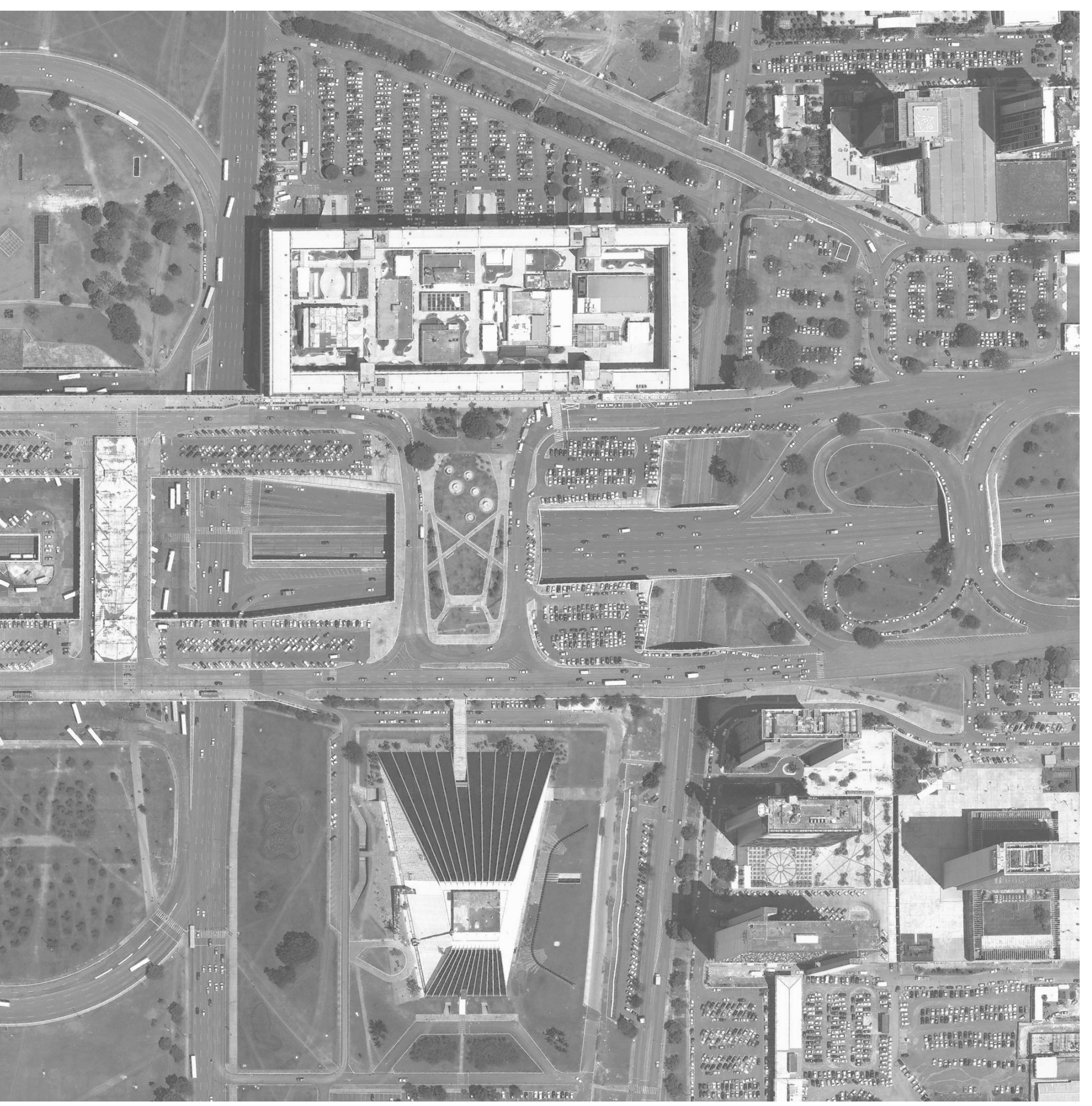



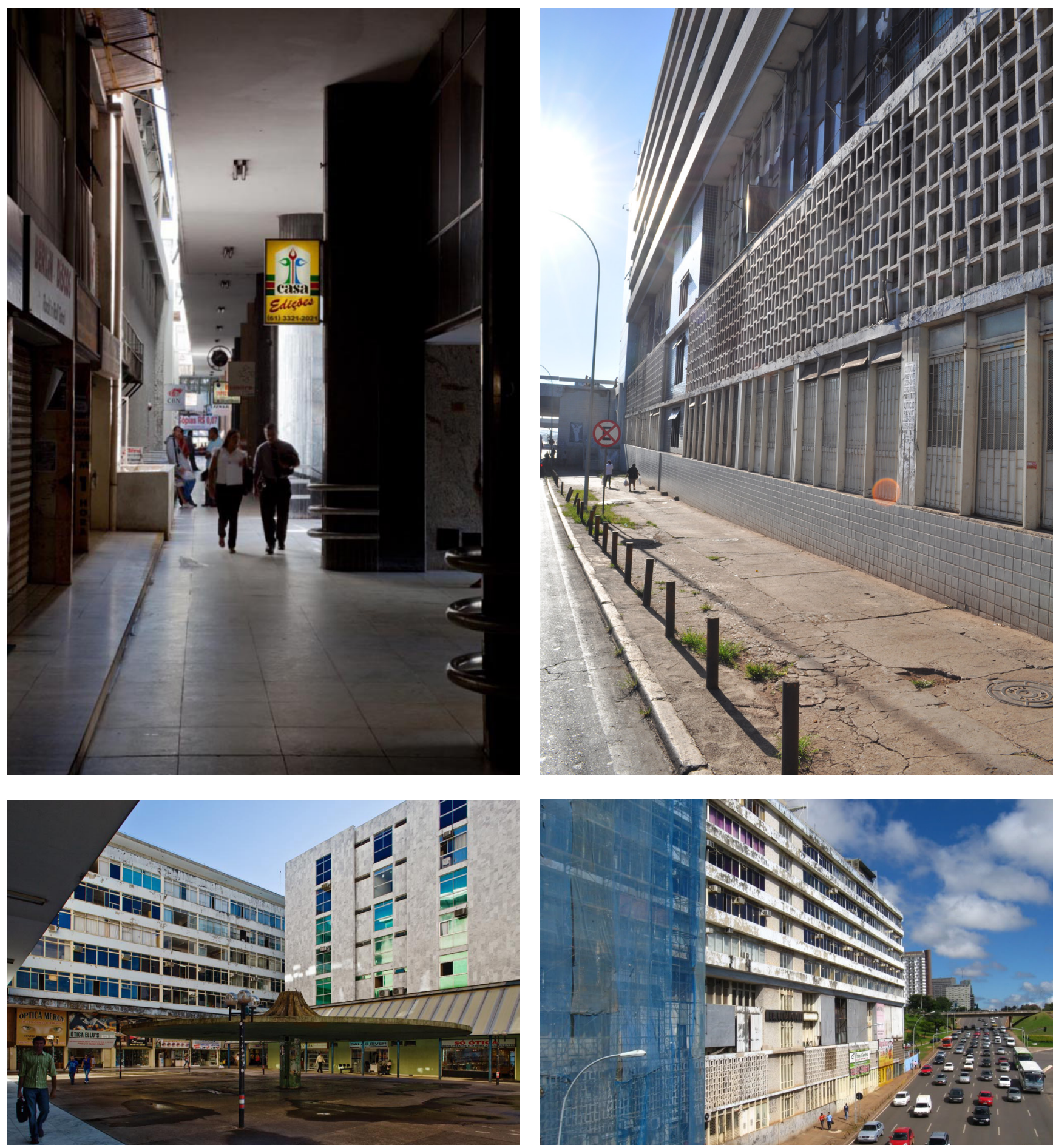

figs. 24 e 25 - Imagens dos espaços interiores do Conic. Fonte: Nelson Kon, 2010.

figs. 26 e 27 - Imagens dos espaços exteriores do Conic. Fonte: fotos do autor, 2012. 


\section{Lado Oeste - Conjunto Nacional e Conic}

Os dois grandes centros comerciais, o Conjunto Nacional a Norte e o chamado Conic, a Sul do eixo Monumental, apesar de terem formalizações bastante diversas, apresentam pouca permeabilidade tanto em seu acesso no nível superior da plataforma, predominantemente destinado a pedestres, como em seu acesso do lado oeste, na face voltada aos setores hoteleiros. Configuram dois blocos construídos com 250 metros de extensão cada, junto à plataforma, e aproximadamente 90 metros de extensão no sentido do eixo monumental. Ambos têm a altura equivalente a sete pavimentos, se considerada a partir do nível superior da plataforma.

A face Oeste do Conic, bloco comercial composto de vários edifícios justapostos, voltada à Praça dos Aposentados, adquiriu um sentido de fundos: há poucos serviços ou espaços comerciais instalados no nível do térreo, há um bolsão de estacionamento e é usada como área de carga e descarga. Por ali, os acessos ao interior do conjunto são limitados e pouco utilizados, há apenas três. O pedestre que vem do hotel Nacional ou do bolsão de estacionamento não tem clareza do percurso a se percorrer para alcançar o nível superior da plataforma. Não há conexões visuais diretas ou circulação vertical eficiente no interior do bloco construído apesar do desnível considerável, de aproximadamente 7 metros, tornando a conexão entre o lado Oeste e a plataforma bastante descontínua. O fluxo pedestre deve desviar-se para as estreitas calçadas laterais, áridas e desagradáveis. (figs. 26 e 27) Mesmo na face Leste, voltada para a plataforma, os acessos são pouco generosos e não chegam a criar continuidade espacial ou visual no sentido transverso à plataforma. No entanto, mesmo com todos os percalços em sua materialização, o Conic abriga um conjunto de atividades muito variado e rico. Sua degradação quase que simultânea à construção permitiu a instalação de boates de strip-tease, livrarias, cinemas de filmes pornográficos e cineclubes, bares, pequenos escritórios de todo tipo, em uma diversidade que se não lembra Picadilly Circus, realiza de algum modo o Soho londrino dos anos 80.

No lado Norte ocorre situação espacial análoga, embora o Conjunto Na- 


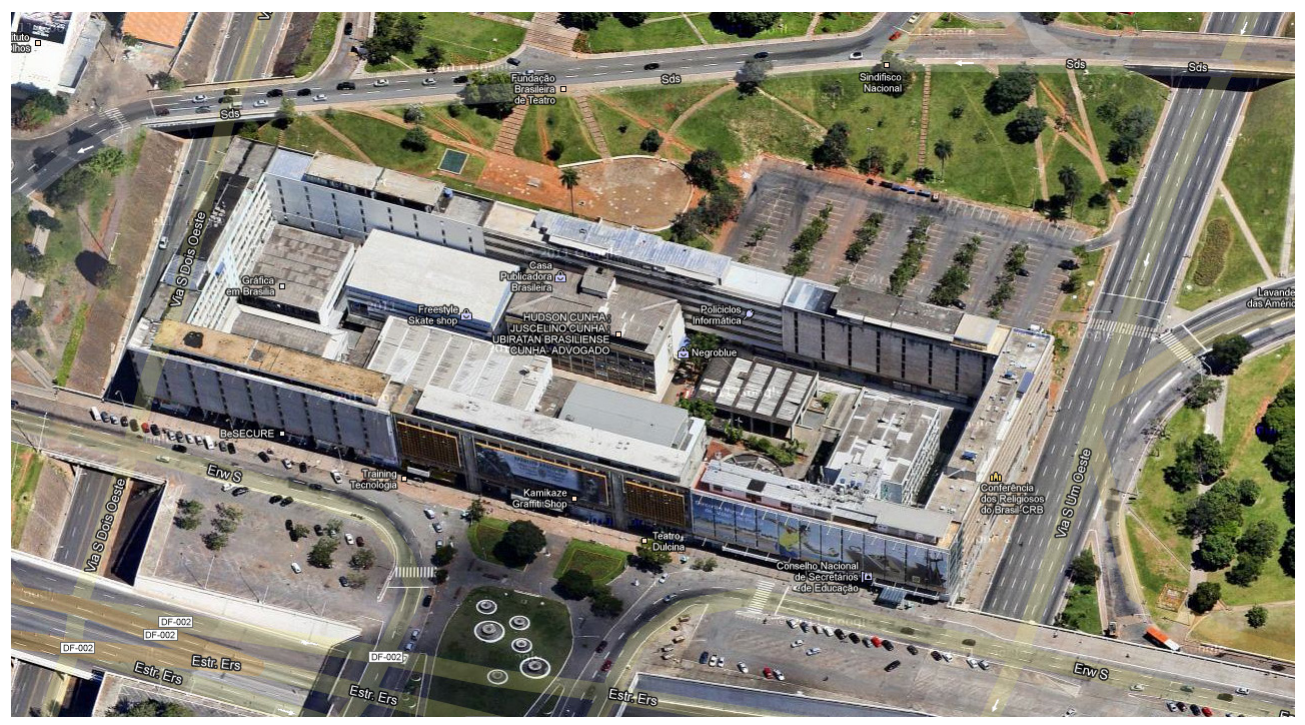

fig. 28 - Fachada frontal do Conic. Nota-se a estrutura composta por oito edifícios periféricos e dez volumes internos e a fachada frontal descontínua. Fonte: Google Maps, 2012.

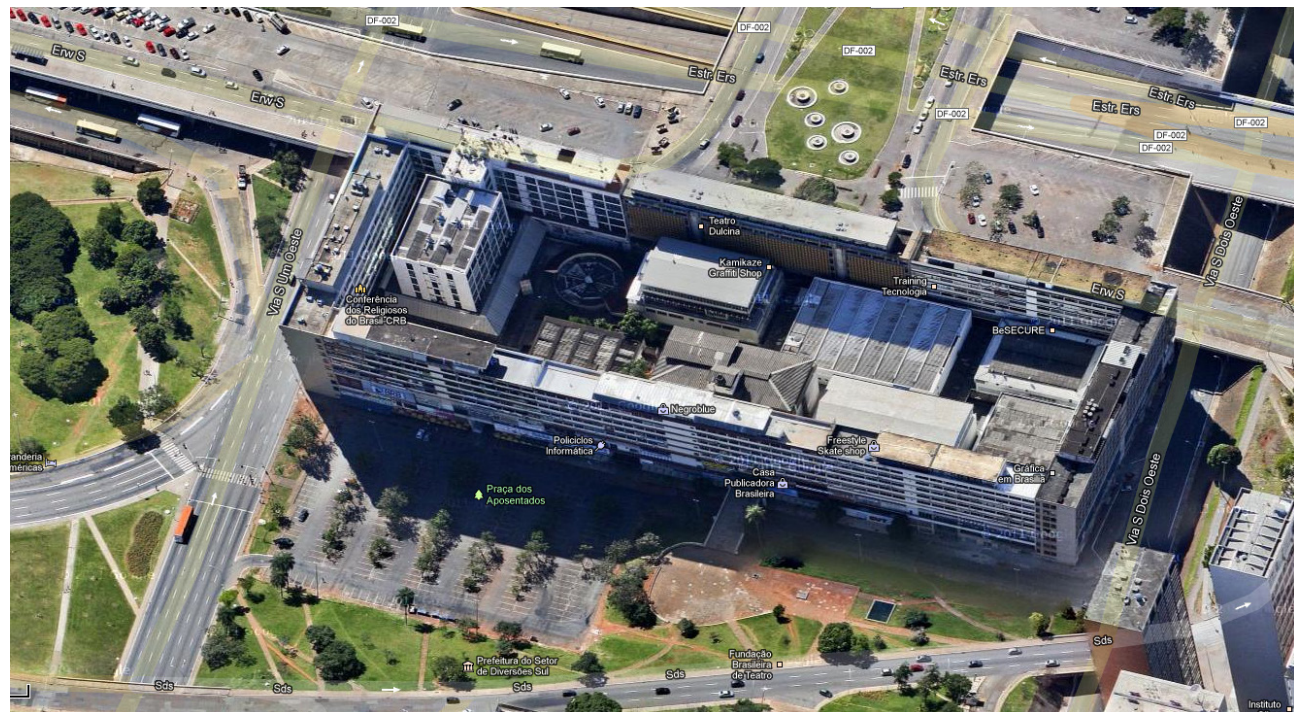

fig. 29 - Fachada posterior do Conic. Nota-se aqui a Praça dos aposentados, que promove a conexão com o nível superior do lado Oeste, embora muito precária. Nota-se como o acesso ao interior do conjunto é escasso. Fonte: Google Maps, 2012. 


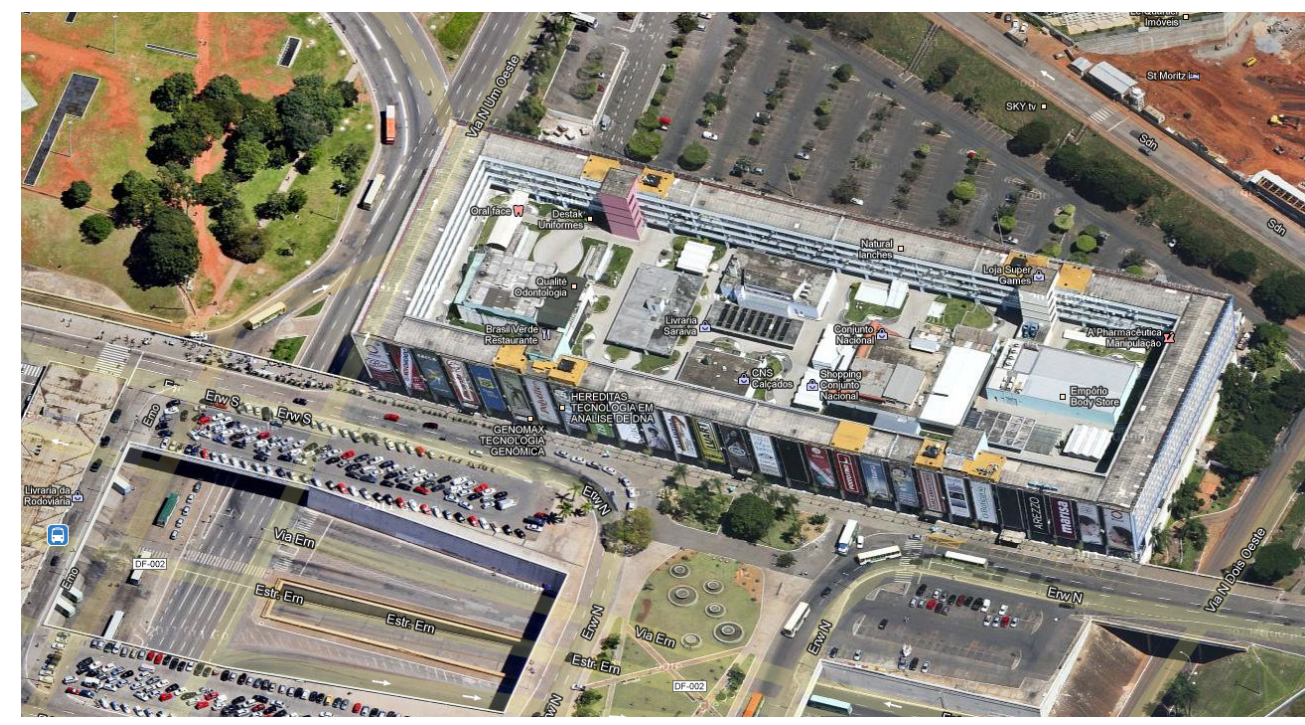

fig. 30 - Fachada frontal do Conjunto Nacional. Nota-se a fachada modulada com os "letreiros luminosos" previstos por Costa. Apresenta a mesma estrutura espacial do Conic, com um anel edificado periférico. No entanto nota-se aqui o nível do piso interior elevado em relação ao acesso pela plataforma. Fonte: Google Maps, 2012.

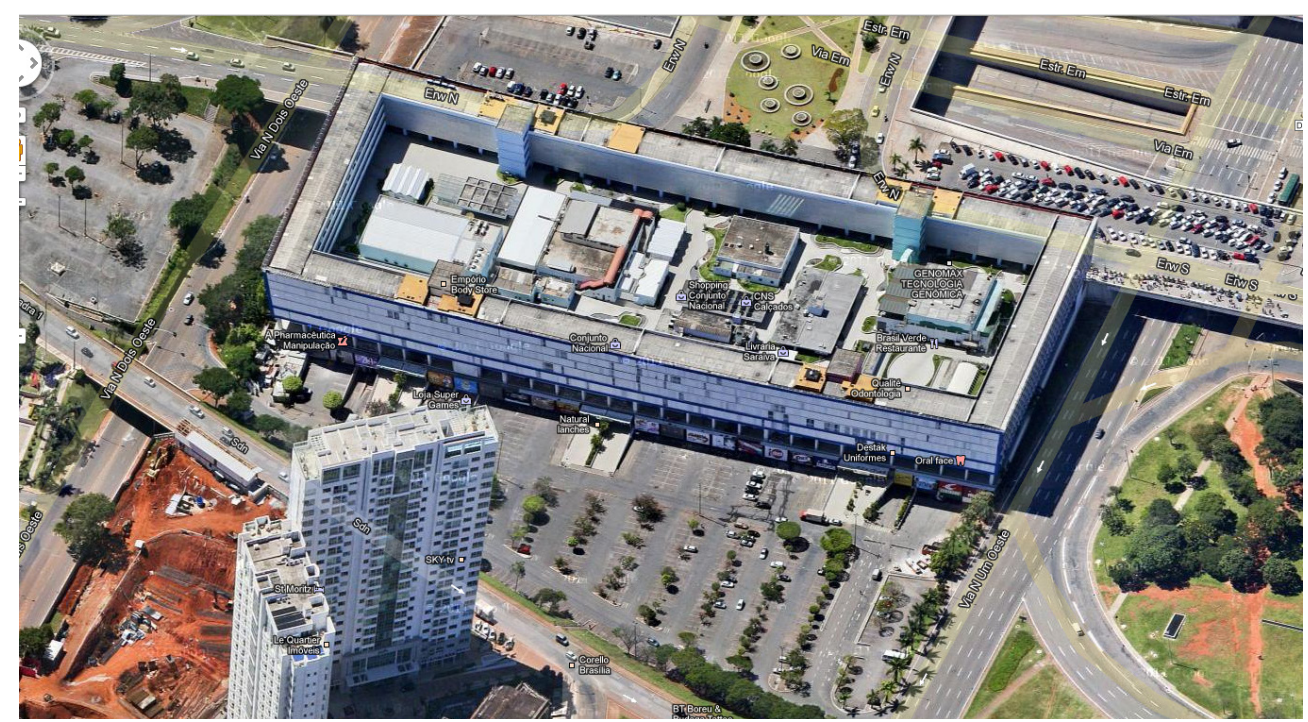

fig. 31 - Fachada posterior do Conjunto Nacional. Aqui vê-se a galeria, elevada em relação ao passeio público nesta fachada, criando um embasamento ao conjunto. Os acessos são mais evidentes e em maior número que os do Conic.. Fonte: Google Maps, 2012. 

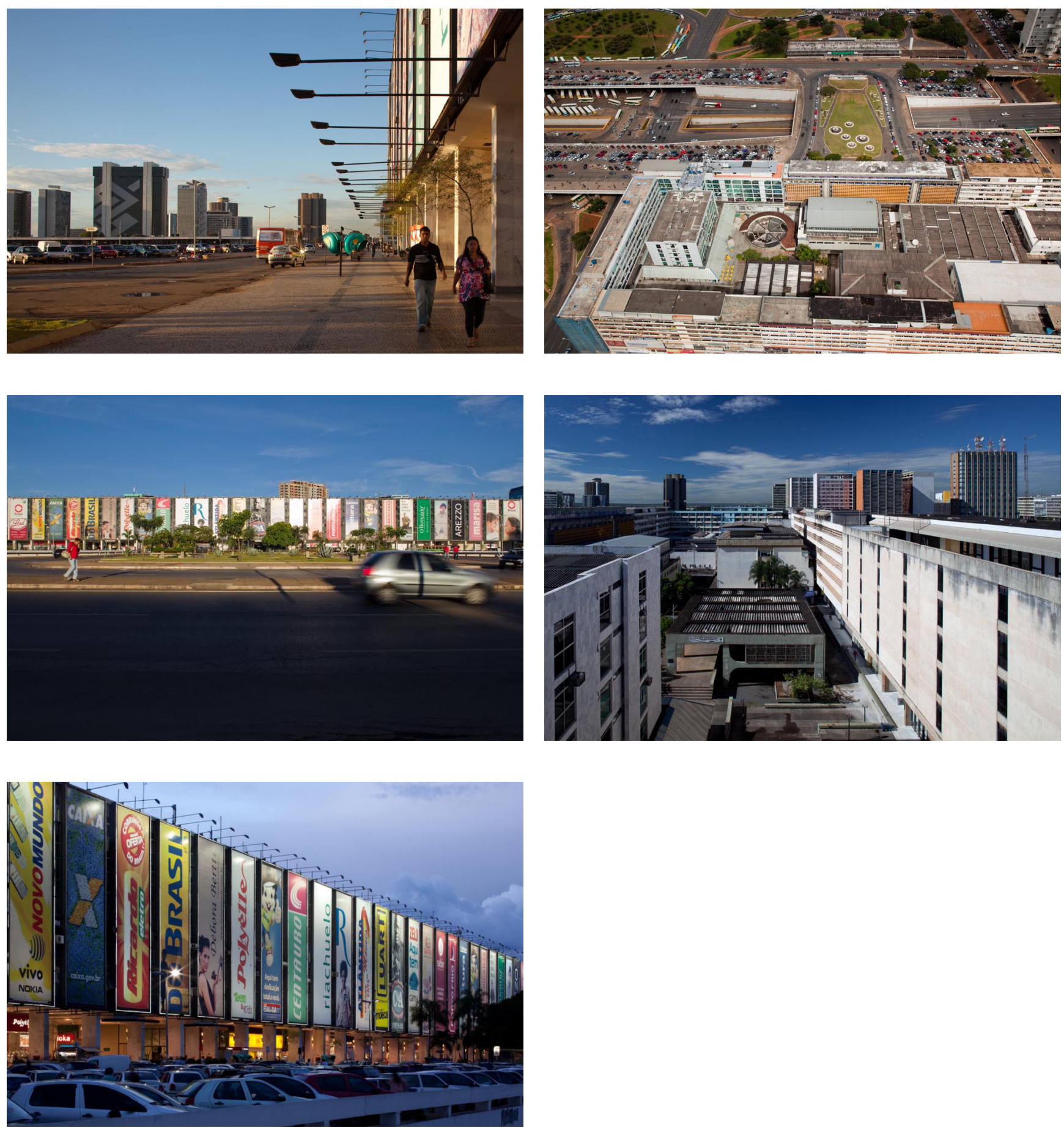

figs. 32 a 34 - Fachada frontal do Conjunto Nacional, com a galeria coberta em primeiro plano. Fonte: Nelson Kon,

figs. 35 e 36 - Vistas aéreas dos espaços interiores do 2010. 
cional apresente uma condição um pouco mais permeável e esteja em melhor estado de conservação tornando o ambiente ao nível do pedestre menos agressivo. A galeria, contínua e animada com vitrines de espaços comerciais menos decadentes que os do Conic, garante um passeio parcialmente coberto com extensão razoável no nível superior. Os conjuntos de escadas rolantes no interior do edifício são poucos e não chegam a possibilitar um fluxo intenso em direção à cota inferior. $\mathrm{Na}$ face Oeste ocorre a mesma situação encontrada no bloco Sul, criando uma fachada muito secundária, de fundos, embora com um aspecto menos degradado (fig. 31). A administração única dos níveis comerciais, mais próximos ao nível dos pedestres, fez com que o Conjunto Nacional adquirisse uma formalização próxima ao dos shopping centers das grandes cidades.

\section{Lado Leste - Casa de Chá e Teatro Nacional}

Em frente ao Conic, a 180 metros de distância, há o pavilhão da Casa de Chá, prevista originalmente no Plano Piloto, embora nunca utilizada para essa finalidade. Atualmente o edifício está parcialmente desocupado e não permite conexão entre a cota superior da plataforma e a cota do Setor Cultural, em que foram recentemente inauguradas a Biblioteca Nacional e o Museu da República. No nível inferior há uma estação de serviços de abastecimento para automóveis. $O$ pavilhão baixo - com aproximadamente 5 metros de altura total, 100 metros de extensão por 30 metros de largura -, respeita a volumetria prevista originalmente. Embora o edifício como projetado não possibilitasse um grande fluxo de circulação vertical a fim de conectar a parte alta com o Setor Cultural, se estivesse em funcionamento com o caráter público imaginado, promoveria maior permeabilidade peatonal no sentido transverso.

Na porção Norte está localizado o Teatro Nacional, que se conecta à cota superior da plataforma através de uma passarela de pedestres que dá acesso ao grande foyer da sala principal, ao mesmo tempo que protege o acesso no nível inferior, com passagem de veículos. Considerando as circulações verticais no interior do edifício e a generosidade dos espaços internos é o edifício que melhor realiza a conexão entre as cotas da plataforma e do Setor Cultural, sendo possível perceber ali a riqueza dessa articulação. 
Apesar do potencial que essa condensação de programas e sua disposição espacial cria, esta articulação não se realiza plenamente. Como nota a pesquisadora da UNB, Gabriela Tenório, em trabalho apresentado no X Seminário de História da Cidade e Urbanismo, essa situação ocorre "não porque alguns espaços a ela destinados estejam desocupados [...] mas por falhas de desenho." (Tenório, 2008). As diferenças entre o efetivamente construído e o plano original, que serão abordadas no próximo capitulo, truncaram a continuidade entre os setores centrais de Brasília. Além de um desenvolvimento dos projetos das edificações de todo o entorno pouco atento a esses aspectos fundamentais, a própria topografia criada pelos terraplenos para realizar a transposição dos eixos macroestruturais cria descontinuidades nas áreas externas a esses edifícios.

Por isso, embora a localização da plataforma e as dimensões de sua estrutura permitam de fato a conexão entre diferentes setores, usos e edifícios, especialmente em seu nível superior, após uma análise do edifício e seu entorno imediato é possível perceber o quão mais dinâmico poderia ser o conjunto e as possibilidades enormes de ocupação e conectividade sub-aproveitadas que oferece. A principal descontinuidade é no sentido Leste-Oeste, mas o ambiente pouco adequado ao pedestre, com suas calçadas estreitas e desqualificadas para superar as grandes distâncias no sentido Norte-Sul, na cota superior, e a ausência total de conexões entre esses edifícios nas cotas inferiores da plataforma, inibem enormemente o fluxo de pessoas entre as diferentes estruturas que compõem a escala gregária de Brasília. 
desenhos: plantas e cortes da plataforma rodoviária

Os encartes que se seguem são desenhos, plantas dos principais níveis da plataforma, em escala 1:1.500, e cortes longitudinal e transversos pelo conjunto, incluíndo os edifícios do entorno imediato, em escala 1:1.500 e 1:750. Estes desenhos foram produzidos no âmbito desta pesquisa apartir de desenhos de referência de um projeto de intervenção na plataforma, levantamentos de arquivo e de levantamentos fotográficos e visita ao local. São desenhos bastante completos e fiéis ao estado atual do edifício. Foi notável a dificuldade encontrada em localizar e compatibilizar fontes esparsas dos diferentes edifícios, o que sugere que não haja desenhos que contemplem de forma integrada a área. 
T1101101 प

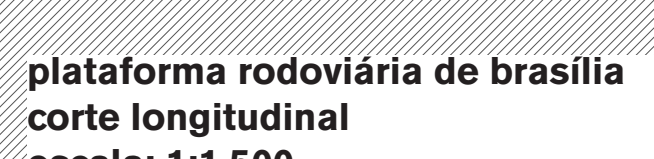

A plataforma rodoviária de Brasilia: infraestrutura, arquitetura e urbanidade 


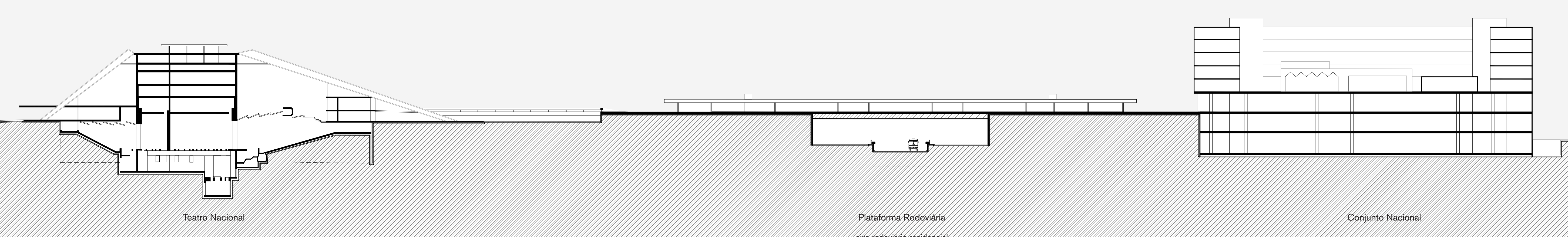

$5-x=5$ 

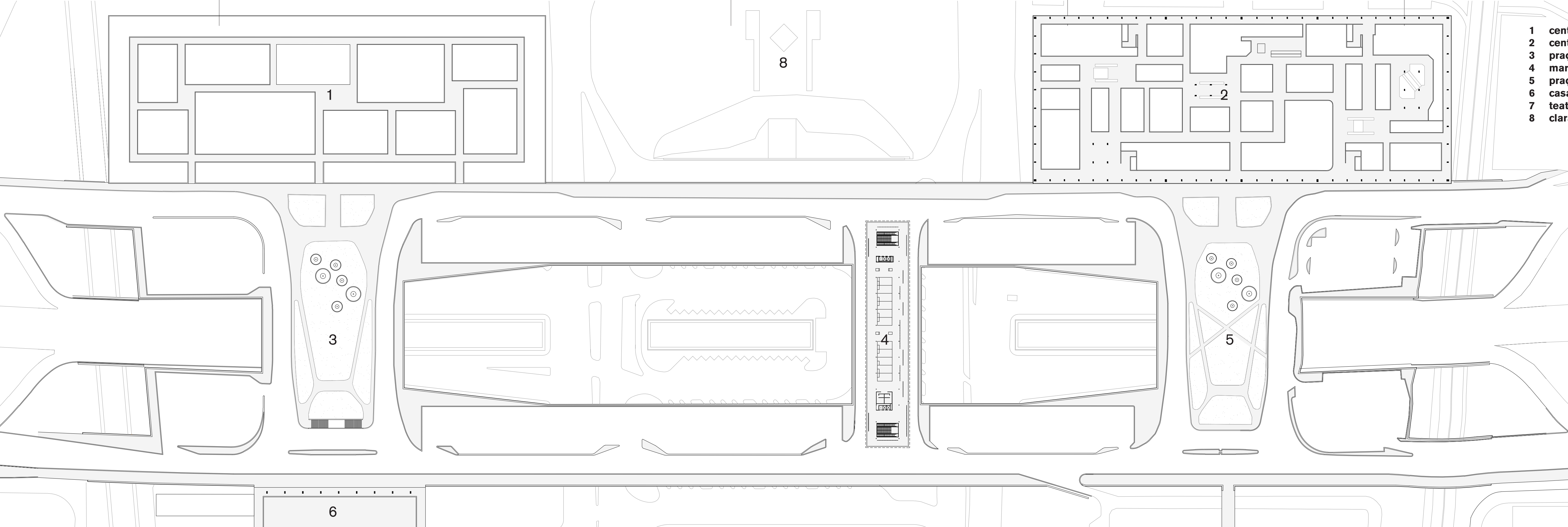

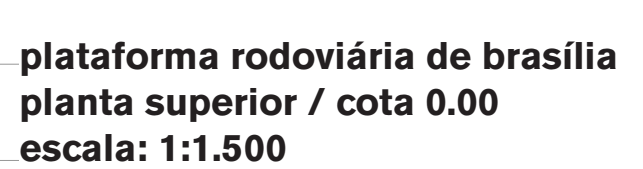

A platatorma rodoviária de Brasilia: infraestrutura, arquitetura e urbanidade 

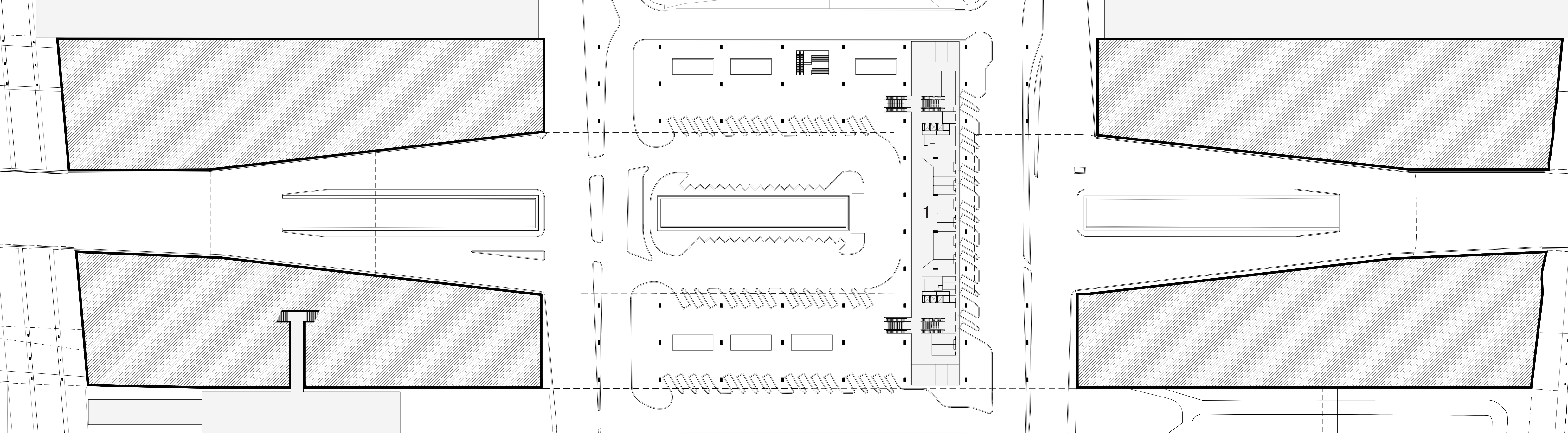

.

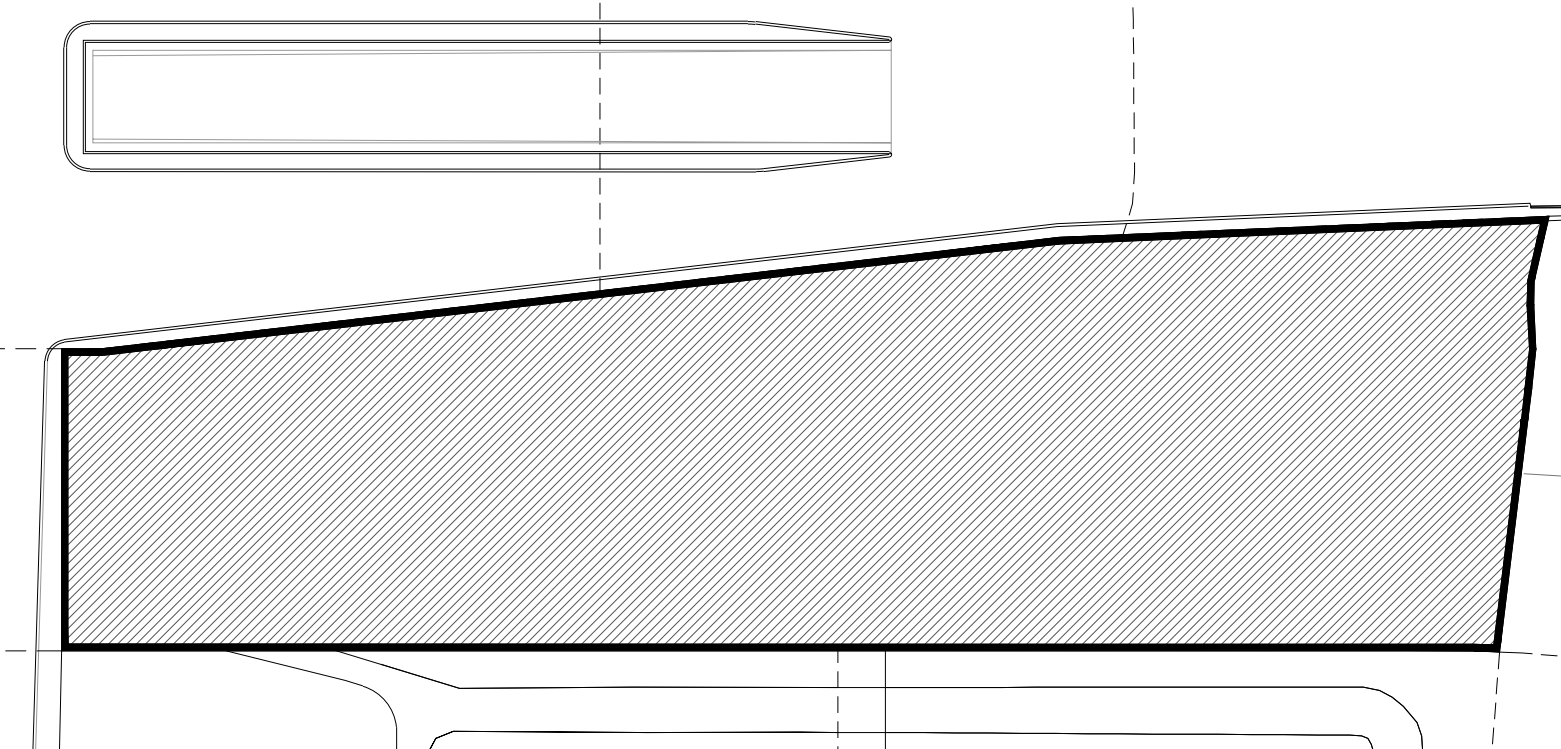

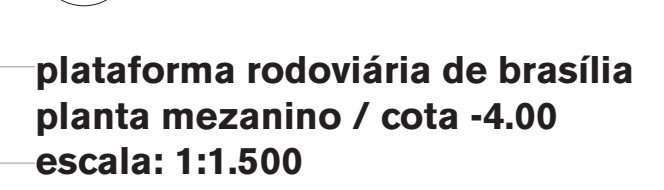

A platatororma rodovíría de Brasilia: infraestrutura, arcuitetura e urbanidade 

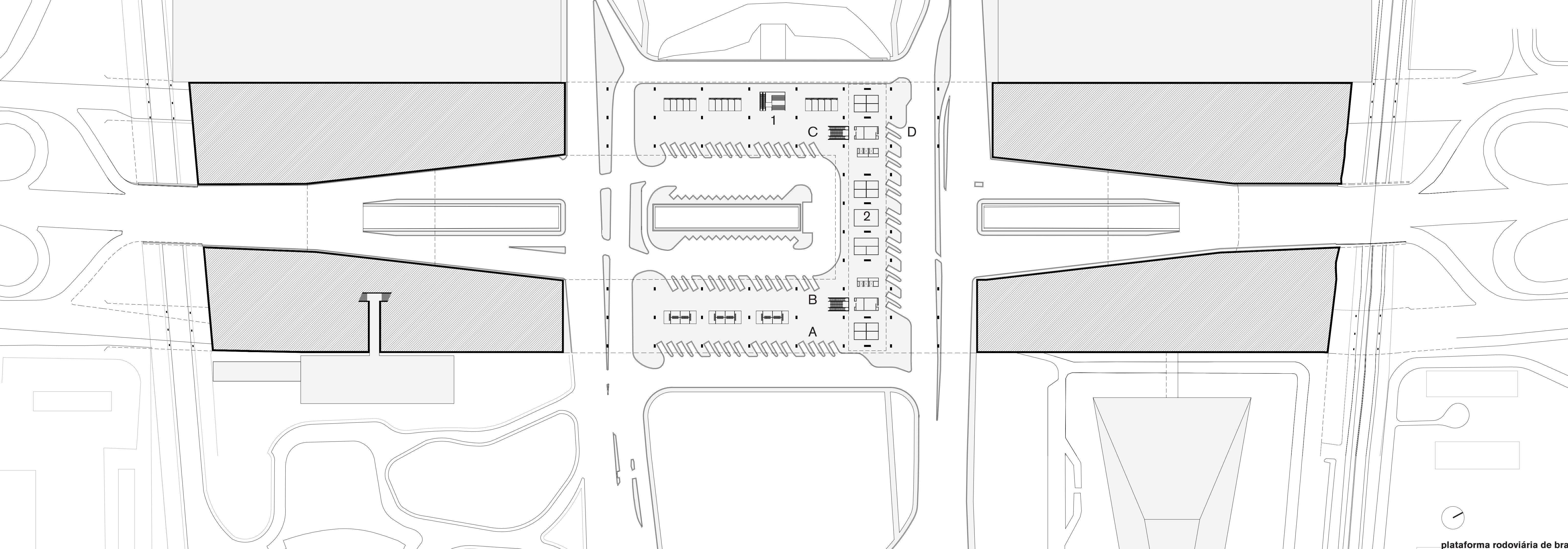

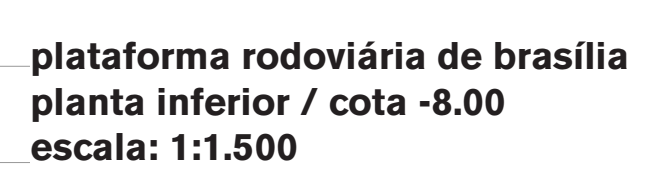

A platatororma rodoviária de Brasilia: infrraestrutura, arquitetura e urbanidade 
capítulo 3 - A plataforma rodoviária no tempo 

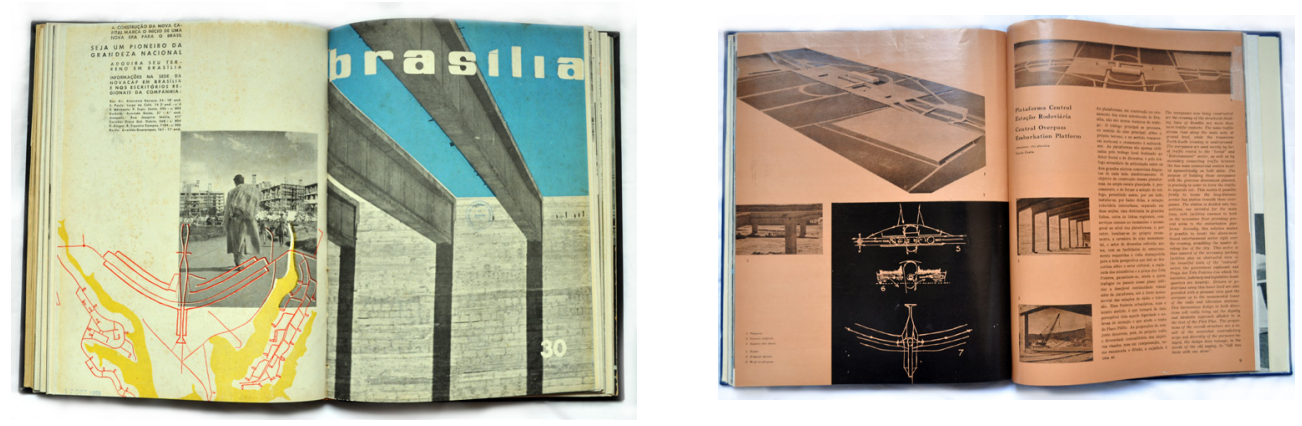

figs. 37 a 42 - Reproduções de todas as publicações da plataforma rodoviária em periódicos especializados. Da esquerda para a direita e de cima para baixo:

Revista Brasília, 1959

Revista Módulo, 1959

Revista Brasília, 1960
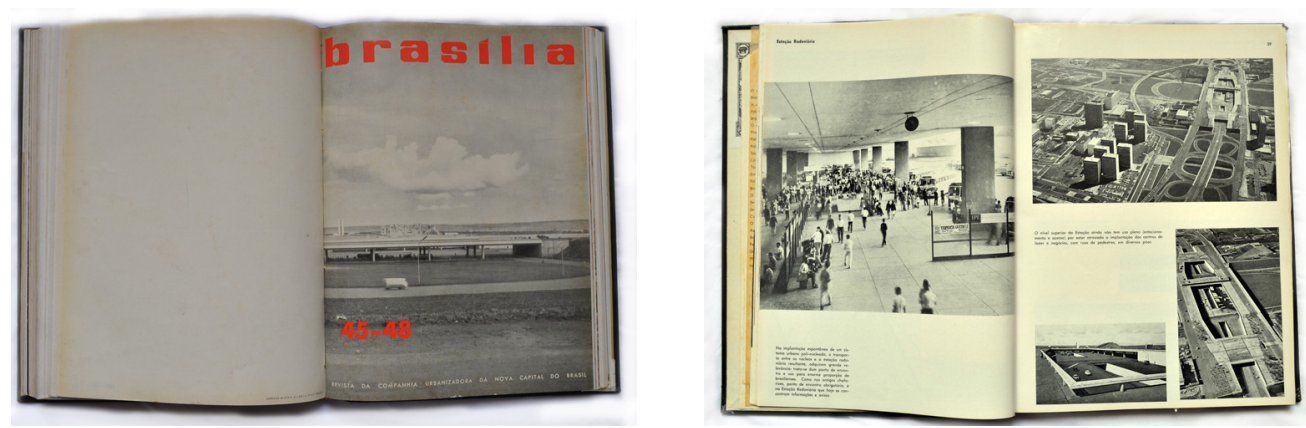

Revista Acrópole, 1960

Revista Brasília, 1961

Revista Acrópole, 1970
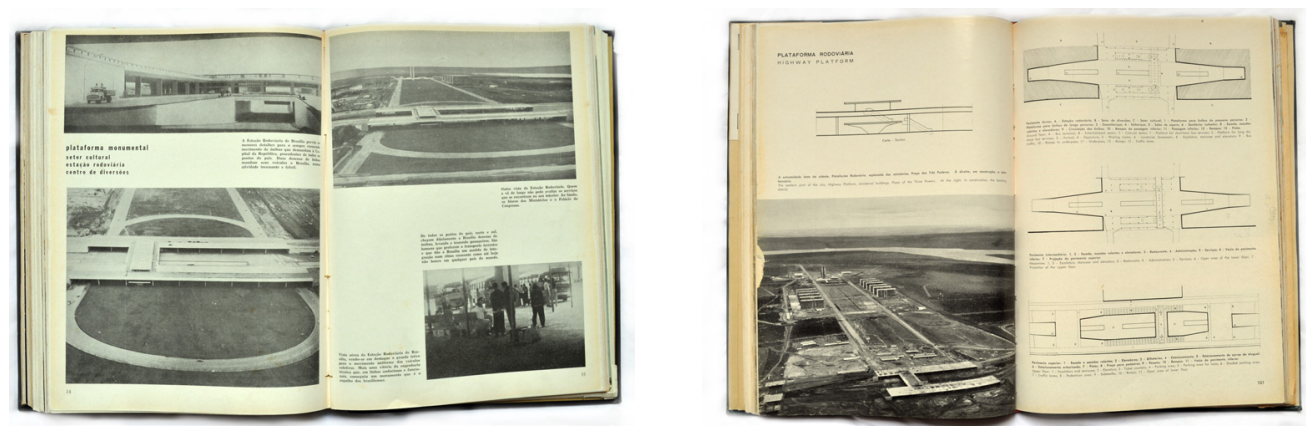


\section{A plataforma rodoviária no tempo}

Neste capítulo serão descritos o projeto da plataforma de Brasília e sua relação íntima com o Plano Piloto apresentado por Lucio Costa ao júri do concurso, em 1957 - desde as suas premissas até os aspectos técnicos de sua construção -, e algumas modificações relevantes ocorridas ao longo dos cinquenta anos de sua existência.

\section{publicações}

Como introdução - e como analogia às transformações da própria estrutura - vou abordar brevemente as transformações da representação da plataforma rodoviária nas escassas publicações especializadas de que foi objeto. Apesar de ser um edifício importante na configuração de Brasília, a plataforma rodoviária recebeu pouca atenção como projeto autônomo, ficando geralmente em segundo plano em relação edifícios mais icônicos de Brasília. Desde o início das obras até o cinquentenário da inauguração da capital, pude levantar apenas dez publicações em que o projeto ou edifício figura destacado como peça autônoma entre os principais periódicos especializados como Habitat, Módulo, Brasília, Acrópole, Projeto e $A u$. Também aparece com destaque em apenas três livros publicados nesse período, mesmo dentre os muitos títulos publicados por ocasião do cinquentenário.

A primeira publicação do projeto ocorreu em 1959, na revista Brasília, editada pela Novacap, empresa responsável pela coordenação da implantação da cidade. Apenas no número 30 dessa publicação aparecem as primeiras fotos da obra, com suas vigas em concreto na capa. Sob o 

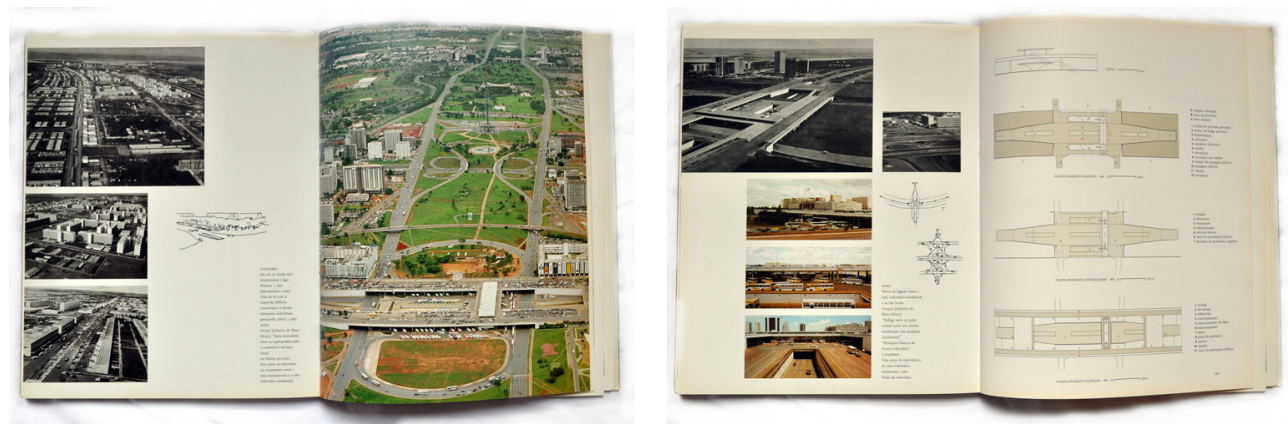

figs. 33 a 45 - Reproduções de todas as publicações da plataforma rodoviária como projeto autônomo, destacado, em livros:

Lucio Costa, Guilherme Wisnik, CosacNaify, 2001

O concurso de Brasília, Milton Braga, CosacNaify, 2010

Arquivo Brasilia, Lina Kim e Michael Wesely, CosacNaify, 2011
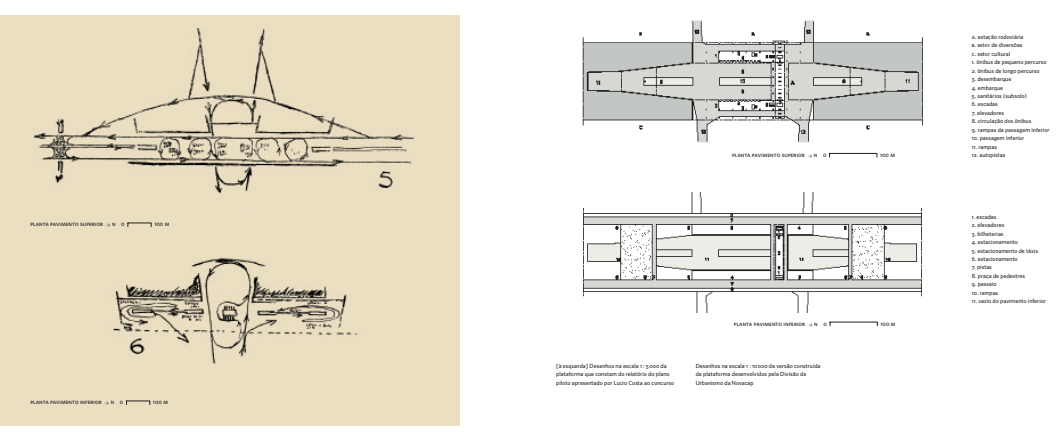

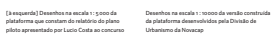

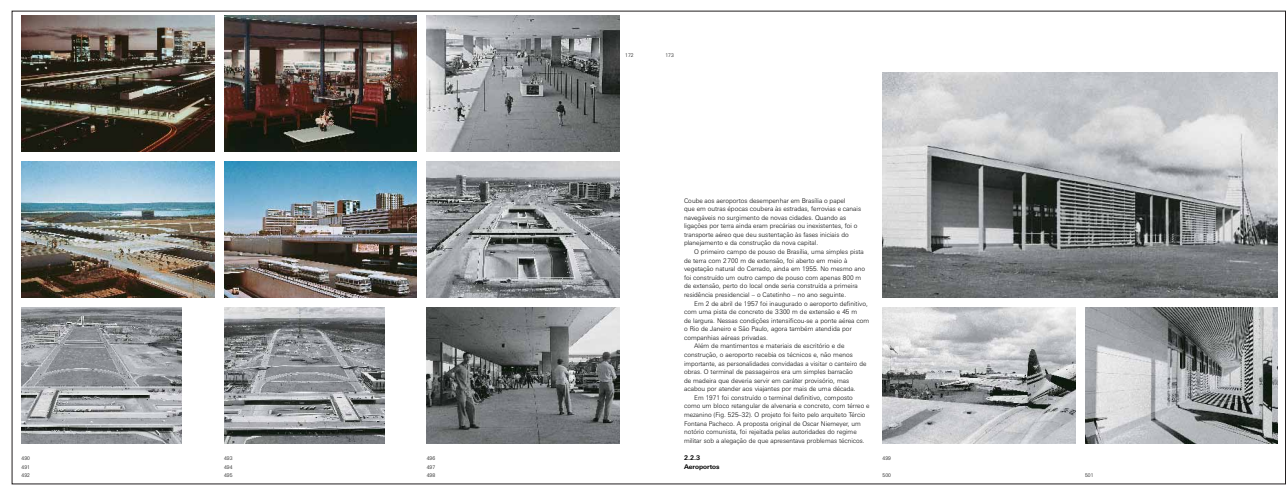


sugestivo título "Arquitetura e Urbanismo", o edifício é apresentado como "Plataforma Central", sem desenhos ou maiores descrições. Além das imagens do canteiro há reproduções de uma maquete, que representa a plataforma e um edifício anexo, que não veio a ser construído. Os primeiros desenhos esquemáticos aparecem no número 14, em 1959, da revista Módulo, editada por Oscar Niemeyer. Destacada como um dos edifícios emblemáticos de Brasília, ela aparece sob o título "Plataforma Central/ Estação Rodoviária". O texto, não assinado, aponta a aparente incompatibilidade entre a superposição de funções de esplanada de convívio e estação rodoviária, que, no entanto, se resolvem graças às "proporções do conjunto" que "decorrem do vulto e diversidade contraditória dos objetivos visados, mas [...] a cajadada é uma só." (Módulo, 1959). A apresentação seguinte do projeto ocorre na revista Acrópole, logo em seguida, em abril de 1960, em número especial dedicado a Brasília. Ainda em obras, aparece sob o título "Plataforma Rodoviária". Em dezembro de 1960, a revista Brasília volta a publicar o projeto, por ocasião da inauguração, e reproduz o discurso do presidente Juscelino Kubitschek. A mesma revista a publicaria ainda outra vez, em 1961, ressaltando novamente o caráter multifuncional do edifício.

O edifício voltaria a ser publicado apenas em 1970, em outro número especial dedicado a Brasília, em comemoração aos dez anos da inauguração, de forma muito sumária e sem comentários analíticos. Somente em 2001 voltou a ser objeto de interesse, mais de trinta anos depois, quando fez parte da monografia sobre Lucio Costa, de Guilherme Wisnik, quando é apresentada como "rodoviária" (Wisnik, 2001). Em 2010, Milton Braga, em seu livro sobre o concurso de Brasília (Braga, 2010), dedica um trecho à análise do edifício, mostrando as diferenças entre o projeto original e o efetivamente construído, e a consequente superposição da função rodoviária sobre as funções de articulação da escala gregária. Nesse mesmo ano, Arquivo Brasília, pesquisa de imagens de arquivo realizada por Michael Wesely e Lina Kim, resgatou em uma publicação monumental uma série de imagens da plataforma, em que se registram diferentes fases da obra e do edifício concluído. Somado a esse interesse renovado, em parte motivado pelo cinquentenário da capital, foi publicado um arti- 


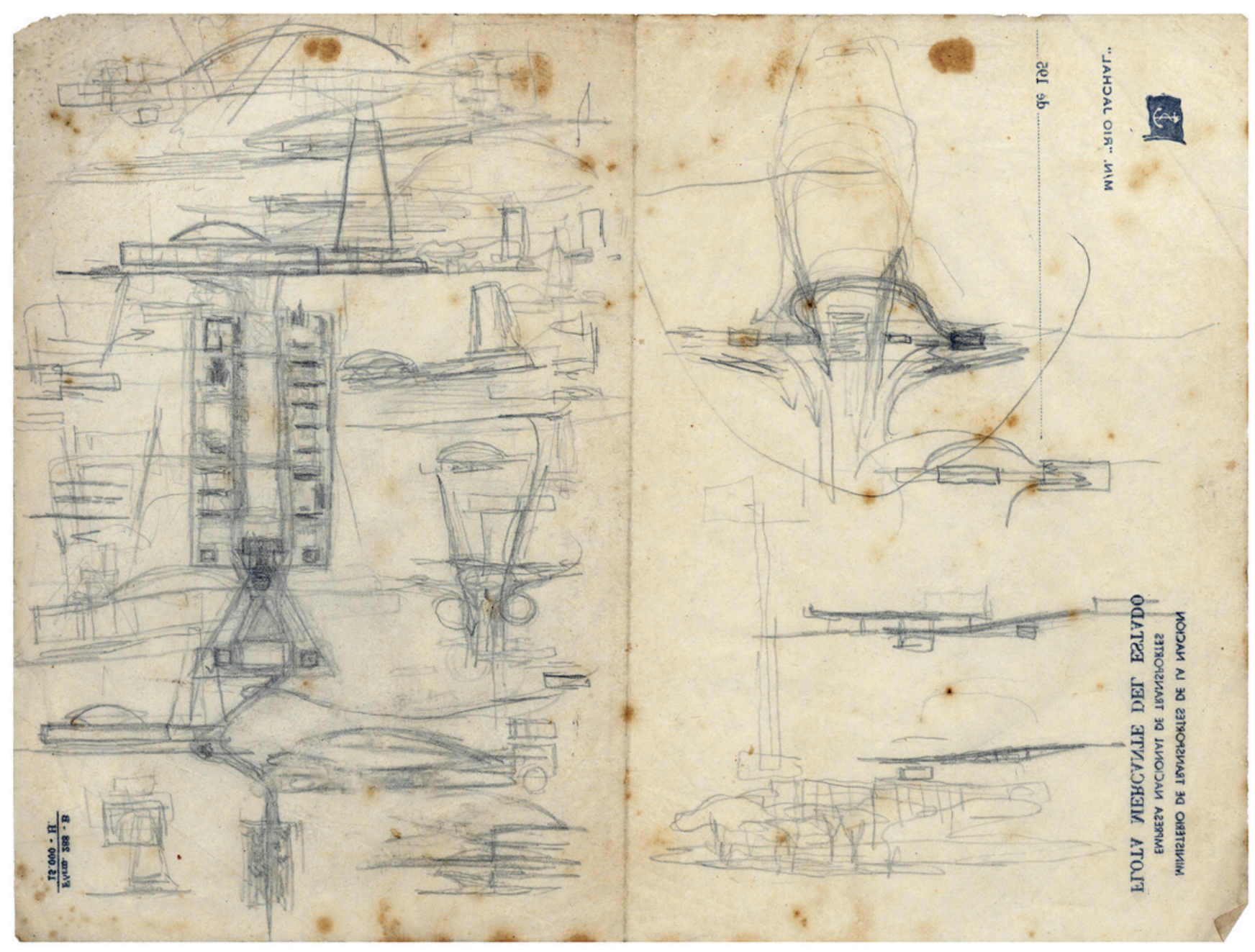

fig. 46 - Croquis de Lucio Costa feitos duarante a viagem de volta dos Estados Unidos, em navio, em 1957, em que iniciou os estudos para o Plano Piloto. A direita da folha os primeiros esboços da solução de transposição dos eixos e da plataforma rodoviária. Fonte: Acervo Casa de Lucio Costa. 
go do pesquisador Eduardo Rossetti no portal de internet Vitruvius que apresenta uma leitura atual do edifício e seus usos.

De todo esse percurso brevemente descrito aqui é interessante notar como foram lidas e divulgadas ao longo do tempo as funções superpostas da plataforma rodoviária. Assim como no Relatório do Plano Piloto (Costa, 1995), a primeira descrição da plataforma destaca a sua função como articuladora dos espaços centrais de Brasília e coloca em segundo plano a função de estação rodoviária:

"5. O cruzamento desse eixo monumental, de cota inferior, com o eixo rodoviário-residencial impôs a criação de uma grande plataforma liberta do tráfego que não se destine ao estacionamento ali, remanso onde se concentrou logicamente o centro de diversões da cidade, com os cinemas, os teatros, os restaurantes etc." (Costa, 1995, Relatório do Plano Piloto, p. 3).

Gradativamente no entanto, sua função como nó infraestrutural ganha o primeiro plano. Essa mudança na percepção do projeto é significativa e indica que, por um lado, a sua performance como articulação dos espaços de convivência e de vitalidade previstos não se realizou plenamente. Em função da demora em consolidar os edifícios de seu entorno imediato e por deficiências nos projetos no que diz respeito à integração ao conjunto como imaginado originalmente, a função mais cotidiana e imediata, de peça chave do sistema de transporte público da cidade, se tornou preponderante. Por outro lado, o crescimento da região de Brasília, com a consolidação dos assentamentos em seu entorno, transformou rapidamente a estação rodoviária em centro de um sistema metropolitano. Ou seja, se a função de socialidade não se realizou como imaginada, a função infraestrutural superou a expectativa inicial. Essa transformação foi em parte possível, como já exposto, pelas dimensões e pela generosidade espacial do recinto pois, se as transposições, fluxos e articulações com um entorno frágil não se realizaram de modo adequado, os seus espaços foram abrigo suficiente para um incremento substancial de seu uso como estação rodoviária e também para apropriações informais e imprevistas desses espaços, que permitiram o aparecimento de um tipo 


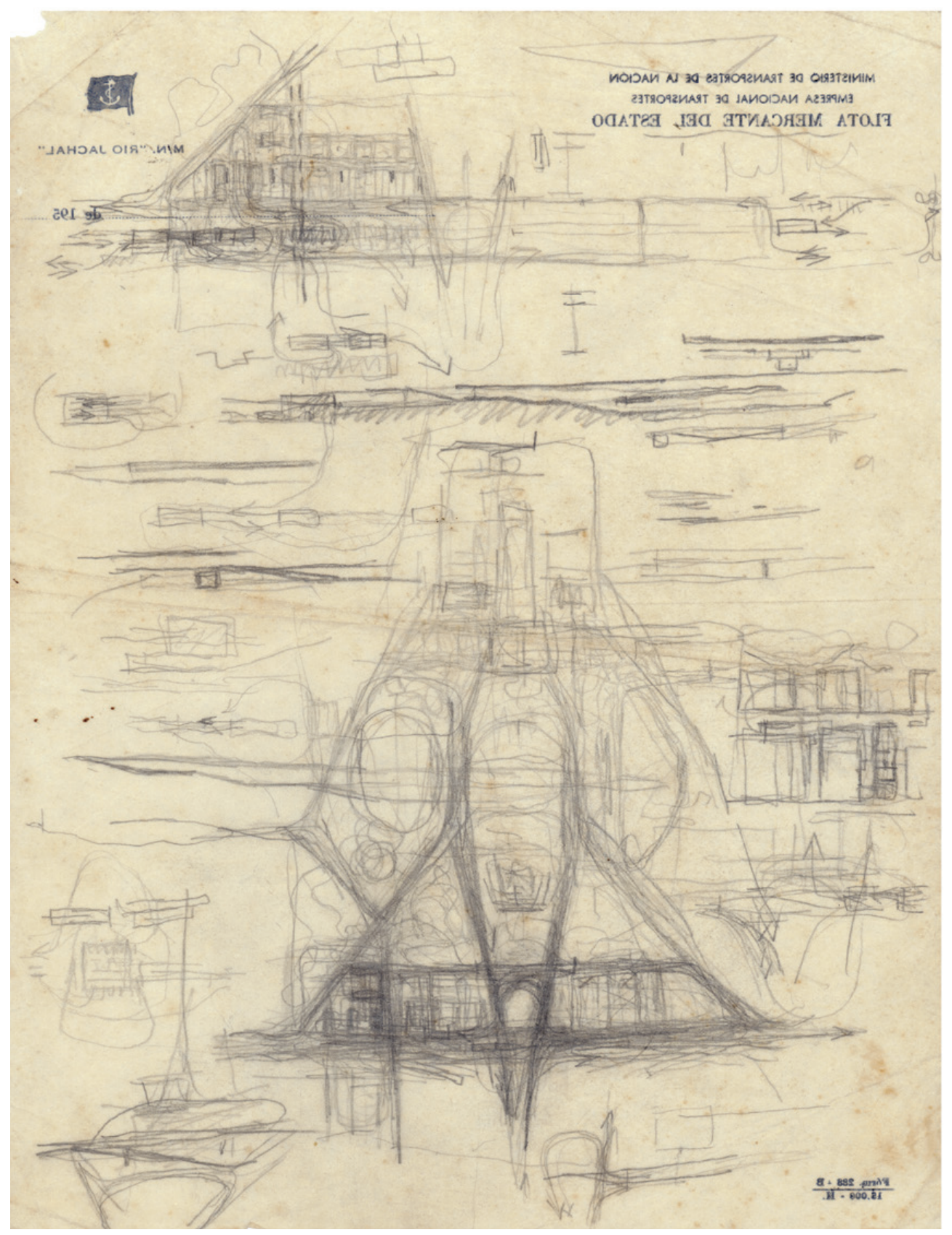

fig. 47 - Croquis de Lucio Costa feitos duarante a viagem de volta dos Estados Unidos, em navio, em 1957, em que iniciou os estudos para o Plano Piloto. Esboços da solução de transposição dos eixos e da plataforma rodoviária. Fonte: Acervo Casa de Lucio Costa. 
de socialidade popular muito diversa do imaginado no projeto original.

Lucio Costa comenta com otimismo a apropriação espacial imprevista da plataforma por uma população trabalhadora, tornando-a um lugar de diversidade e encontro, um espaço do que estou chamando de "urbanidade".

"Aquela plataforma é fundamental lá no Plano, em três níveis, naquele cruzamento [...]. É que eu tinha concebido essa plataforma rodoviária no centro do Plano Piloto como um centro muito cosmopolita [...] como uma coisa muito civilizada e cosmopolita. O café, com aquela vista linda da esplanada [...] invés daquele centro cosmopolita requintado que eu tinha elaborado, (o centro) tinha sido ocupado pela população periférica, a população daqueles candangos que trabalham em Brasilia. Era o ponto de convergência, onde eles desembarcavam e havia então esse traço de união, era um traço de união entre a população burguesa, burocrata com a população obreira e que vivia na periferia. [...] Foi o Brasil de verdade, o lastro popular que tomou conta da área. Isso deu uma força enorme à Capital, me fez feliz de ter contribuído involuntariamente para essa realização." (Lucio Costa, data, s/p, apud Eduardo Rossetti, data)

\section{centro de diversões}

O tipo de espacialidade imaginada por Lucio Costa para os conjuntos construídos no lado Oeste da plataforma, "centro de diversões da cidade", seria uma "mistura em termos adequados de Picadilly Circus, Times Square e Champs Elysées". E as várias casas de espetáculo que comporiam os conjuntos a Norte e Sul, atuais Conjunto Nacional e Conic, seriam "ligadas entre si por travessas do gênero tradicional da rua do Ouvidor, das vielas venezianas ou de galerias cobertas (arcades) e articuladas a pequenos páteos com bares e cafés, e 'loggias' na parte dos fundos com vista para o parque, tudo no propósito de propiciar ambiente adequado ao convivio e à expansão". (Costa, data, s/p. Relatório do Plano Piloto, p. 7.) 


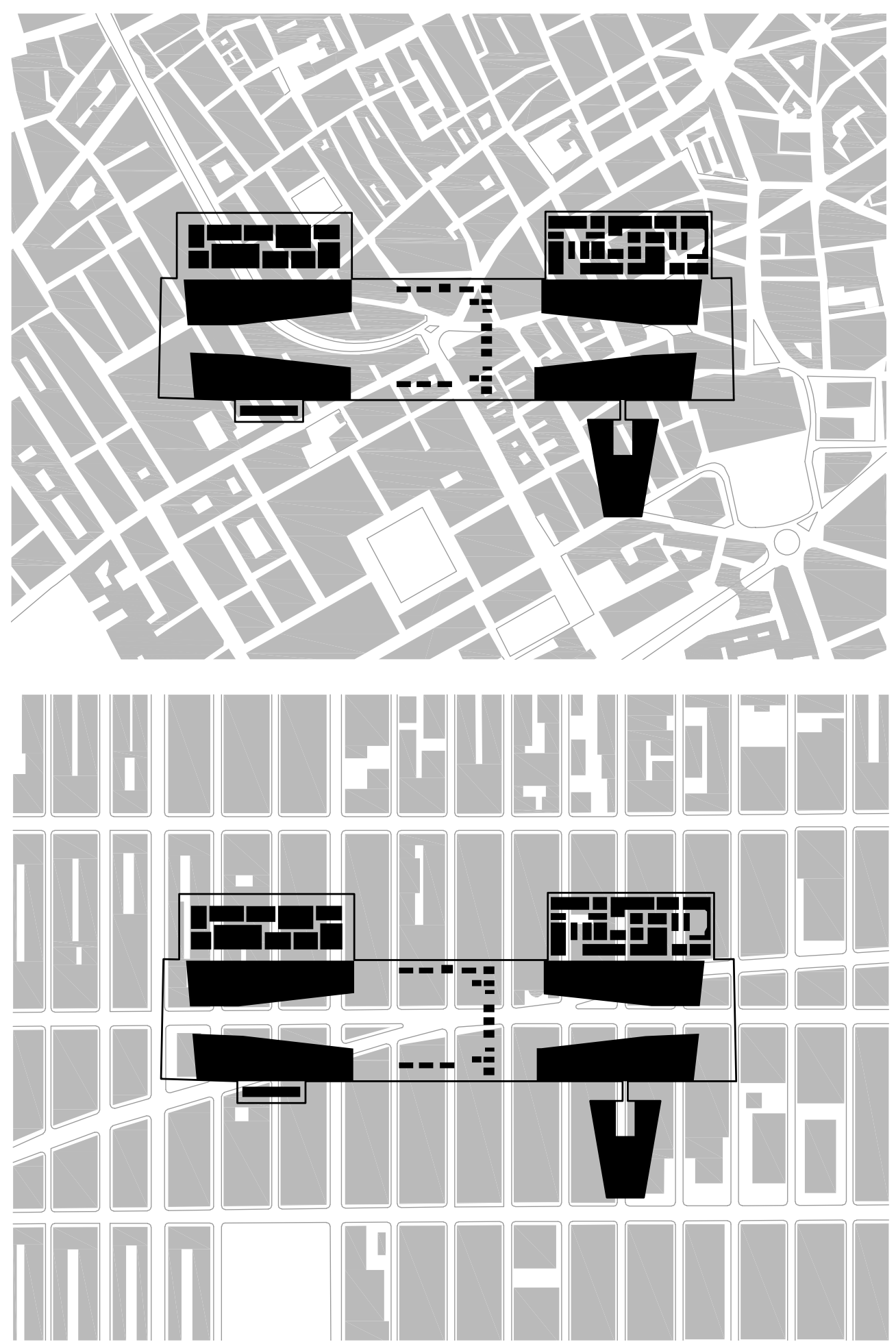

diagrama 8

Picadilly Circus - Londres

\section{diagrama 9}

Times Square - Nova lorque

diagramas comparativos de densidade Um ensaio de sobreposição de diagramas esquemáticos de cheios e vazios dos espaços construídos hoje no entorno da plataforma com as referências de espaços de urbanidade usadas por Lucio Costa no relatório do Plano Piloto. 


\section{diagrama 10}

Champs Elysées - Paris

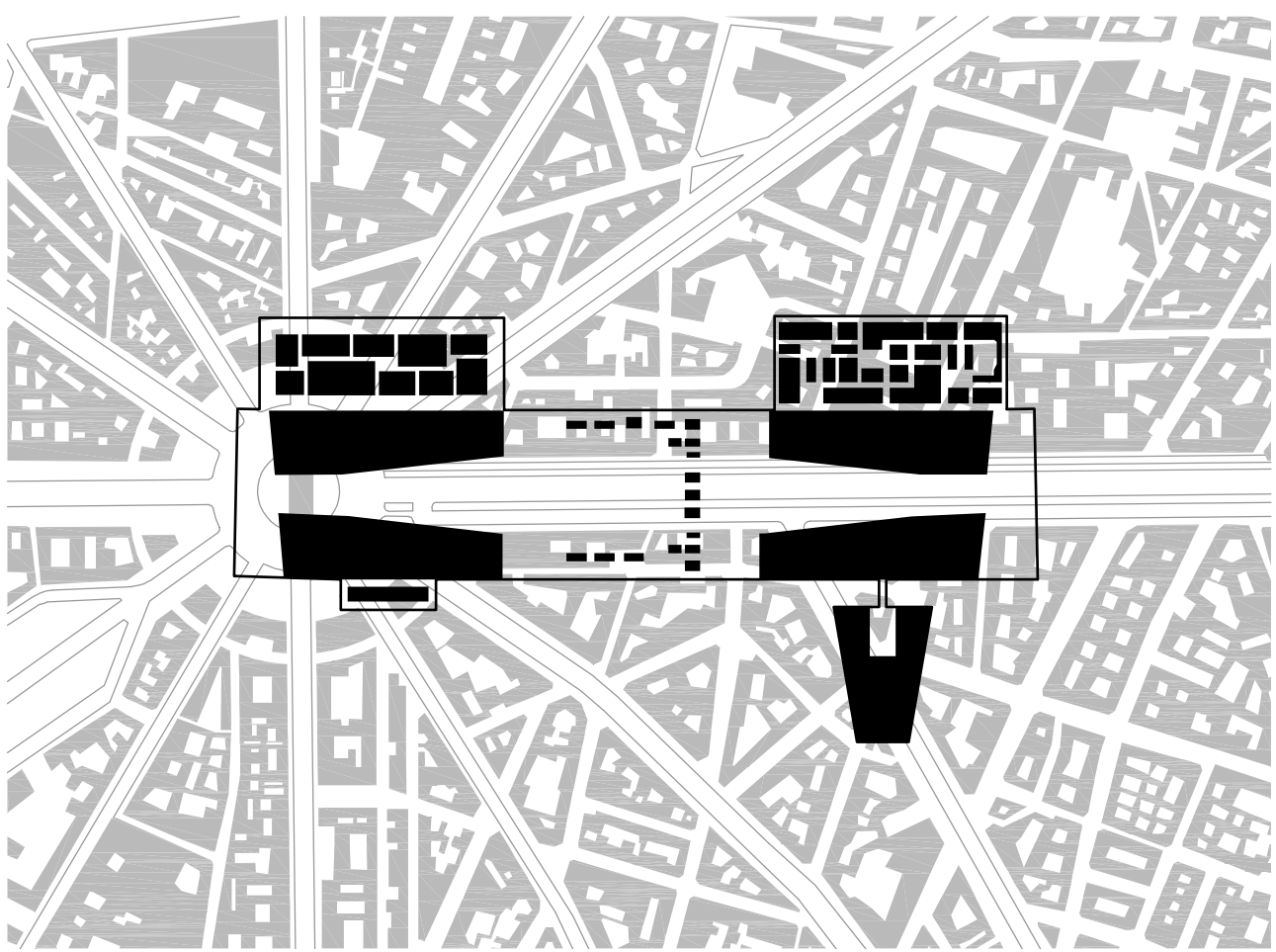

\section{diagrama 11}

Cinelandia - Rio de Janeiro

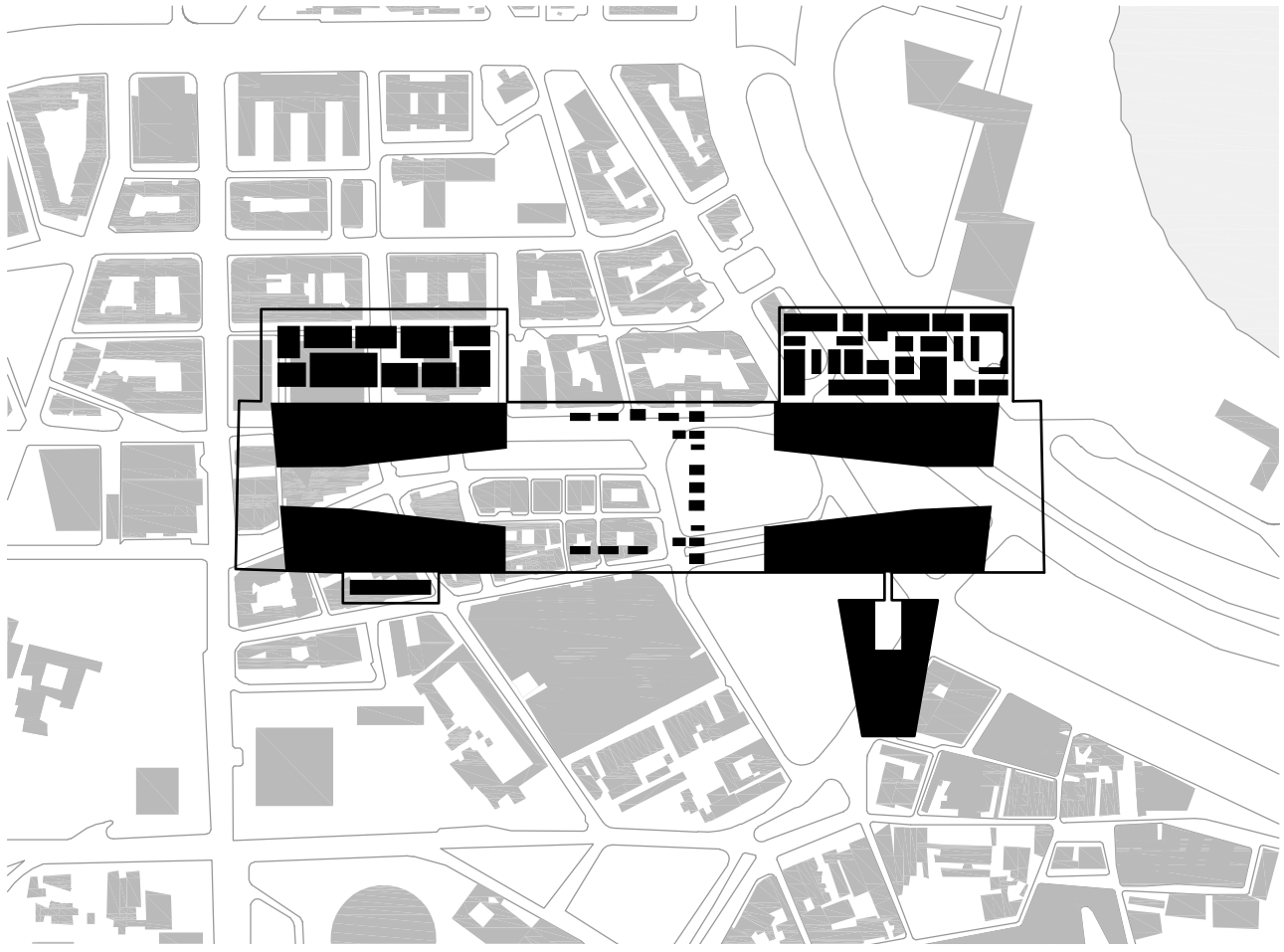

Com exceção do grande eixo dos Champs Elysées, os vazios do recinto da plataforma superam em muito os das cidades tradicionais. No entanto o "grain" dos centros de diversões são bastante próximos aos dos centros aos que se comparam. Não fossem os defeitos de desenho desses edifícios, sua escala permitiria a constituição de ambientes análogos. 


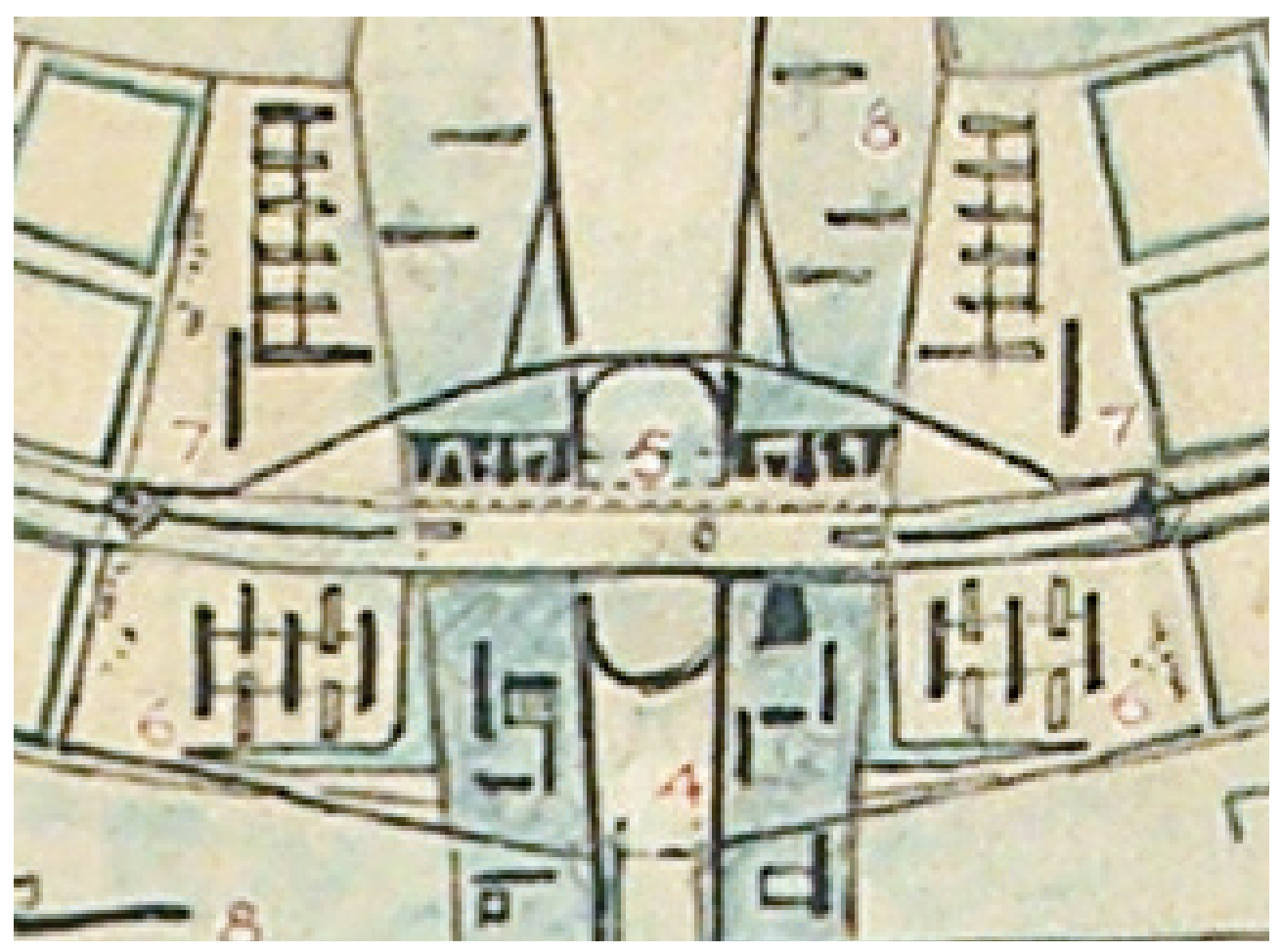

fig. 48 - Detalhe da planta geral do Plano Piloto de Lucio Costa, em 1957, com o setor central bastante definido e muito próximo ao construído. Como diferenças fundamentais estão o partido espacial dos centros de diversões, já discutido aqui, que prejudica a mobilidade no sentido Leste-Oeste, e a não construção do volume central, paralelo à plataforma, que através de seu térreo livre permitiria maior qualidade e fluidez na mobilidade no sentido Norte-Sul. O sistema viário propriamente dito foi seguido sem maiores alterações. Fonte: Acervo Casa de Lucio Costa. 
Essa espacialidade não se realizou nos edifícios do centros de diversões, como visto anteriormente. O Conjunto Nacional, construído em três fases e inaugurado apenas em 1971, adquiriu um caráter de shopping center genérico e não oferece o tipo de experiência descrita acima, embora desempenhe com relativa eficiência o papel de centro comercial. Foi projetado por Nauro Esteves, arquiteto de confiança de Lucio Costa, que no entanto exigiu que se respeitasse a determinação prevista na memória do concurso com relação à disposição de painéis luminosos na fachada Leste. Nauro Esteves, que havia projetado as quatro fachadas iguais, com caixilhos de escritórios, acatou a exigência e incorporou os painéis, com a modulação e proporção definidas por Athos Bulcão. Ainda que pouco permeável aos fluxos pedestres, o Conjunto Nacional é mais frequentado que o Conic, que apresenta uma sensação ainda menos agradável em relação à passagem ou à permanência. Em parte, a causa dessa condição está no fato de o Conic, inaugurado parcialmente em 1969, ter sido concebido como um volume único mas constituído por diversos blocos autônomos. Esses blocos foram sendo construídos de forma descoordenada e atenderam ao cronograma de investimento de diferentes proprietários. Essa construção em partes se revela ainda hoje na própria fachada do conjunto, bastante descontínua, e no estado de conservação irregular de seus diferentes trechos.

Comparando o croqui apresentado por Lucio Costa [fig. 49] ao júri do concurso com os Centros de Diversões, é possivel notar uma diferença significativa de "partido" arquitetônico entre a proposta original e o efetivamente construído. $\mathrm{O}$ edifício ilustrado pelo arquiteto corresponde ao centro de diversões Sul, hoje o Conic, e era composto por onze edifícios, ou blocos, autônomos e irregulares, conformando um único volume graças a seu alinhamento externo. Os vazios entre esses blocos conformavam as vielas de acesso a seus espaços interiores. Apesar do interior fragmentado e irregular, formavam-se alinhamentos diagonais transversos que cortavam todo o conjunto, permitindo assim longas visuais que garantiam a transparência do volume. No interior do conjunto estava esboçado um longo eixo longitudinal de articulação ao longo do qual se sucediam pequenos largos, sem no entanto bloquear as visuais ou a circulação de 


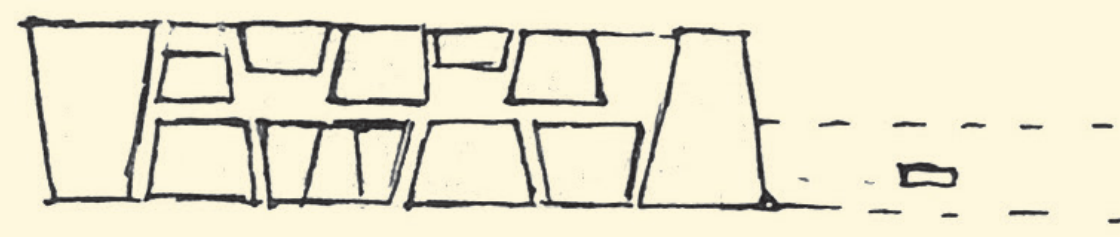

fig. 49 - Detalhe do croqui de número 11, integrante da memória do projeto apresentado ao júri do concurso, em 1957. Refere-se ao partido arquitetônico dos centros de diversões. A direita

- o volume central, não edificado, representado com o térreo livre a apenas uma das caixas de circulação tocando o solo. Fonte: Acervo Casa de Lucio Costa.

fig. 50 - Esquema do projeto efetivamente construído para o centro de diversões sul, conhecido como Conic.

fig. 51 - Esquema do projeto efetivamente construído para o centro de diversões norte, conhecido como Conjunto Nacional. 
pessoas. Esse eixo é apenas interrompido pelos dois volumes de arremate, nas extremidades do conjunto.

Já o partido do projeto ali implantado [fig. 50] é constituído por um anel periférico edificado contínuo e estreito, com sete pavimentos de altura e formado por oito edifícios justapostos. No interior desse retângulo há dez volumes regulares, dispostos segundo a organização determinada por um conjunto de vias de circulação ortogonal, porém descontínua. As passagens entre interior e exterior do bloco não estavam determinadas, embora fossem exigidas ao menos uma para cada edifício periférico.

No lado Norte da plataforma o partido arquitetônico é diverso, tanto do esboçado por Lucio Costa como do realizado no Conic, embora como resultado espacial se aproxime mais do último. $O$ partido explicita um aspecto não resolvido nos croquis originais ao eleger a cota superior da plataforma rodoviária como lugar de uma grande galeria periférica. Ao dar a volta ao conjunto, os três outros trechos da galeria não coincidem com o nível da rua, graças ao desnível dos terraplenos. Assim a galeria perimetral separa o edifício em dois volumes: um embasamento - que não articula satisfatoriamente os diferentes níveis do chão, especialmente o fundo, voltado ao setor hoteleiro, e a frente, com o nível da plataforma central - e um volume superior, em que se alojam os escritórios. Entre os dois foram distribuídos locais comerciais com uma estrutura de circulação ortogonal e descontínua, impedindo assim visuais transversas ao bloco e promovendo baixa permeabilidade para os pedestres que acessam o edifício ao nível superior da plataforma.

O croqui de Lucio Costa promovia uma fluidez e clareza ao conjunto que garantiria uma permeabilidade muito superior. Os eixos transversos que atravessam a totalidade do grande bloco garantem múltiplos acessos e principalmente transparência ao conjunto. A legibilidade da composição do bloco pela soma de partes autônomas também é garantida nesse esquema. Assim, se dilui o grande volume e permite-se a orientação e localização imediata de quem circula pelo espaço. No sentido longitudinal, um grande eixo visual e de circulação central evita o efeito labiríntico do arranjo construído, sem no entanto diminuir a complexidade do recinto, 


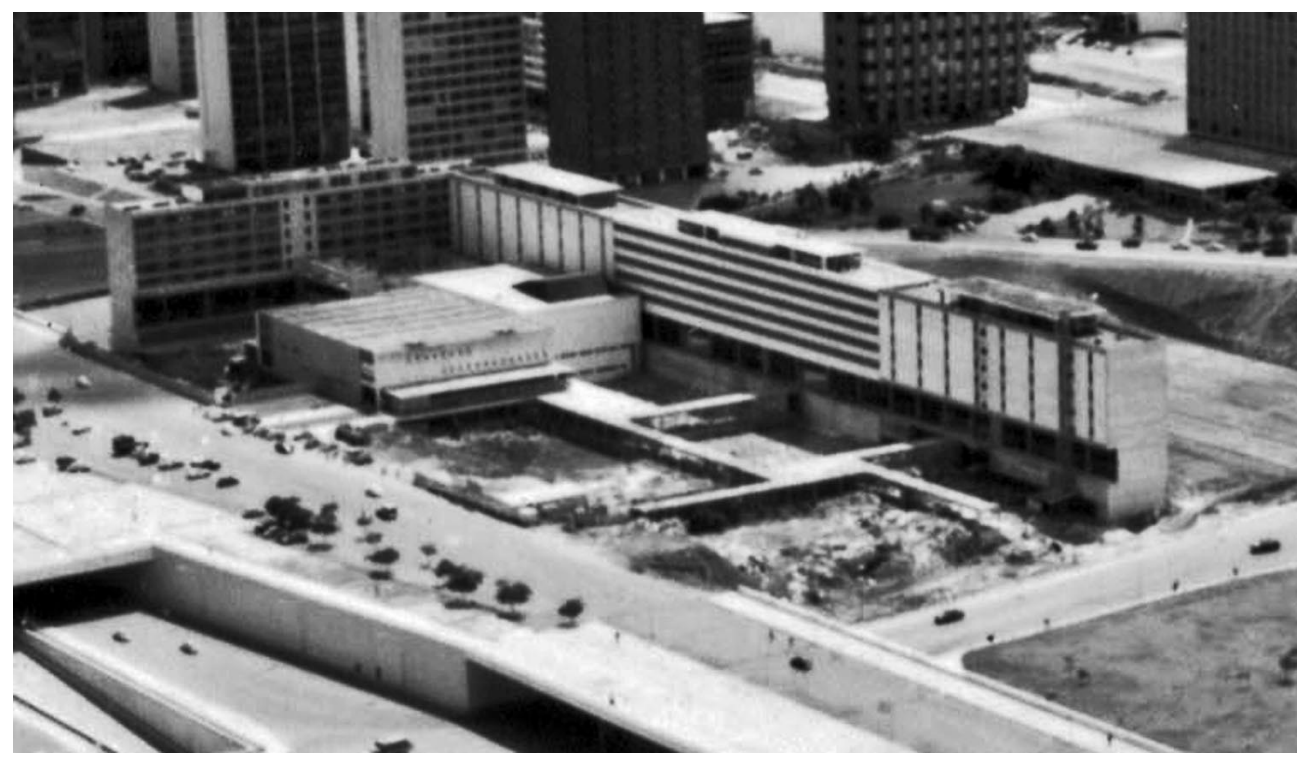

fig. 52 - Foto aérea de 1970 do Conic parcialmente construído. Vê-se aqui a laje de conexão construída previamente e a não coincidência de seu nível com o nível térreo dos edifícios periféricos e com o nível da plataforma rodoviária. Fonte: Arquivo Público do Distrito Federal.

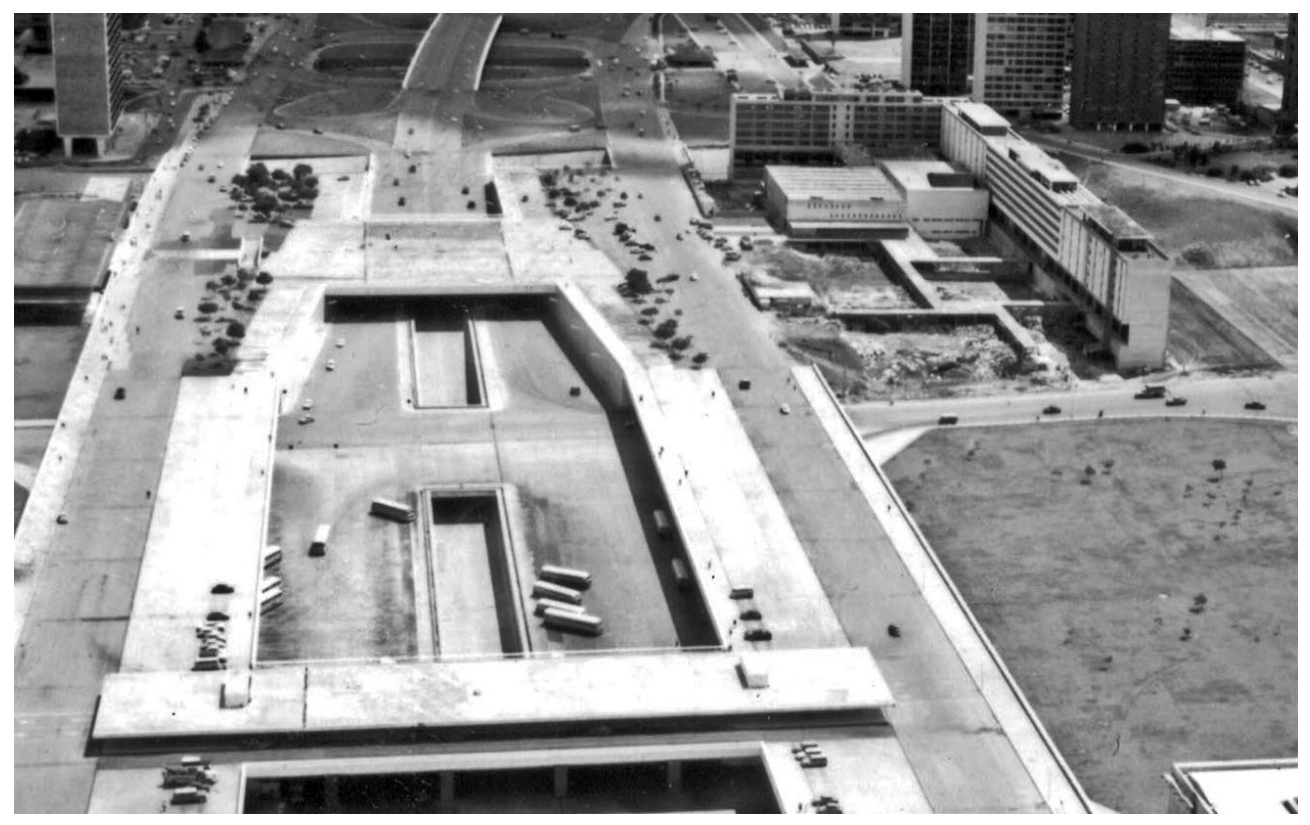

fig. 53 - Foto aérea de 1970 do Conic parcialmente construído. Fonte: Arquivo Público do Distrito Federal.

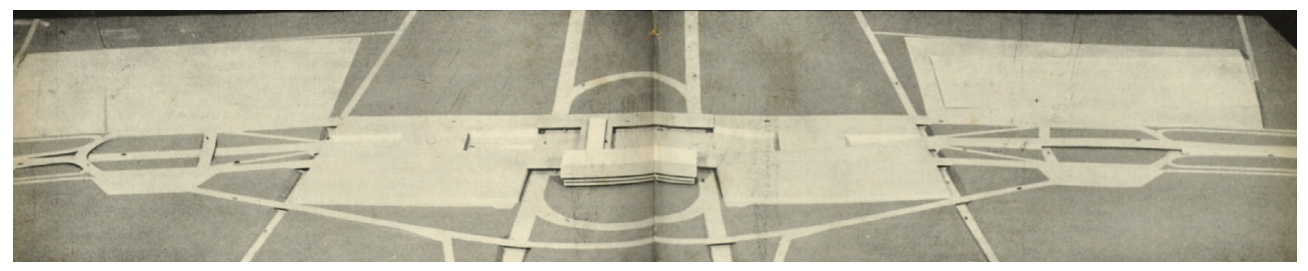

fig. 54 - Foto de maquete do setor central ainda com o edifício central de ligação entre os centros de diversão norte e sul. Fonte: Revista Brasília, 1959. 
composto por uma sucessão de vielas e largos com diferentes dimensões e ângulos. Embora não resolva um ponto crítico, como a deficiente articulação vertical entre as diferentes cotas do chão de suas faces, esse diagrama geraria espaços muito mais potentes e fluidos que os construídos, sendo possível pensar a partir dele formas de garantir essa articulação.

Além do partido labiríntico, a situação de descontinuidade do Conic com o entorno e especialmente com a plataforma rodoviária é agravada pela falta de coordenação entre um conjunto de passagens construídas no local previamente. Com a intenção de serem estruturas indutoras de conexão e organização entre os diferentes edifícios que comporiam o bloco, como identificado pela pesquisadora Gabriela Tenório (2008), os níveis das estruturas horizontais de passagem não coincidem com os níveis térreos dos trechos verticais edificados posteriormente [fig. 52].

Em 1974, no I Seminário de Estudos dos Problemas Urbanos de Brasília, Lucio Costa declarou a respeito: "fiquei chocado [...]: a plataforma, que tem uma determinada quota, existe, está lá desde o começo; entretanto, o setor Sul, esse setor em frente à plataforma, foi construído abaixo da quota da plataforma. Quer dizer, a calçada está num nível e os prédios estão abaixo; 40, 50 centímetros abaixo, sem a ligação com a calçada" (Senado Federal, 1974).

O centro de diversões não se realizou plenamente ao não ser construído um edifício paralelo à plataforma, entre os conjuntos comerciais Norte e Sul e sobre o eixo monumental [fig. X]. Seria um volume baixo, horizontal, com o térreo "vazado em toda a sua extensão, salvo os núcleos de acesso aos pavimentos superiores, a fim de garantir continuidade à perspectiva" (Costa, data. Relatório do Plano Piloto, p. 8). Segundo Maria Elisa Costa e Adeildo Viegas de Lima, que participaram do projeto executivo da plataforma rodoviária, citados por Milton Braga (2010), essa porção central do centro de diversões foi logo abandonada devido a dificuldades estruturais.

Graças a esse conjunto de razões, a escala gregária de Brasília se confi- 

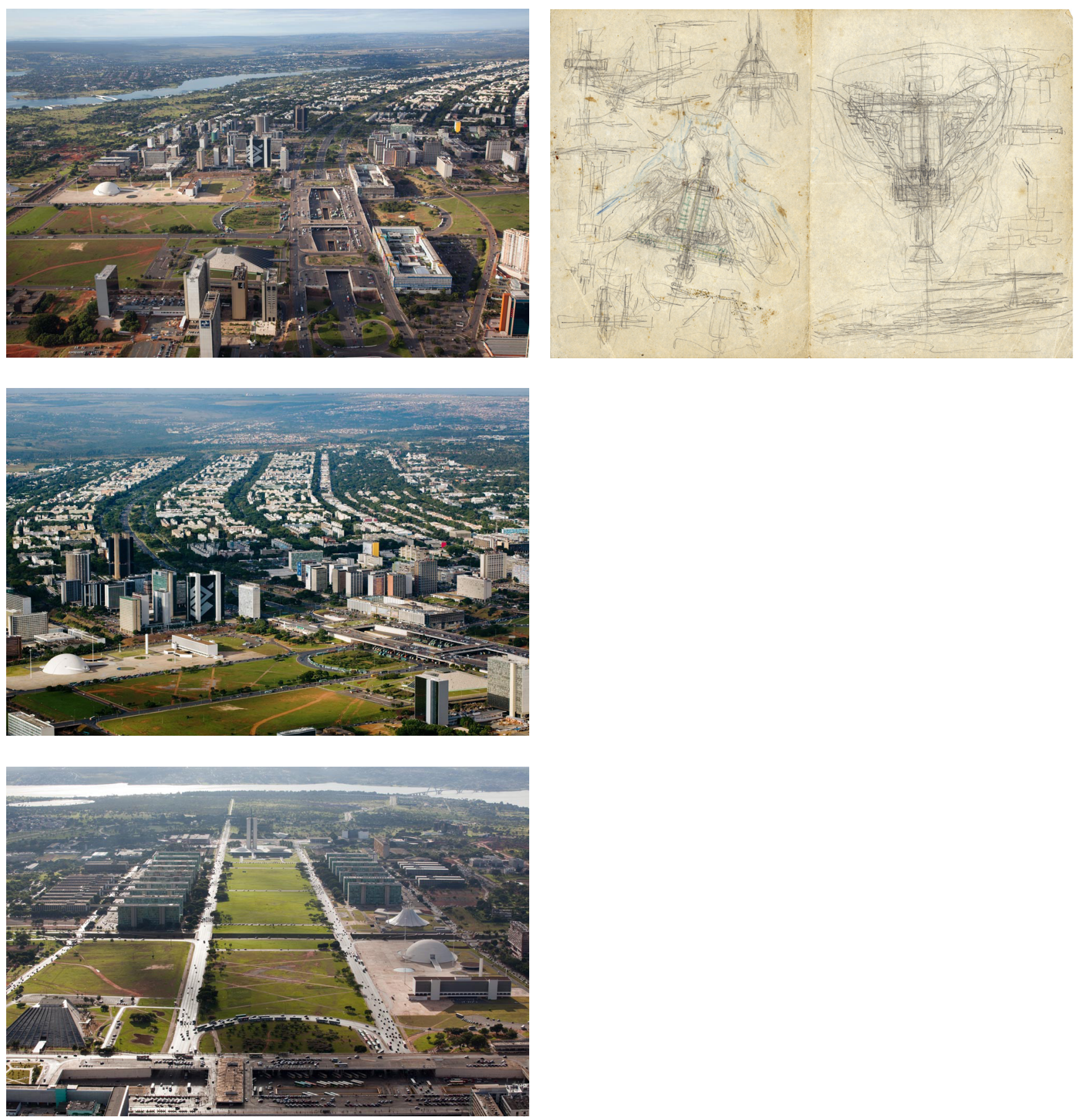

figs. 55 a $\mathbf{5 7}$ - Fotos aéreas dos eixos rodoviário-residencial e monumental, em que se percebe bem a diferença espacial provocada pela curvatura, entre a intimidade dos setores residenciais, face à monumentalidade da perspectiva axial.

fig. 58 - Croquis de Lucio Costa prévios à formalizaçnao da proposta do plano piloto, em 1957. Neste croqui se vêm os eixos já determinados, no entanto retilíneos os dois. Fonte: Acervo Casa de Lucio Costa. 
gurou de modo bastante diverso do imaginado por Lucio Costa. Com os fluxos truncados por erros de projeto ou construção, somados a partidos arquitetônicos deficientes, implicando resolução pouco clara dos sistemas de circulação dos edifícios e sua relação com o entorno, a plataforma teve sua condição de articuladora dos espaços centrais muito limitada.

\section{técnicas rodoviárias}

A extrema inteligência do projeto de Lucio Costa para Brasília foi a de não adaptar o programa e o sítio a modelos genéricos do urbanismo moderno, mas engendrar uma nova cidade, específica a sua função de capital e a sua situação territorial, ajustando-a com delicadeza à topografia. $\mathrm{O}$ desenho, ou a forma, da cidade é determinada por um sistema rodoviário, configurado por dois eixos macroestruturadores que se cruzam em ângulo reto. $\mathrm{O}$ eixo monumental, retilíneo, corre na direção leste-oeste, enquanto o eixo rodoviário-residencial, arqueado, corre no sentido nortesul. Ao longo do eixo rodoviário-residencial, como o próprio nome indica, estão distribuídas as áreas predominantemente residenciais. Ao longo do eixo monumental, estão distribuídos os centros cívico e administrativo, o setor cultural e a estação ferroviária. No cruzamento, o setor de diversões, hoteleiro, comercial. A forma de cruz tem uma extensão determinada, definida, e portanto limita a expansão da cidade. Os futuros e eventuais desenvolvimentos estavam previstos como cidades satélites desde a origem do plano, devendo ser constituídos no entorno do Plano Piloto ao longo do tempo. Essa organização muito simples das funções predominantes está inteiramente estruturada sobre um sistema rodoviário bastante sofisticado, com transposições e retornos que evitam cruzamentos em nível. Por esta descrição, que em parte segue a própria narrativa da memória do Plano Piloto apresentada ao júri do concurso, é possível perceber a importância fundamental do sistema rodoviário na constituição da ideia da cidade, mas não como um sistema racional, abstrato ao qual a cidade se adapta. Pode-se dizer que a estrutura utilizada por Lucio Costa é uma invenção sua, que não segue um modelo, mas que realiza uma determinada cidade, com intenções específicas. 

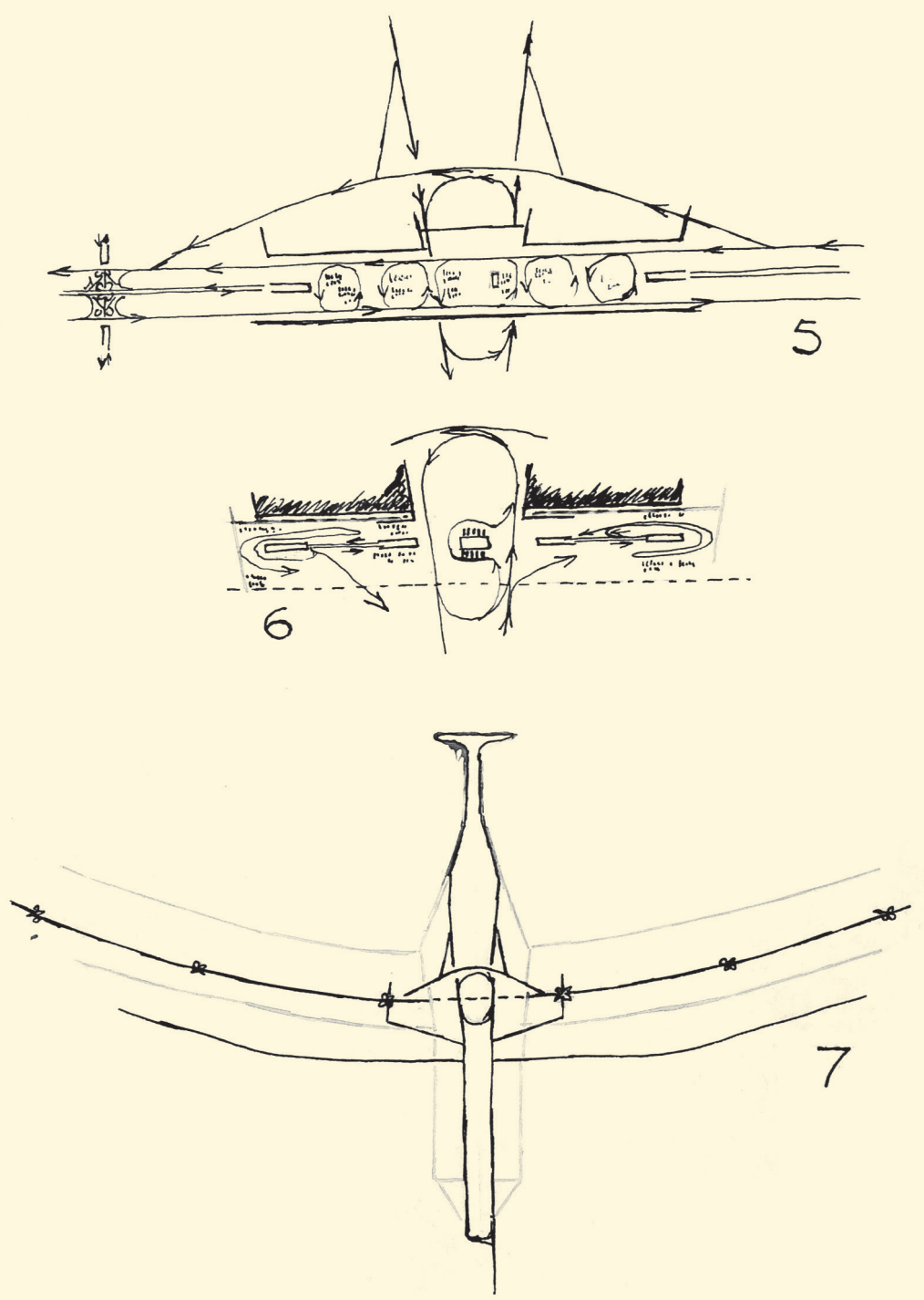

fig. 59 - Croquis integrantes da memória do projeto apresentado ao júri do concurso, em 1957. O de número 5 representa o nível superior da plataforma. $\mathrm{O}$ de número 6 , descreve o nível inferior, da estação rodoviária e o 7 mostra a estrutura básica da cidade, baseada na articulação dos dois eixos. Fonte: Acervo Casa de Lucio Costa. 


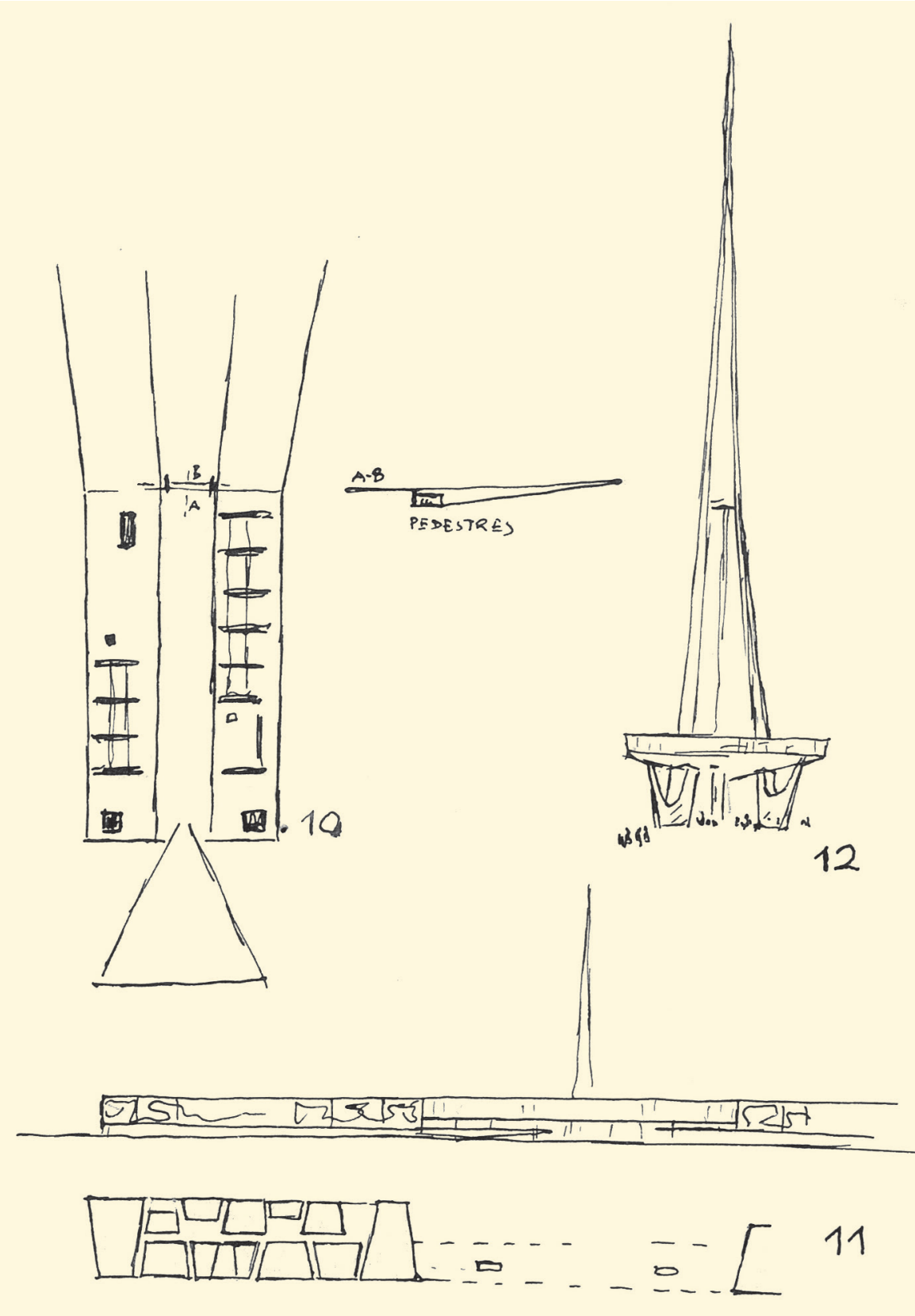

fig. 60 - Croquis integrantes da memória do projeto apresentado ao júri do concurso, em 1957. O de número 11 refere-se aos centros de diversões, com volume central, não edificado, representado com o térreo livre a apenas as caixas de circulação tocando o solo. Fonte: Acervo Casa de Lucio Costa. 

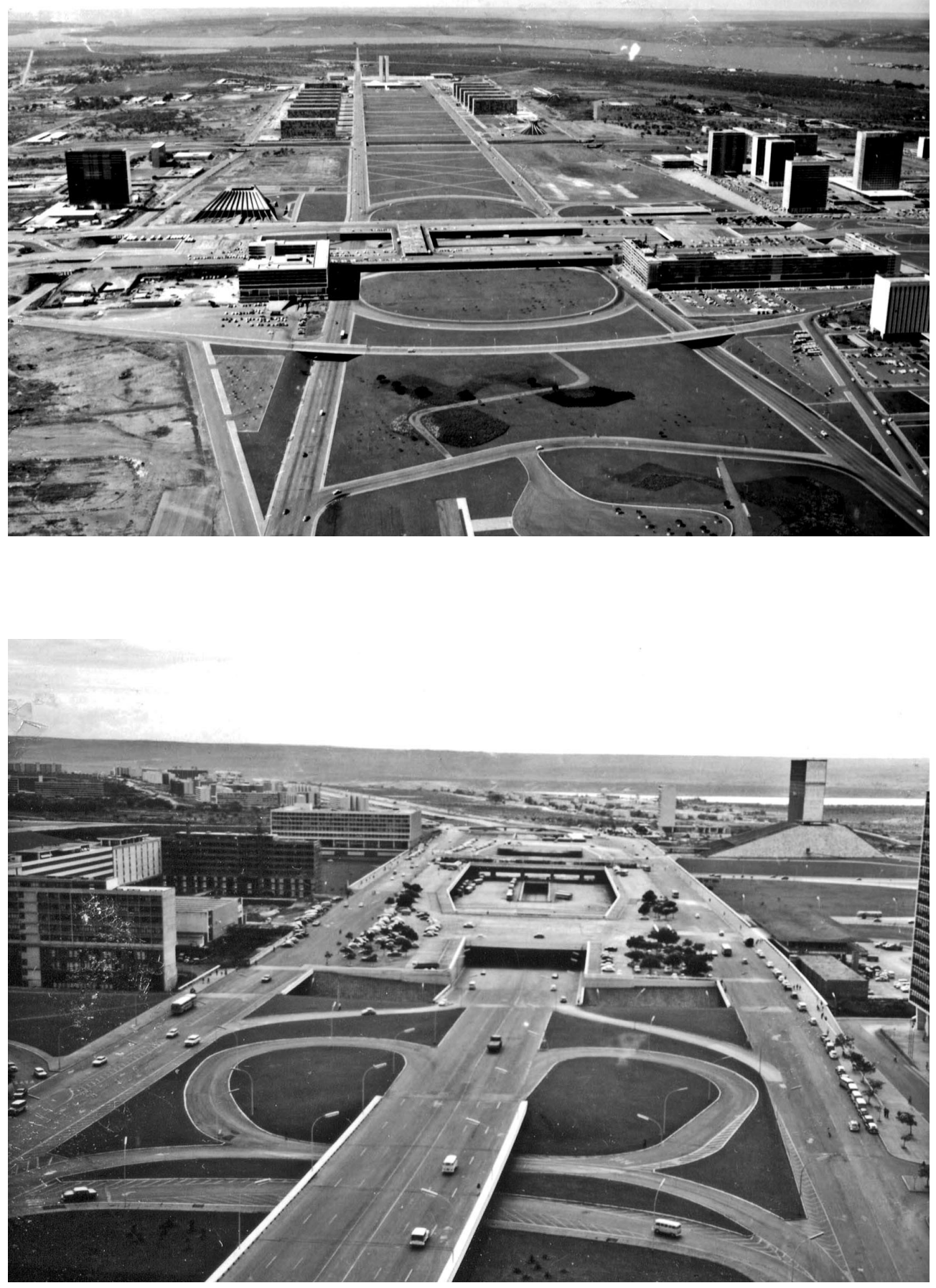

figs. 61 e 62 - Fotos aéreas do sistema rodoviário em 1976, em pleno funcionamento. Apenas a primeira das três etapas de construção do Conjunto Nacional havia sido executada. Fonte: Arquivo Público do Distrito Federal. 
Brasília portanto se afasta dos modelos rodoviaristas modernos. Como exemplo dessa diferença é oportuna a comparação proposta por Matheus Gorovitz entre Brasília e Chandigarh, cidade projetada seis anos antes por Le Corbusier para capital de uma província na Índia. Lá foi estabelecida uma malha regular que constitui o sistema viário e determina um módulo básico de organização das funções urbanas cotidianas. $\mathrm{O}$ centro cívico, destacado dessa malha, é a exceção, à margem dessa estrutura. Como nota Gorovitz, "[E]m Brasília são as funções que, de acordo com sua natureza, determinam o arcabouço estrutural, contrariamente a Chandigarh, onde funções de naturezas diferentes adaptam-se a um arcabouço predeterminado". (Gorovitz, 1985, p. 25)

Sob este enfoque, não é apenas o projeto da plataforma rodoviária, mas a totalidade do sistema rodoviário de Brasília que evidencia a importância do desenho em um projeto de infraestrutura para transcender as funções técnicas, racionais, com a finalidade de criar experiências e urbanidade.

Embora desde o final do século XIX as técnicas rodoviárias fossem já importantes elementos na estruturação urbana e, com a popularização dos automóveis particulares no século XX, a questão ganhasse relevância para o urbanismo, a solução de Lucio Costa é absolutamente original. Ainda que se possa fazer uma conexão entre o eixo rodoviário-residencial e as Parkways de Frederick Law Olmsted, pelo apuro paisagístico, a estrutura projetada por Lucio Costa tem uma complexidade técnica muito superior, e que the confere um caráter urbano próprio. Também as experiências contemporâneas ao projeto de Brasília de Robert Moses em Nova York, com as vias expressas cortando violentamente tecidos urbanos consolidados não se relacionam com a sofisticação das soluções de Lucio Costa, especialmente no cuidado paisagístico demonstrado na preocupação com os espaços de transição entre vias expressas e locais, nos enquadramentos verdes das superquadras. 

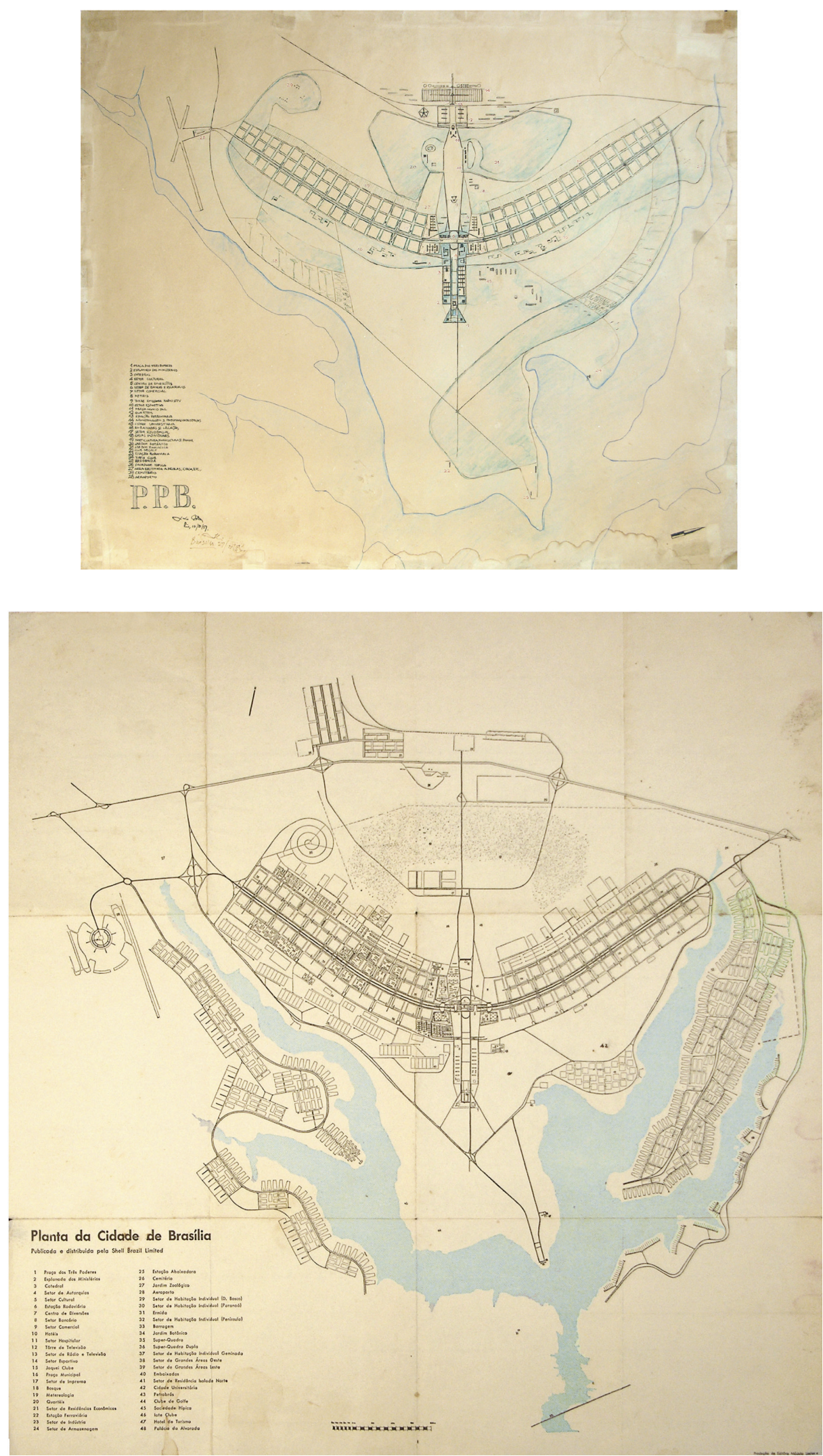

fig. 63 - Planta Geral do Plano Piloto apresentada por Lucio Costa em 1957 ao júri do concurso. Fonte: Acervo Casa de Lucio Costa. fig. 64 - Planta da Cidade de Brasília, encarte da Revista Brasília. Desenho com a conformação final da cidade, com a implantação deslocada em direção leste, como sugerido pelo juri do concurso e com o eixo rodoviário-residencial com uma curvatura mais acentuada, em consequência. Esse ajuste de implantação foi um ponto crucial do desenvolvimento do projeto executivo de urbanismo pois determina o volume de terra a ser manipulado em terraplenos. Fonte: Revista Brasília, 1961. 
A forma e implantação dos eixos foi cuidadosamente estudada por Lucio Costa nos estudos iniciais do Plano Piloto, não apenas em seus aspectos técnicos, mas especialmente paisagísticos. Embora os sistemas de alças e retornos seja eficiente e engenhoso e o dimensionamento das vias suficientemente generoso para suportar um crescimento de fluxo muito superior ao previsto, a implantação dos eixos atende, a meu ver, a questões relacionadas ao desenho, no sentido que venho utilizando aqui. Ou seja, submete-se um sistema técnico a uma intenção de outra ordem que não apenas técnica, sem prejuízo de sua performance. O eixo monumental, retilíneo, permite uma ampla perspectiva barroca, absolutamente apropriada para a finalidade de abrigar a civitas prevista no programa. As largas visuais são favorecidas pela declividade natural do terreno, que permite do ponto de cruzamento dos eixos, uma vista a cavaleiro da Praça dos Três Poderes, constituída como esplanada através de um aterro feito com terra proveniente, em parte, da movimentação de terra necessária para a realização do cruzamento em que se instalou a plataforma rodoviária.

Por outro lado, a curvatura do eixo rodoviário-residencial, que acompanha uma mesma cota da conformação natural do terreno, além da necessária adequação por razões de ordem prática, impede uma perspectiva monumental, e aproxima a paisagem de quem realiza o percurso. Ela torna mais íntima essa relação ao impedir uma apreensão total desse espaço. Nesse sentido, é coerente com o caráter cotidiano das funções ali instaladas, a urbs a que Lucio Costa se refere no memorial.

\section{Projeto e Construção}

O projeto executivo de Brasília foi desenvolvido pela Departamento de Arquitetura e Urbanismo da Novacap, dirigido por Oscar Niemeyer. A divisão de Urbanismo, chefiada por Augusto Guimarães Filho e sediada no Rio de Janeiro, desenvolveu o projeto executivo da cidade. Apesar da relativa autonomia, Lucio Costa acompanhava os trabalhos, como consultor. O projeto da plataforma rodoviária ficou a cargo da Divisão de Urbanismo e contou com a participação dos arquitetos Maria Elisa Costa e Adeildo Viegas de Lima. 


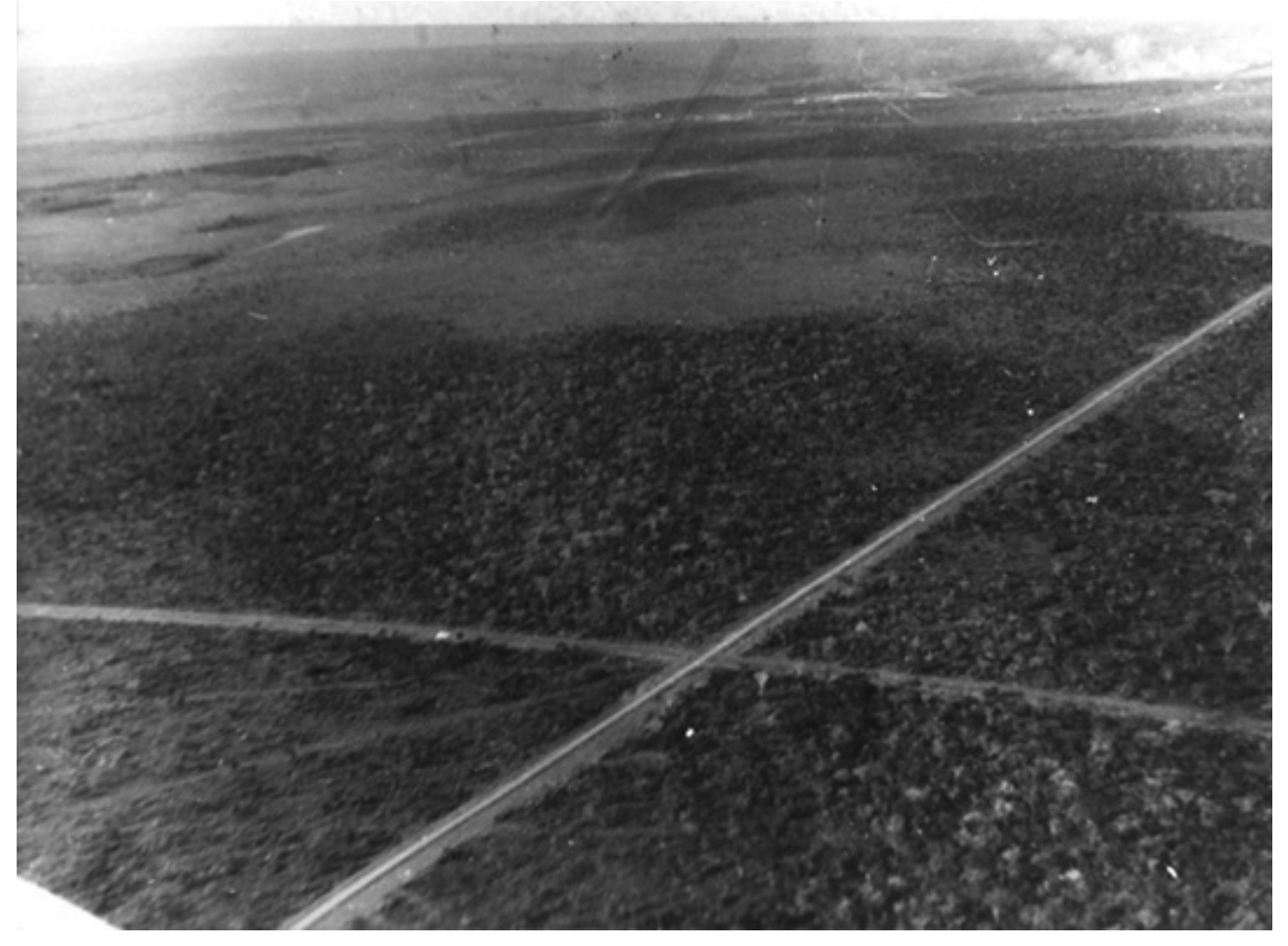

fig. 65 - Cruzamento dos dois eixos, marcados no terreno virgem. Fonte: Arquivo Público do Distrito Federal.

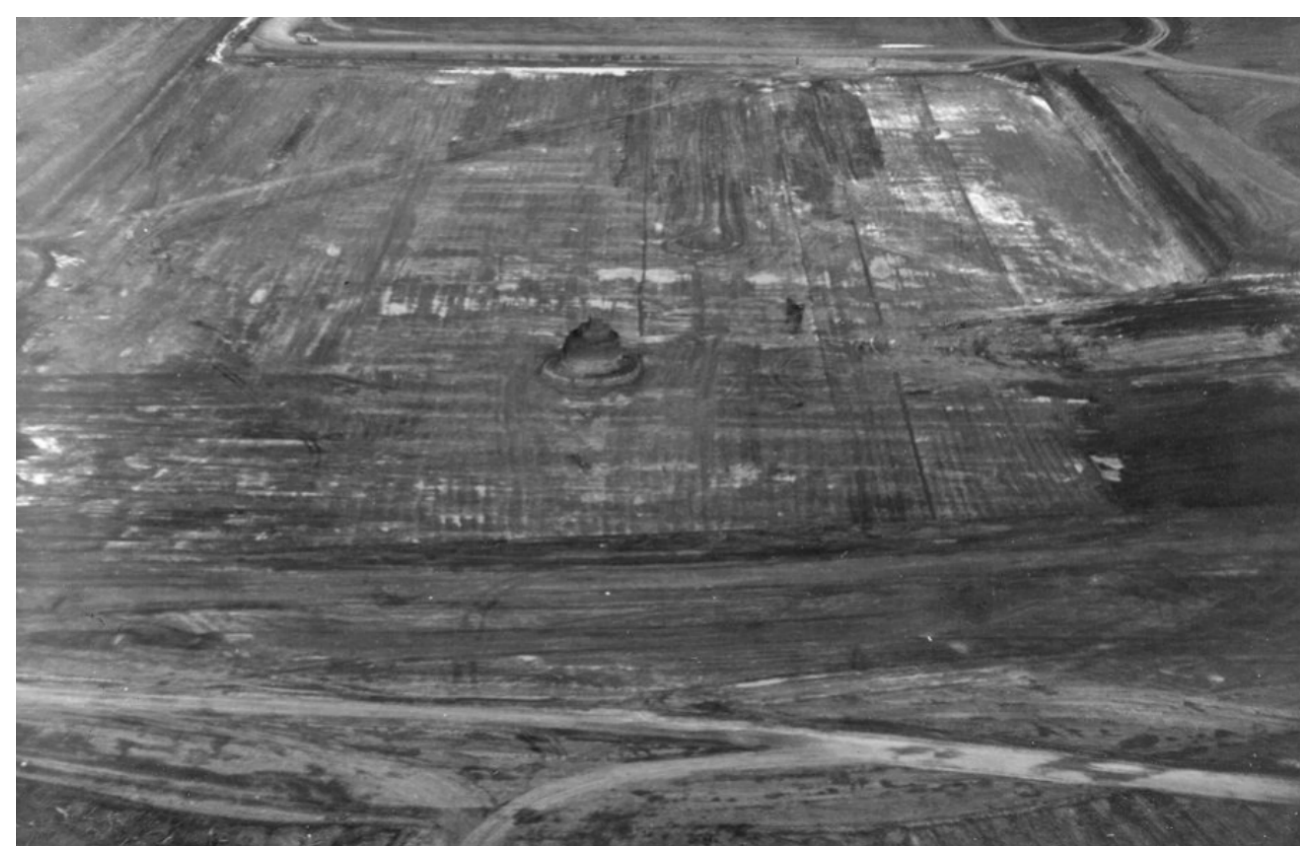

fig. 66 - Início dos trabalhos de terraplenagem no cruzamento dos eixos. O marco zero está no centro da imagem, elevado em relação ao entorno já escavado. Fonte: Arquivo Público do Distrito Federal. 
fig. 67 - Movimentos de terra no eixo monumental. Em primeiro plano o marco zero elevado. Fonte: Arquivo Público do Distrito Federal.

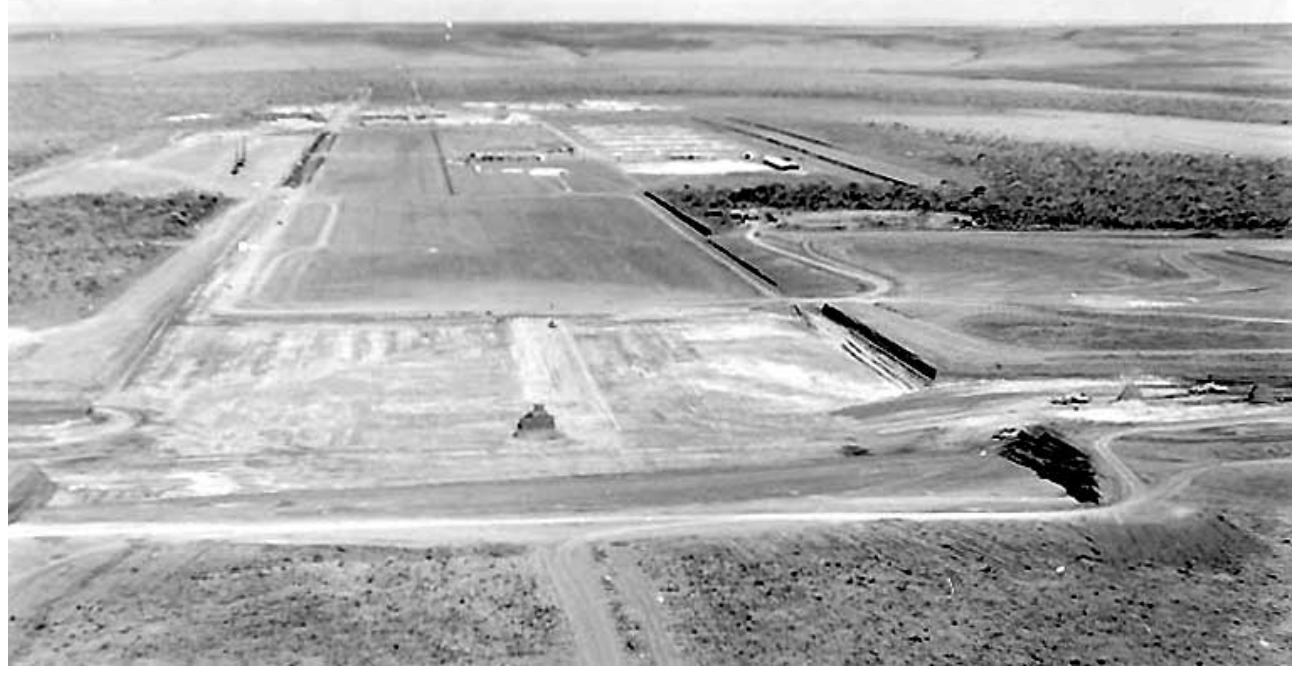

fig. 68 - Os trabalhos de escavação na esplanada do centro de diversões sul, Conic. Fonte: Arquivo Público do Distrito Federal.

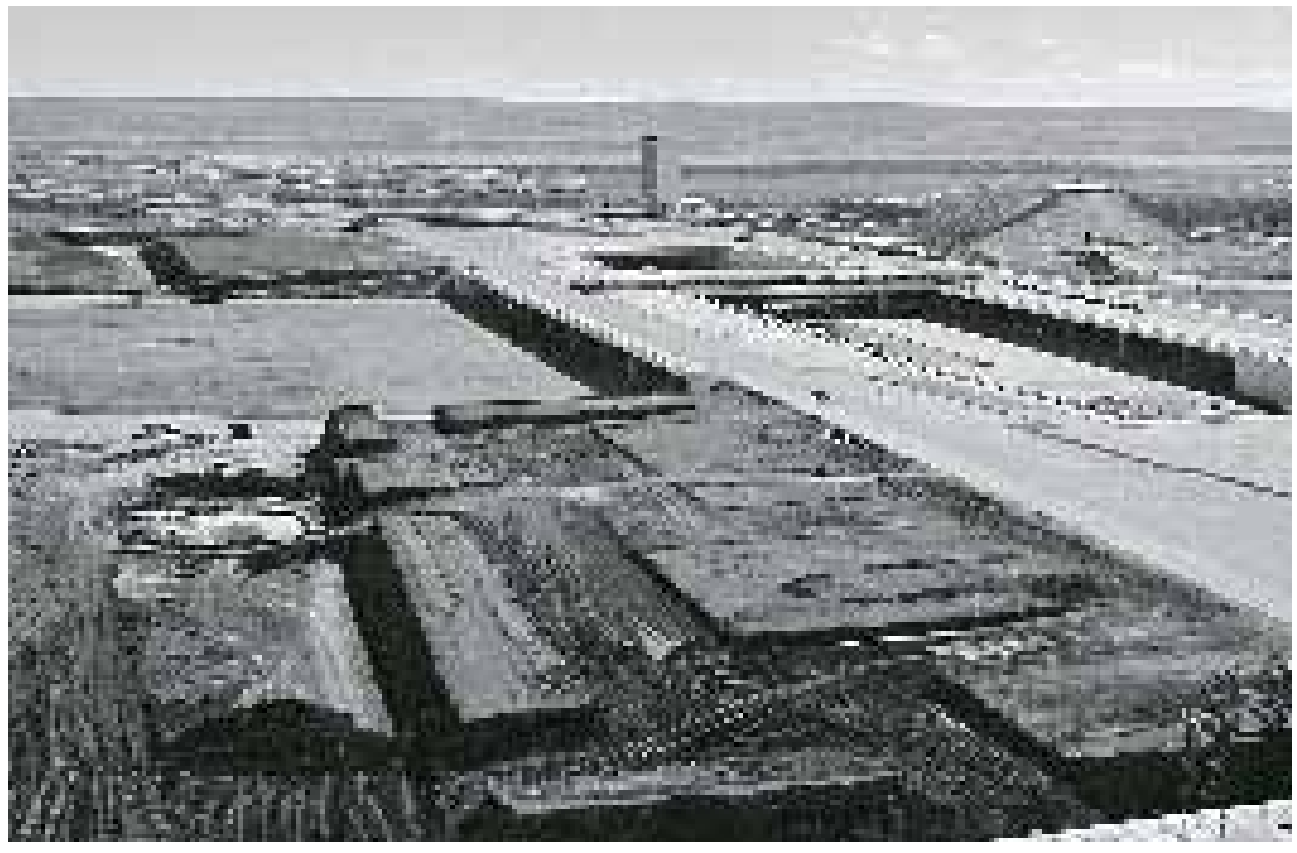




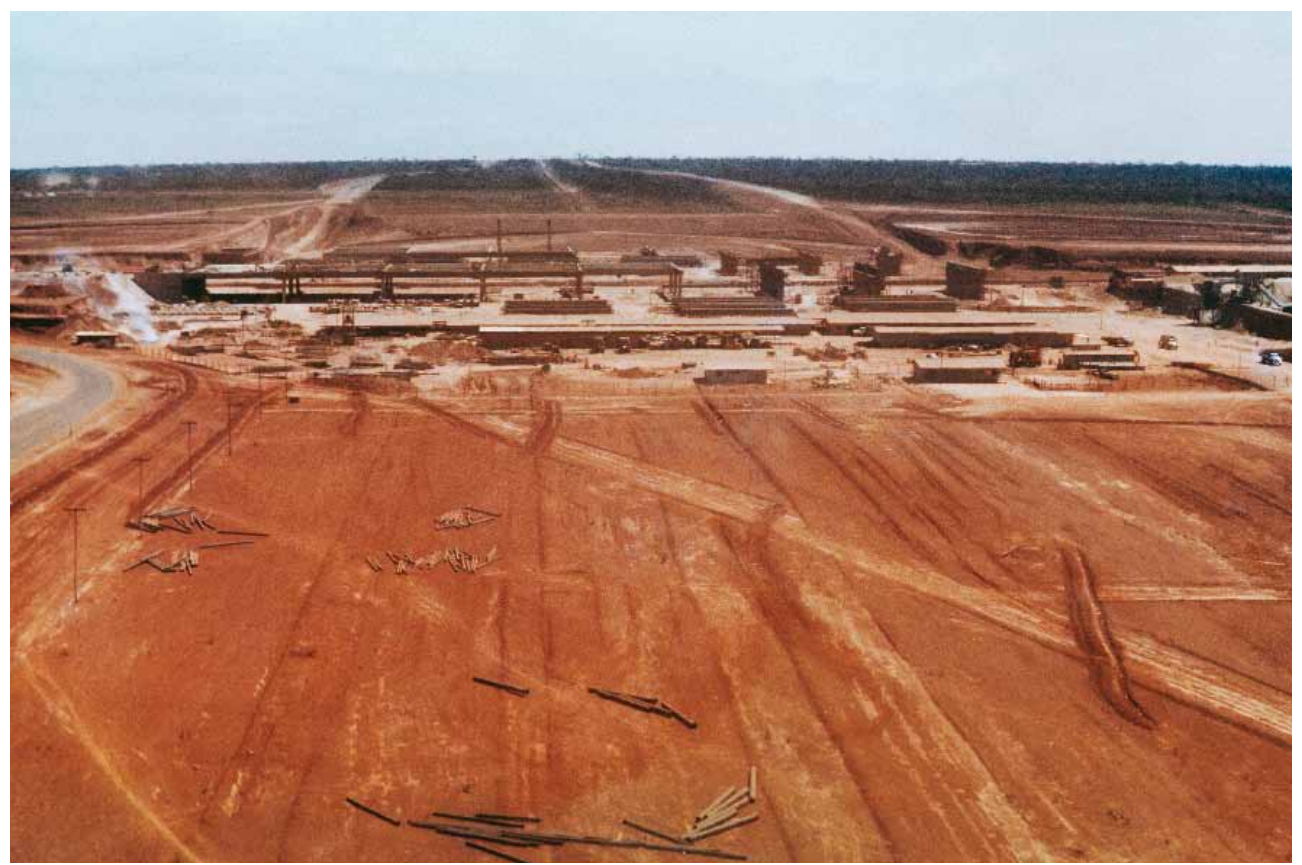

fig. 69 - Vista do eixo monumental em direção Oeste, à estação ferroviária. A estrutura da plataforma já iniciada com os pórticos prinicpais concretados e as vigas prémoldads no piso. Fonte: Arquivo Brasilia.
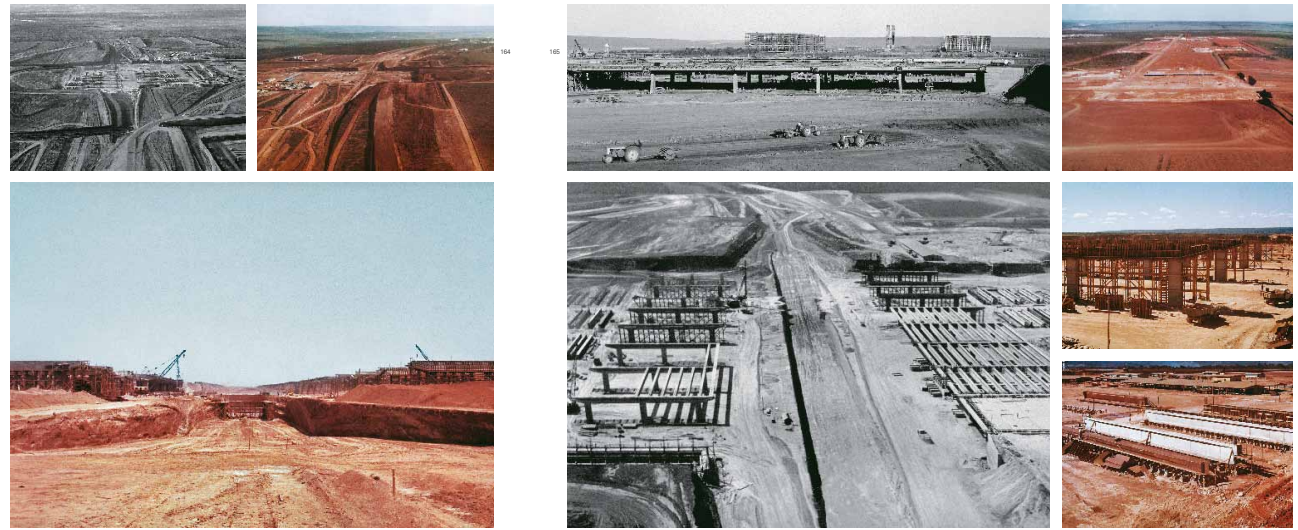

fig. 70 - Páginas do livro Arquivo Brasília em que se vêm vários estágios da construção da plataforma. Fonte: Arquivo Brasília. 
fig. 71 - Estrutura da plataforma em construção. Ao fundo laje do mezanino parcialmente concretado, com pilares centrais prontos. Fonte: Arquivo Público do Distrito Federal.

fig. 72 - Estrutura da plataforma praticamente completa. Ao fundo nota-se o trecho que viria a ser fechado com muros laterais, ainda com pilares e taludes internos. Nessa zona foram estudados estacionamentos adicionais, previstos originalmente. Fonte: Arquivo Público do Distrito Federal.
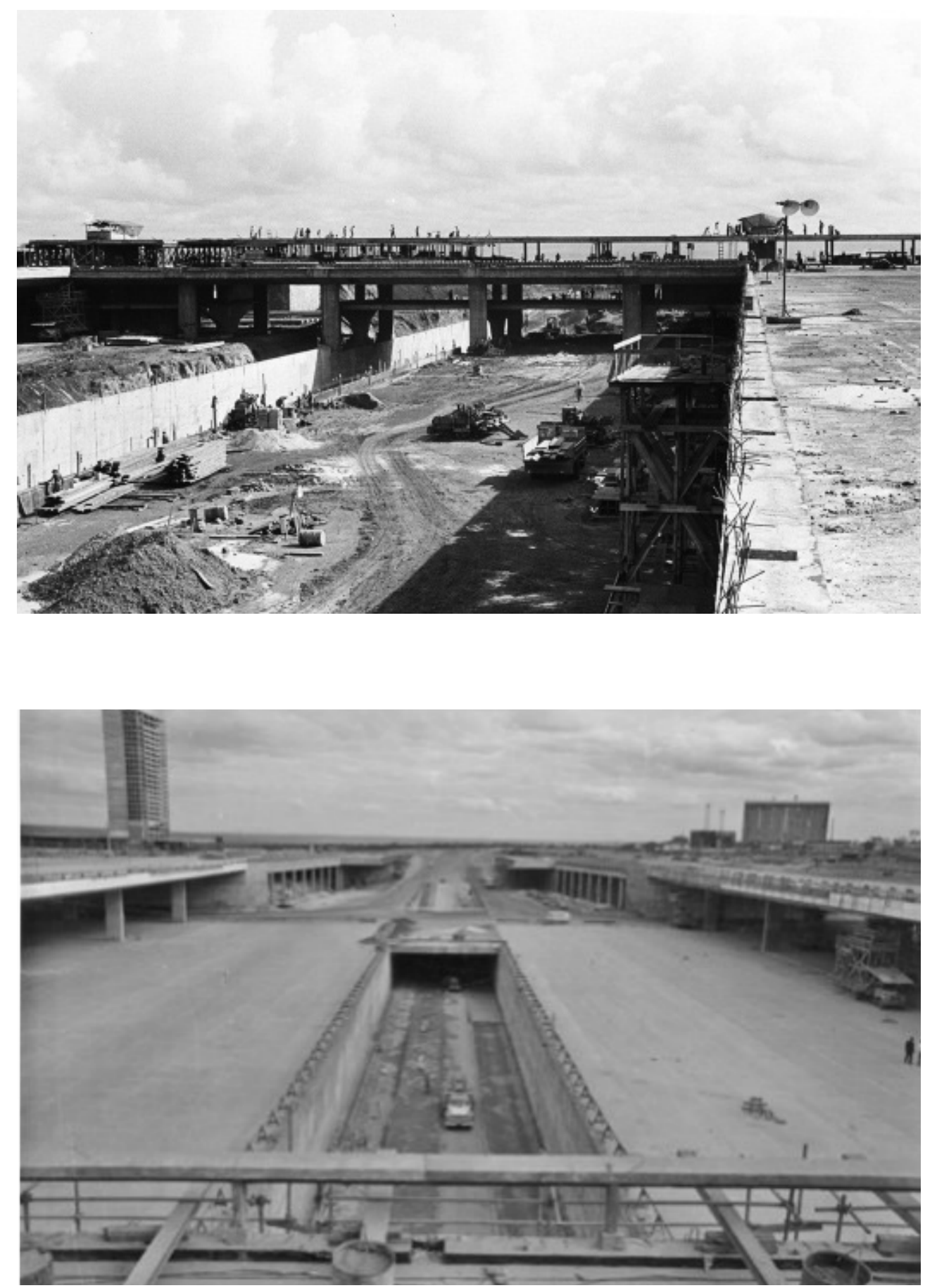


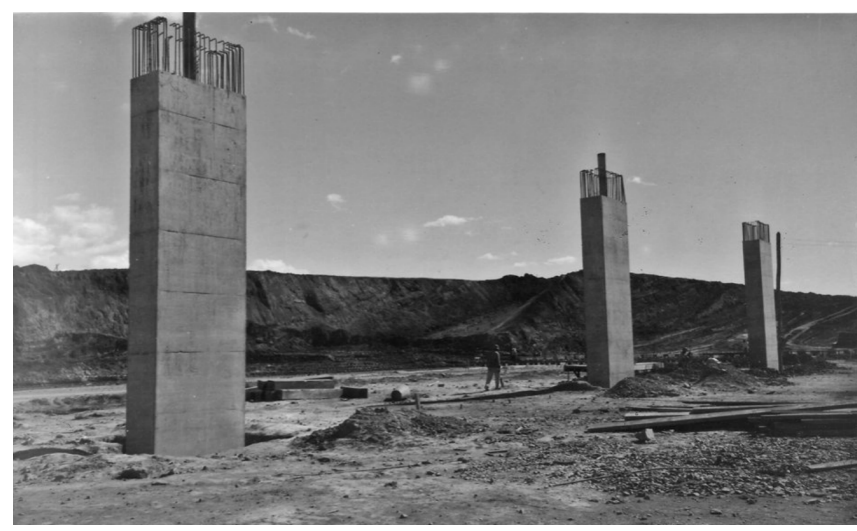

fig. 73 - Conjunto de três pilares de um pórtico estrutural. Fonte: Arquivo Público do Distrito Federal.

fig. 74 - Etapa seguinte: forma e concretagem da viga com 45 metros de extensão, três apoios e dois metros de altura. Fonte: Arquivo Público do Distrito Federal.

fig. 75 - Vigas pré-moldades em canteiro. Fonte: Arquivo Público do Distrito Federal. 


\section{Estrutura}

Os principios estruturais empregados na plataforma rodoviária são muito simples: parte da estrutura é composta por muros de contenção em concreto armado e outra parte é composta por dois conjuntos de oito pórticos em concreto armado moldados in loco, com três apoios cada, vigas transversas pré-moldadas protendidas, também em concreto armado e dois panos de laje horizontal. $\mathrm{O}$ que distingue a estrutura da plataforma são suas dimensões. Os muros, especialmente os que configuram a passagem expressa do eixo rodoviário-residencial, tem até cinco metros de altura. As duas lajes tem 12.500 metros quadrados de área, com 265 metros de comprimento por 45 metros de largura cada. Esses planos são suportados por apenas oito pórticos de cada lado [fig. 74], com três pilares distantes 17.5 metros entre si e cuja viga superior tem dois metros de altura. As vigas protendidas vencem o vão de quase 30 metros entre os pórticos, também com dois metro de altura [fig. 75]. A laje do mezanino, com 23 metros de largura por 165 metros de comprimento é suportada por apenas oito grandes pilares centrais em concreto armado.

\section{Intervenções}

Das poucas intervenções posteriores feitas ao projeto como construído a mais importante foi a implantação das duas praças no nível superior da plataforma, em frente aos Centros de diversões, inauguradas em 1976. As praças, projetadas por Maria Elisa Costa, foram uma tentativa de qualificar o espaço dos pedestres, que segundo Lucio Costa em 1974 "está desarticulado, segmentado" (Senado Federal, 1974).

A partir de 1987, com o tombamento de Brasilia não houve nenhuma alteraçao significativa com exceção da abertura do acesso à estação do Metrô, em 2001, no centro da plataforma Oeste.

Decreto10.829/1987, que se refere à preservação da concepção urbanística de Brasília, o capítulo destinado à escala gregária diz: 


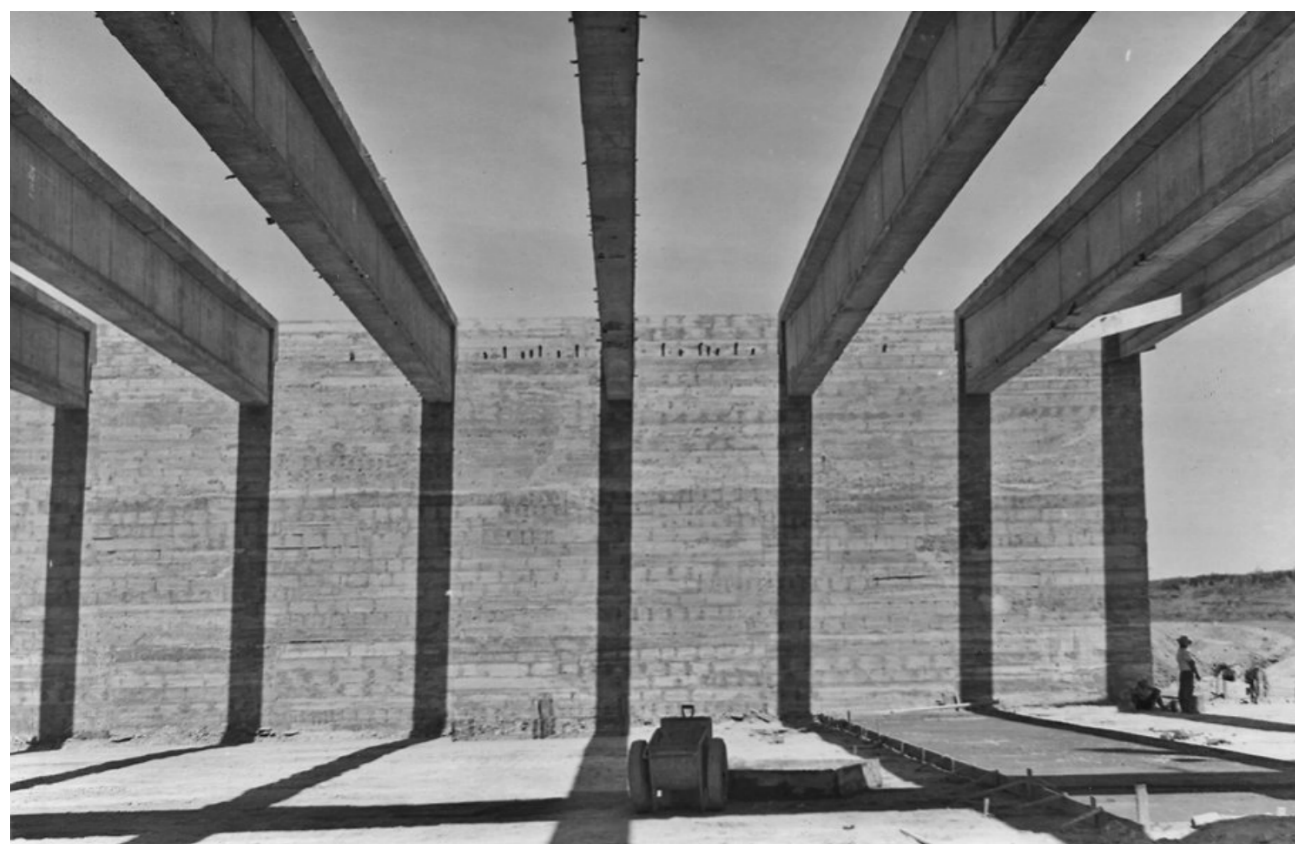

fig. 76 - Grandes vigas, com dois metros de altura," mo arremate da laje principal, junto ao muro de contenção. Fonte: Arquivo Público do Distrito Federal.

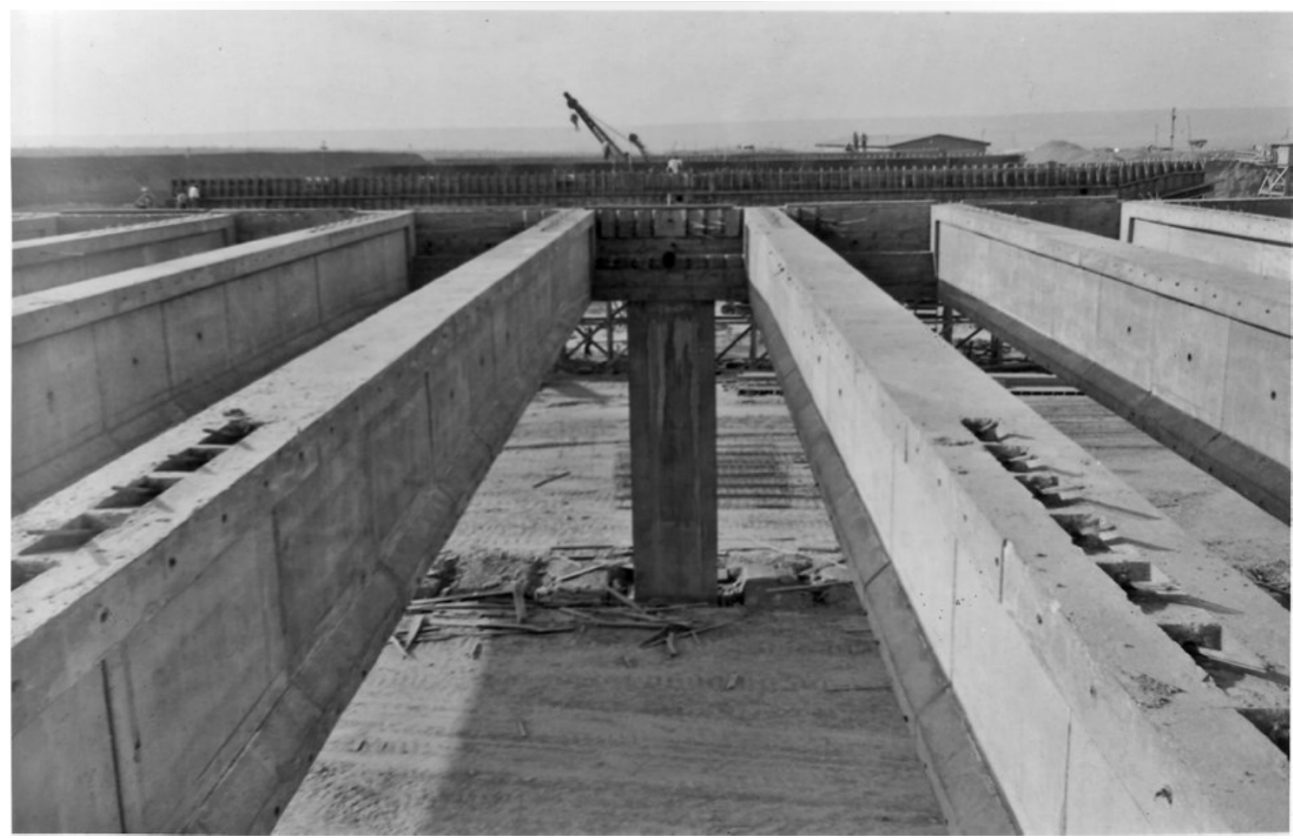

fig. 77 - Vista das vigas pré-moldadas protendidas já instaladas entre pórticos.As vigas vencem mais de 29 metros. Fonte: Arquivo Público do Distrito Federal. 
fig. 78 - Grelha formada por pórticos tri-apoiados e vigas pré-moldadas e protendidas em canteiro. Fonte: Arquivo Público do Distrito Federal.

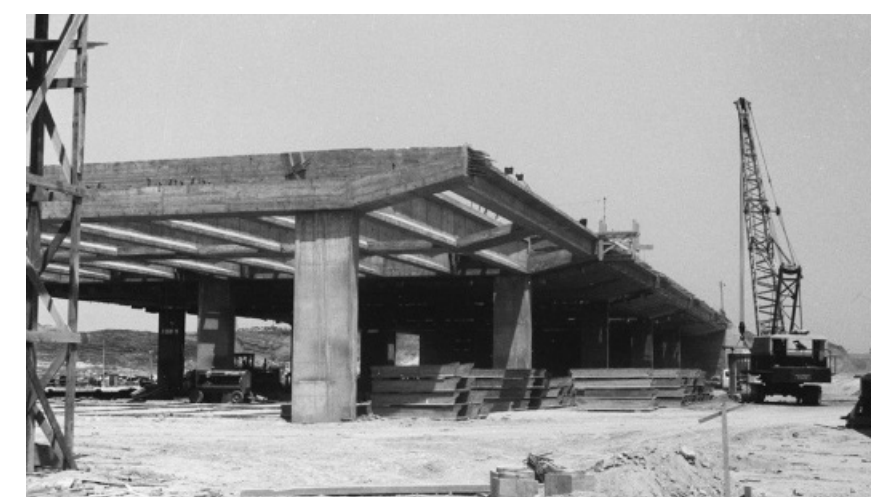

fig. 79 - Sistema estrutural principal sendo coberto por lajes de piso e placas de concreto pré-moldadas na face inferior. Fonte: Arquivo Público do Distrito Federal.

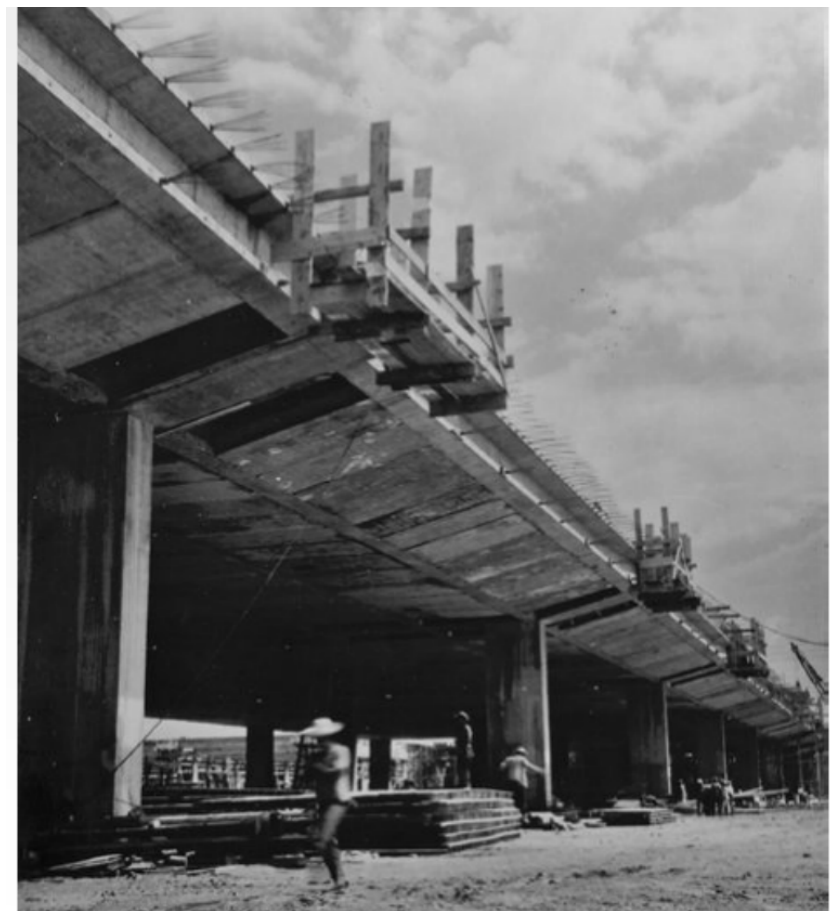

fig. 80 - Vista aérea da esplanada dos ministérios com estrutura da plataforma já concluída ao fundo. Fonte: Arquivo Público do Distrito Federal.

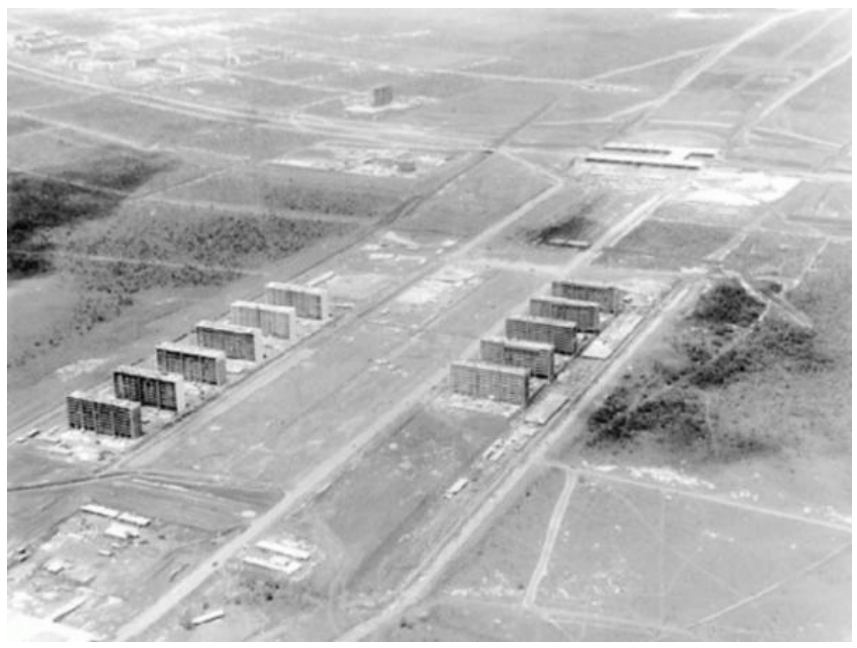




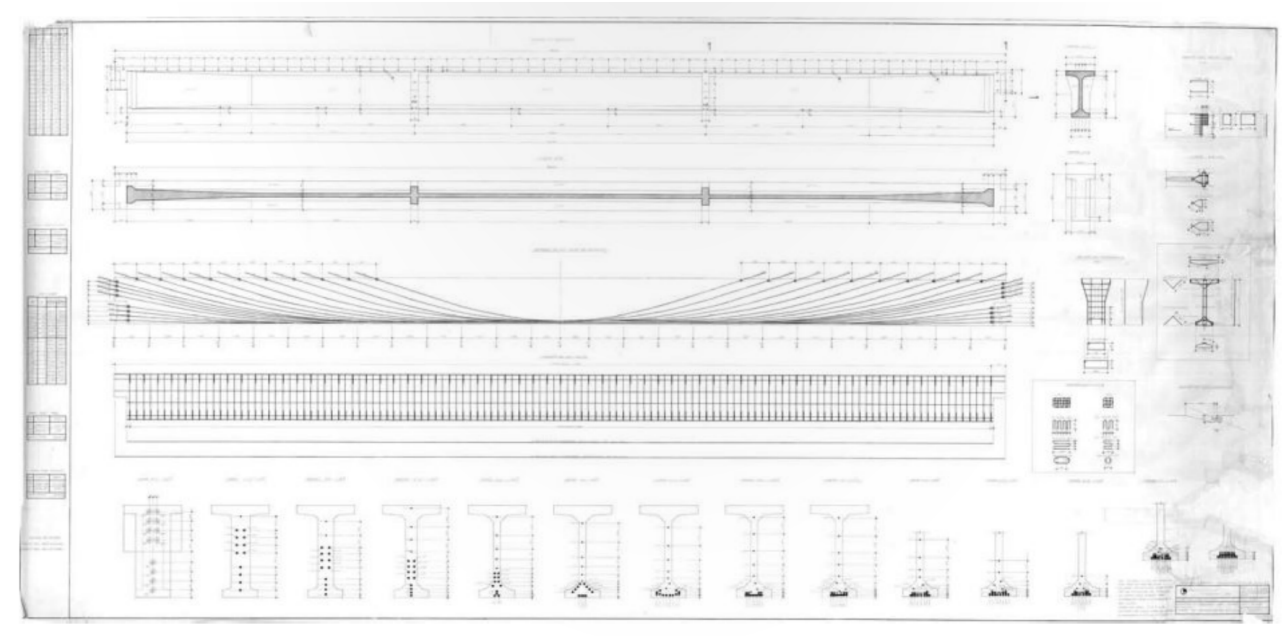

fig. 81 - Detalhamento de armação das vigas prémoldadas protendidas. Fonte: NUDUR/SEDUH.

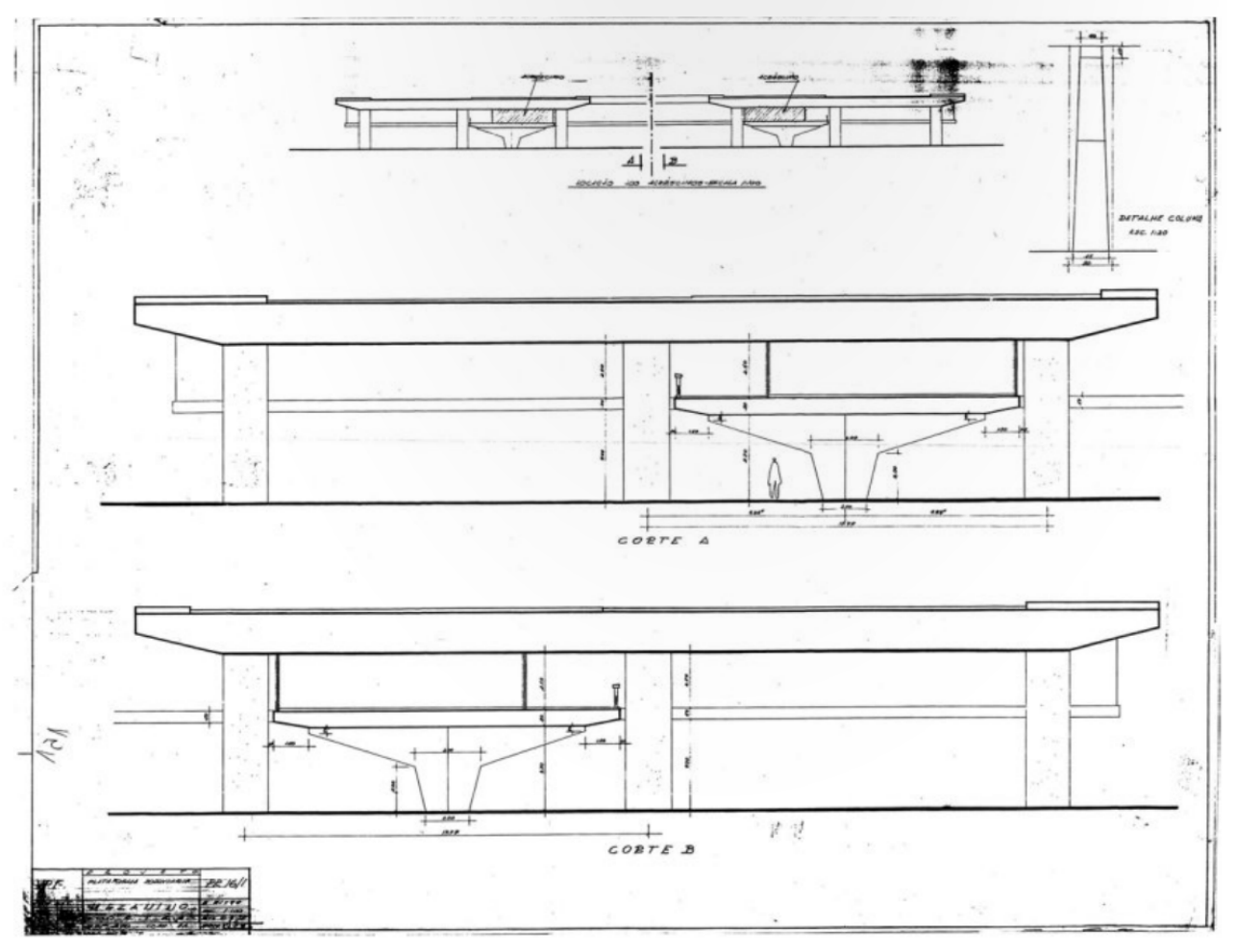

fig. 82 - Cortes de uma proposta rejeitada de extensão, no sentido longitudinal, dos mezaninos. Fonte: NUDUR/SEDUH.

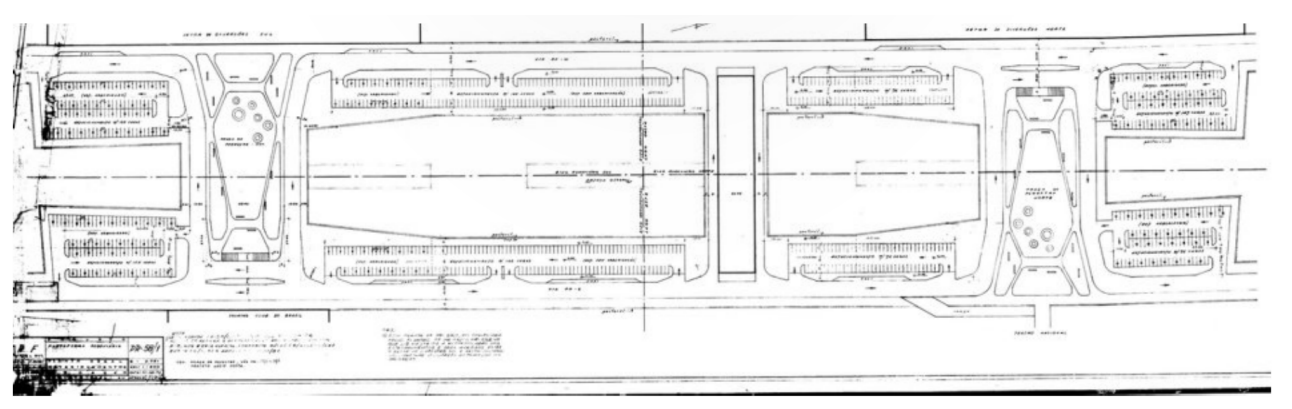

fig. 83 - Planta do nível superior da plataforma com as praças invertidas e relação ao construído. Fonte: NUDUR/SEDUH. 
"Art. 8o. - Para a preservação da escala gregária referida no artigo anterior, serão obedecidas as seguintes disposições:

I - A Plataforma Rodoviária será preservada em sua integridade estrutural e arquitetônica original, incluindo-se nessa proteção as suas praças atualmente implantadas defronte aos Setores de Diversões Sul e Norte;

II - Os Setores de Diversões Sul e Norte serão mantidos com a atual cota máxima de coroamento, servindo as respectivas fachadas voltadas para a Plataforma Rodoviária, em toda a altura de campo livre, para instalação de painéis luminosos de reclame, permitindo- se o uso misto de cinemas, teatros e casas de espetáculos, bem como restaurantes, cafés, bares, comércio de varejo e outros propiciem o convívio público;

III - Nos demais setores referidos no artigo o gabarito não será uniforme, sendo que nenhuma edificação poderá ultrapassar a cota máxima de $65.00 \mathrm{~m}$ (sessenta e cinco metros), sendo permitidos os usos indicados pela denominação dos setores de forma diversificada, ainda que se mantenham as atividades preconizadas pelo Memorial do Plano Piloto. 
conclusão 


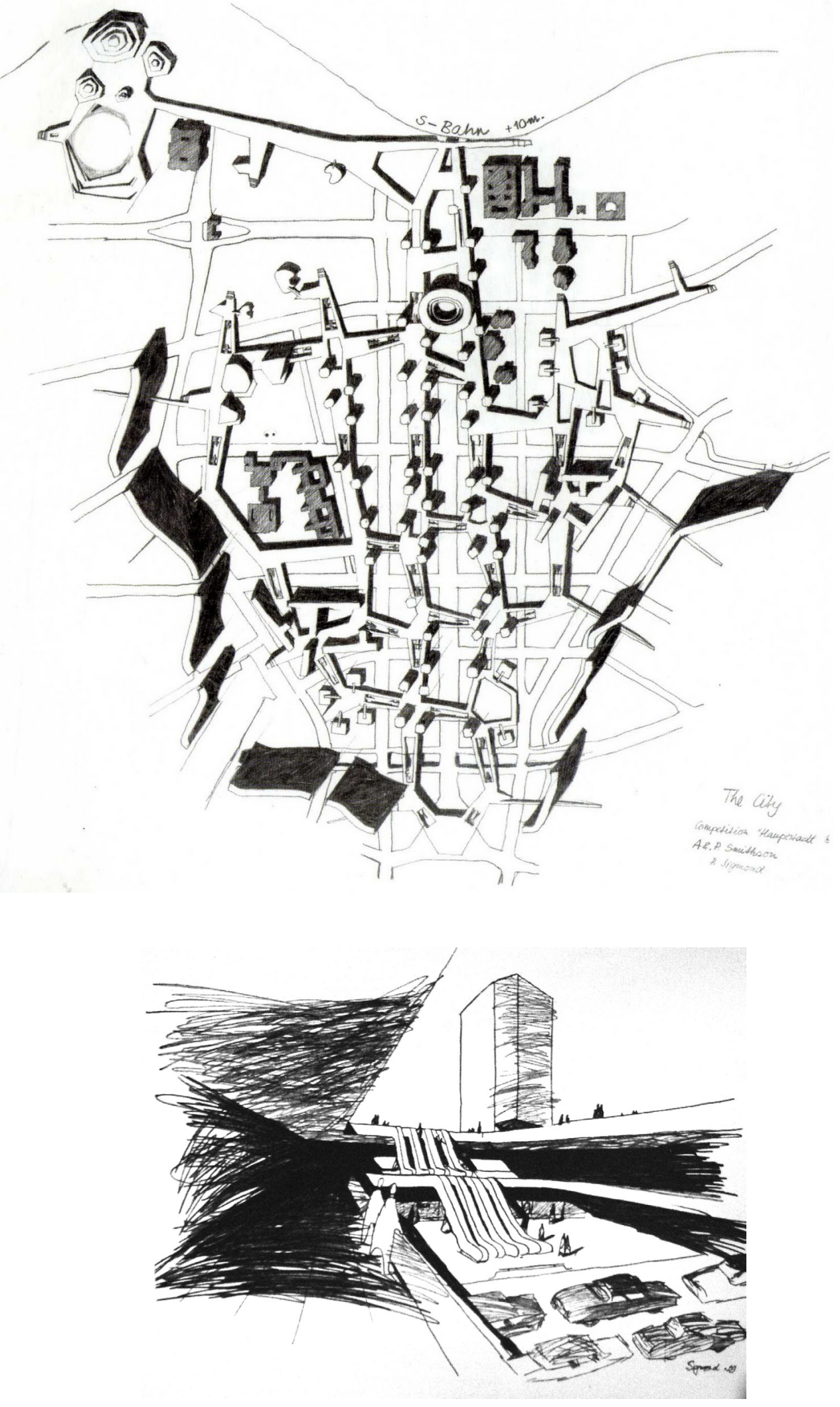

figs. 84 e 85 - Planta da proposta de Alison e Peter Smithson para o concurso para o Haupstadt, em Berlim, de 1958. Trata-se de um sistema de plataformas aéreas de circulação pedestre, sobreposto ao sistema de circulação de veículos. Essa redes de caminhos articularia uma série de edifícios e funções, criando uma espacialidade muito similar à obtida por Lucio Costa na plataforma de Brasília. Fonte: Urbanism as a Void, 2009. 


\section{conclusão}

A análise do projeto, somado aos comentários e relatórios do seu autor corroboram as impressões de incompletude do centro de Brasília. Como visto na análise do estado atual do conjunro construído há uma deficiência notável em sua função de articulador dos diferentes setores e com isso o grau de urbanidade do que deveria ser o ambiente de maior vitalidade de Brasília é baixo.

Por outro lado, como peça do sistema infraestrutural de transporte público, ela não só desempenha um papel fundamental, aí sim de articuladora de diferentes sistemas, como conseguiu suportar razoávelmente bem uma acréscimo de demanda muito superior ao imaginado.

As razões pelas quais ela falha ou tem êxito podem ser, como visto aqui, creditadas a dispositivos de desenho. A potencialidade latente de se tornar um promotor de urbanidade poderia ser realizada com algumas intervenções no ambiente construído, como transposições pedestres mais eficientes e com o incentivo à ocupação consequente de espaços ociosos, que poderiam ser adaptados a novos usos, como a Casa de chá, por exemplo.

Essas características da plataforma tem um valor histórico se comparada a experiências da mesma natureza, em lugares e tempos diferentes nos últimos 50 anos. E apontam para novas formulações e procedimentos que tem surgido como alternativas à procura de uma atuação mais efetiva das disciplinas ligadas à cidade, na produção do ambiente urbano.

Houve nos últimos 10 anos, em diversos meios acadêmicos no mun- 


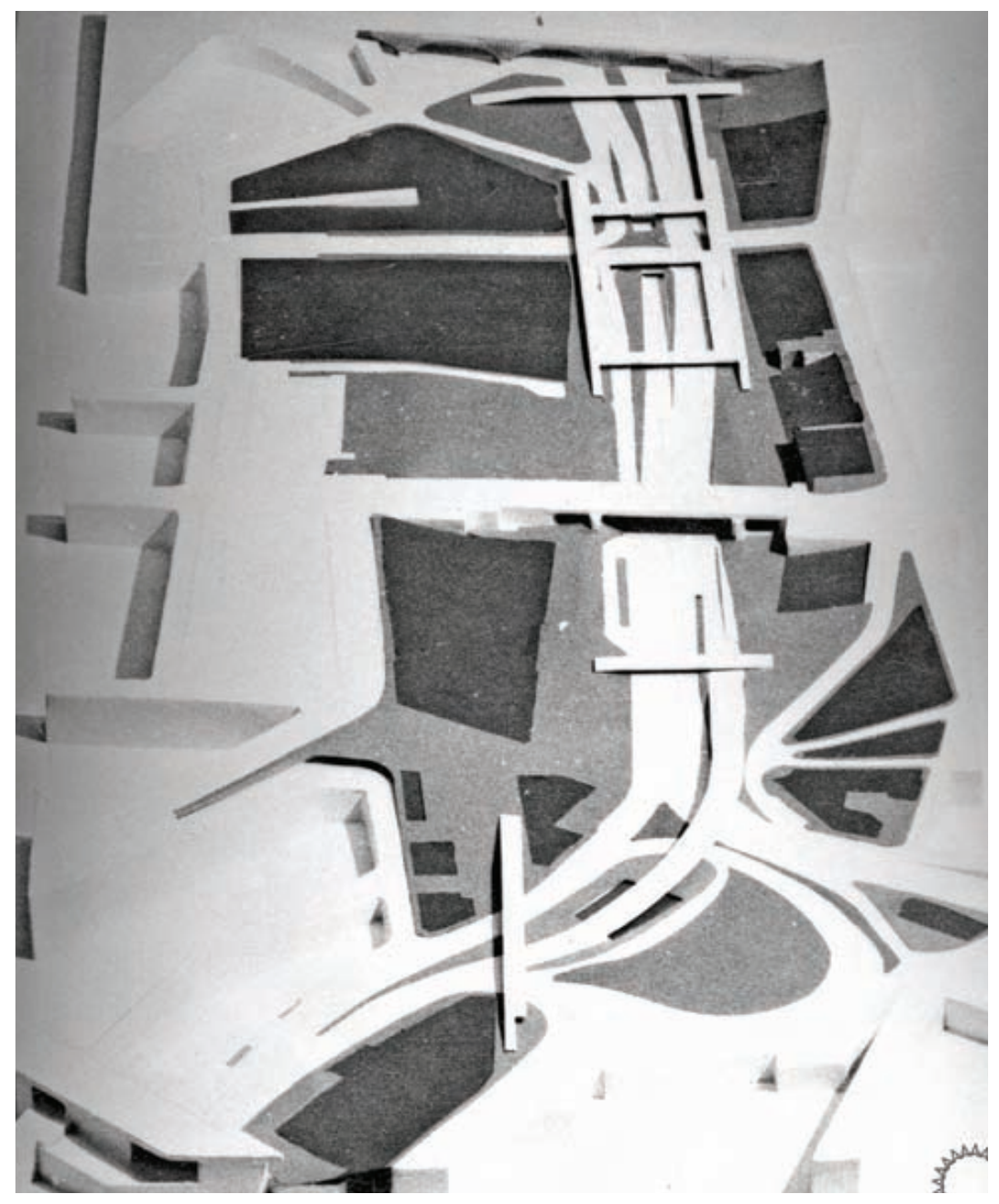

fig. 86 e 87 - Projeto para reformulação do sistema de transportes sobre rodas em São Paulo, proposto por Vilanova Artigas, na década de setenta. Propunha uma plataforma de transposição do vale do Anhangabaú, articulando as cotas alta e baixa da cidade e os fluxos pedestres e veiculares. Fonte: Acervo Villanova Artigas, FAUUSP.

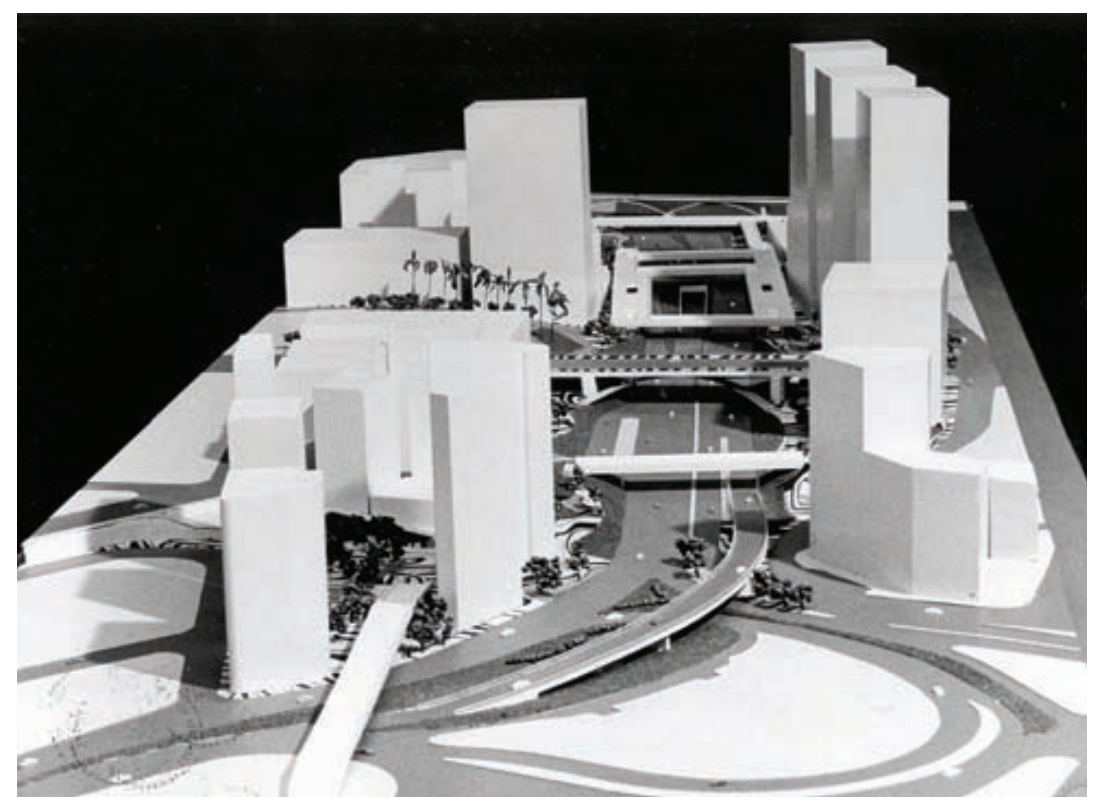


do, uma emergência dos temas e questões abordados nesta dissertação. As disciplinas e práticas materiais envolvidas na produção do espaço têm se confrontado com a ineficácia dos instrumentos tradicionais de intervenção em ambientes urbanos. Uma das iniciativas nesse sentido produziu o termo "Landscape Urbanism" - cunhado por Charles Waldheim, da Universidade de Illinoys, Chicago - que, a partir da disciplina do paisagismo, tem realizado um conjunto de projetos e pesquisas acadêmicas que buscam redefinir as fronteiras de sua atuação (Waldheim, 2006). Também a Architectural Association, em Londres, tem formado grupos de pesquisa no campo. Em Harvard, na Graduate School of Design, formou-se um grupo oriundo da disciplina do Urbanismo, que produziu estudos chamados de Ecological Urbanism (Mostavafi, 2010). Proveniente da disciplina da arquitetura, em Princeton, Stan Allen coordenou estudos acerca dos chamados "Landform Buildings" que promoveram a discussão sobre edifícios que tem impacto urbano relevante, em função de características como tamanho, indeterminação programática etc. (Allen, 2011).

Apesar das matrizes disciplinares diversas, as abordagens tem diversos pontos em comum: reivindicam a incorporação do território como escala de intervenção, a importância de considerar a infraestrutura e seus procedimentos de projeto como principal instrumento de atuação, a necessidade de borrar as fronteiras entre as disciplinas que atuam em ambientes urbanos e, por fim, como conseqüência, discutem a superaração da distinção entre natural e artificial.

Em um texto de 2006, Elisabeth Mossop avalia por exemplo o potencial da associação entre projetos paisagísticos, de infraestrutura e de planejamento urbano em experiências com precedentes tão distantes quanto 1880, como o Emerald Necklace, em Boston, projeto desenvolvido por Frederick Law Olmested nos Estados Unidos. Alguns dos pontos de seu texto "Landscapes of Infrastructure", em The Landscape Urbanism Reader, de 2006, ela diz "the issue of territoriality is instrumental in our current dilemma of how to deal with contemporary urban development, and 

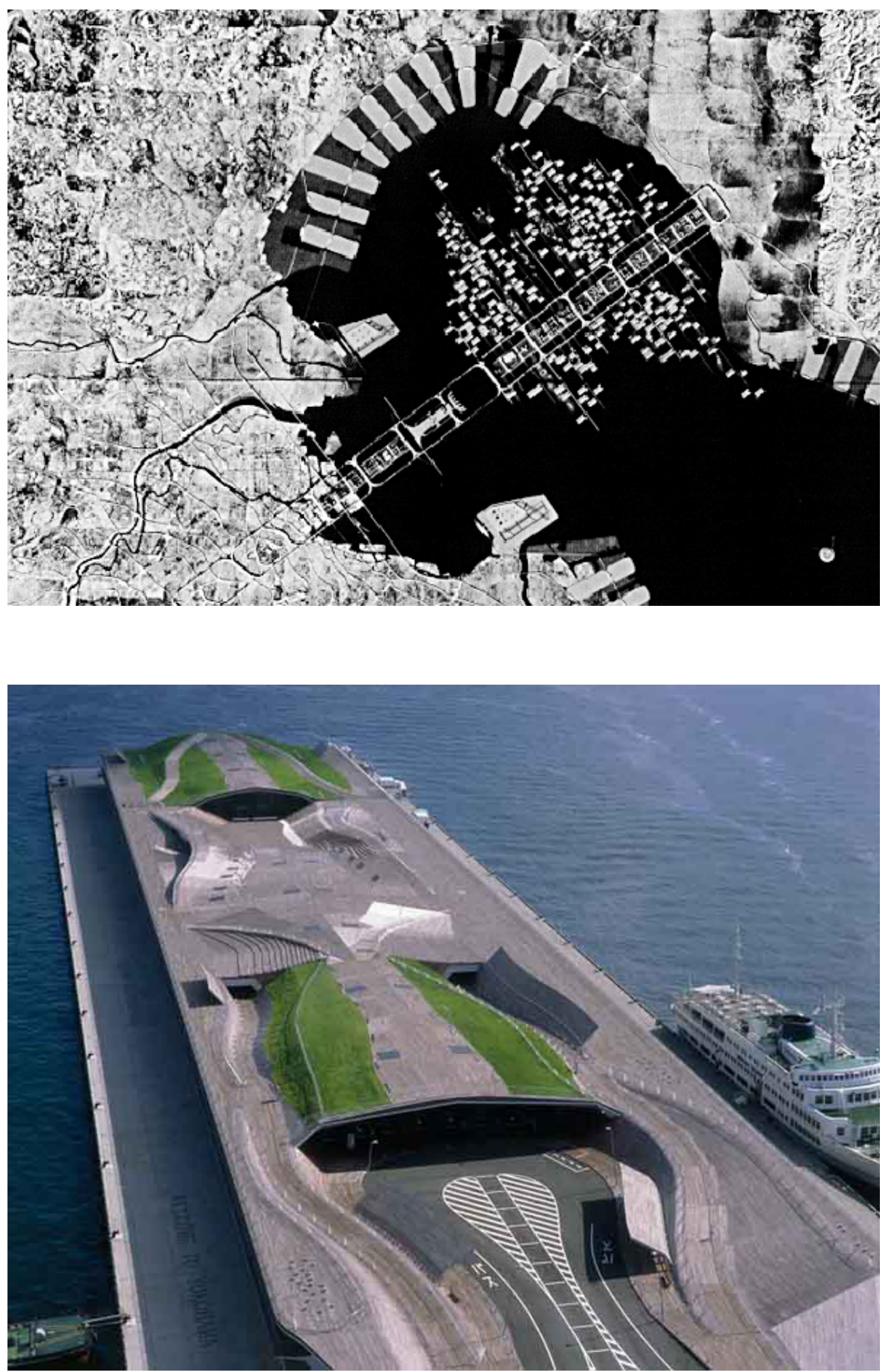

fig. 88 - Projeto de Kenzo Tange para a baía de Tókio, composto por um grande eixo viário de articulação. Proposto nos anos sessenta, é o exemplo máximo do pensamento das megaestruturas. Fonte: Megaestruturas, R. Banham,1975. figs. 89 - Terminal marítimo de Yokohama, de 2001. Uma peça infraestrutural com multiplos programas associados e que se realiza pela intensa articulação espacial promovida por uma superfície contínua, que opera transposições entre diferentes fluxos. É portanto um projeto de arquitetura que opera com os disositivos dos sistemas infraestruturais. Fonte: Alejandro Zaera-Polo. 
disciplinary divisions have only served us ill in coming to terms with the complexity of current patterns of urbanization." E, "The issue of boundaries is also relevant in revisiting the question of the separations of humans from nature and the confusion in discussing the urban lanscape often caused by equating "landscape" with nature" (Mossop, 2006, p. 170). Nesse mesmo livro, Chris Reed faz um resumo do debate elencando 4 pontos fundamentais: 1. Blurring of distinctions between tradition fields of practice; 2. Appropriation of Infrastructural strategies and ecological tactis; 3. Activation of multiple, overlapping networks and dynamic coalitions of constituencies; 4. Catalytic and responsive operations. (Reed, 2006, p. 282)

$\mathrm{Na}$ introdução a Landform Buildings, Stan Allen elenca alguns pontos fundamentais para conceituar a sua aproximação, como: "Landform Building reworks the opposition between object buildings and landscape fields to create productive transformations" (Allen, 2011, p. 34). No mesmo livro, considerando a baixa qualidade do espaço urbano disperso, Kenneth Frampton constata que "urban design today manifests itself primarily as an academic discourse. It is a field that is largely impotent when it comes to actual urban development" (Frampton, 2011, p. 238), para por fim reivindicar a importância da arquitetura, ou desenho, como forma de atuação em escala metropolitana.

Ou seja, é possível apreender que grande parte da prática e da produção intelectual recentes sobre as cidades, de modos diversos e por caminhos próprios, aponta para um necessário processo de redefinição conceitual e disciplinar que tenha como consequência a indistinção entre a natureza e o espaço construído, a criação de ecossistemas complexos, híbridos técnicos e naturais, pensados de modo sistêmico e em escala territorial. Essas práticas supõem novos arranjos profissionais como modo de atuar de forma efetiva nas cidades contemporâneas. E é também notável a incorporação ao discurso disciplinar uma alta dose de pragmatismo que se revela na preocupação recorrente de equacionar ou problematizar os mecanismos de implantação e gestão dos projetos, mesmo depois de implantados, em uma abordagem que considera o 


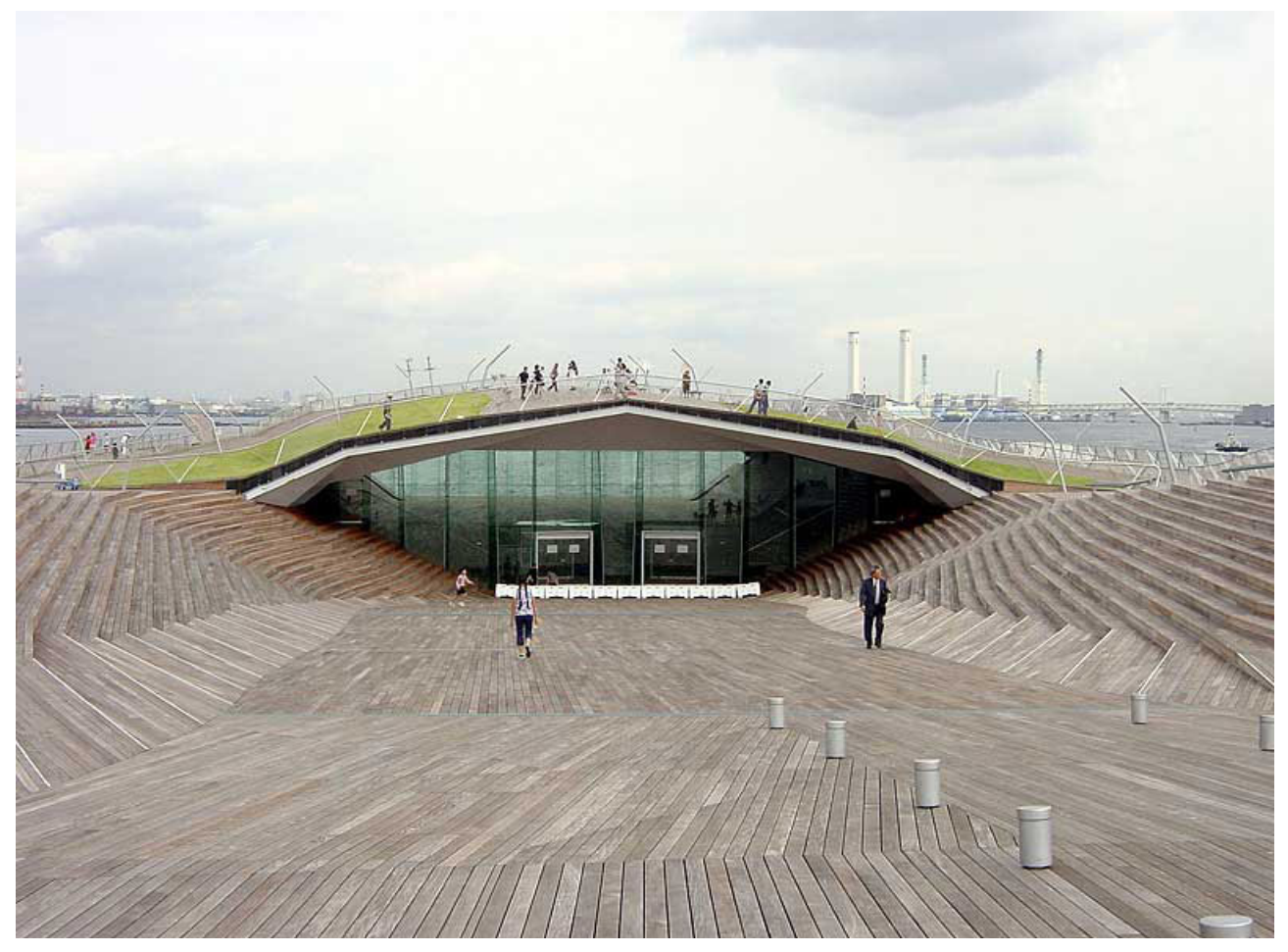

fig. 90 - Terminal marítimo de Yokohama, de 2001.

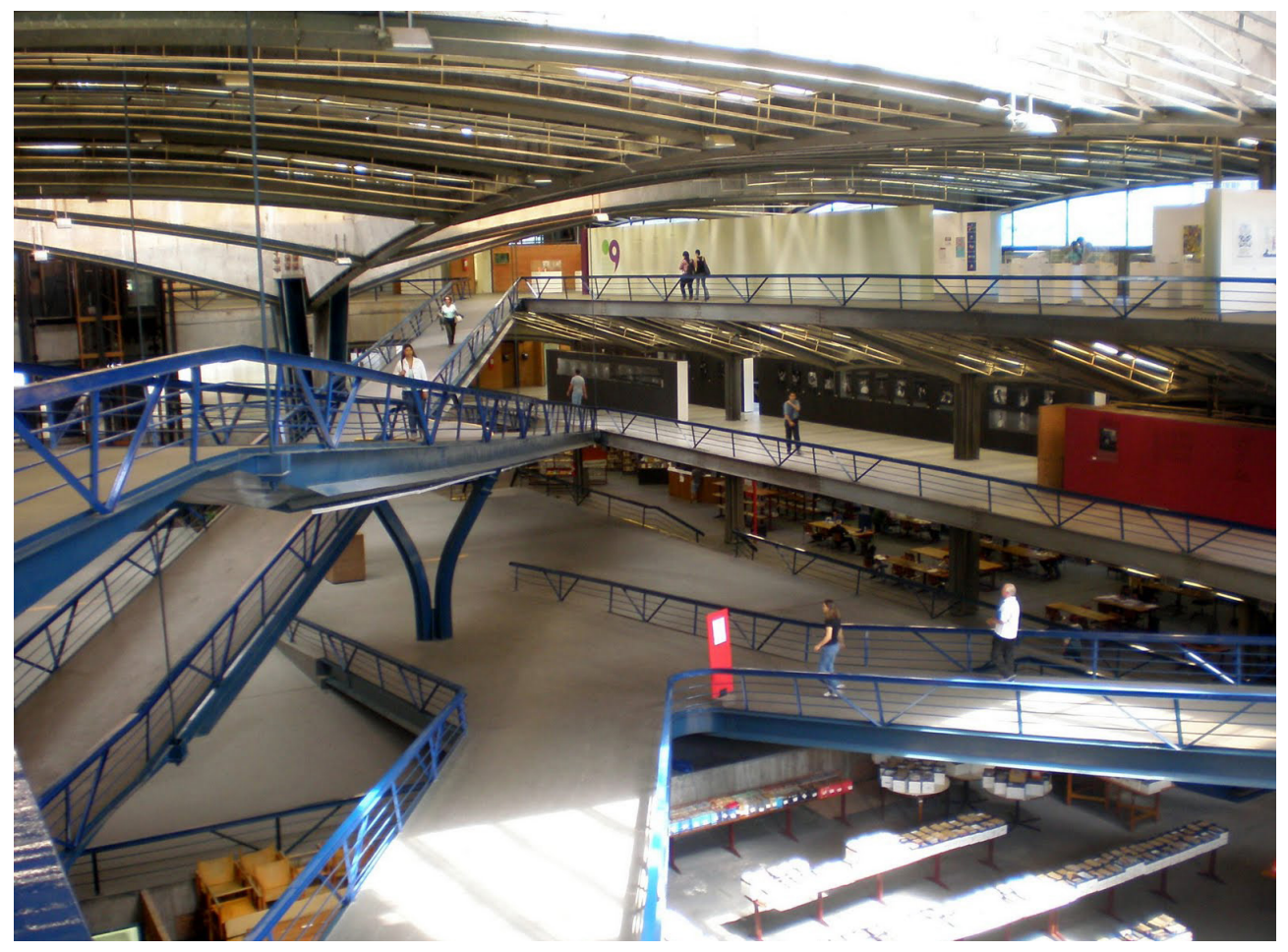

fig. 91 - Centro Cultural São Paulo. Edifício que opera com a lógica das continuidades e transposições, promovendo uma indistinção entre interior e exterior. Além da generosidade dos espaços que promove intensa participação e apropriação por parte dos frequentadores. Fonte: do autor. 
processo de atuação de modo mais amplo.

Nesse sentido a plataforma rodoviária de Brasília torna-se um exemplo de projeto em grande escala em que se realiza uma experiência urbana predecessora de algumas reivindicações e proposições disciplinares contemporâneas.

É possivel também inserir a plataforma de Lucio Costa no início de uma linhagem de propostas de intervenção urbana através do projeto de grandes estruturas com múltiplos usos, em geral associadas a sistemas infraestruturais, como mostrado no conjunto de imagens ao lado [figs. 84 a 91]. Embora em muitos aspectos as formulações de Banham [1975] a respeito das megaestruturas - como a expressividade formal tecnológica dos projetos da época retratada - se revelem datadas, há um ressurgimento de propostas que tratam a grande escala dos edifícios e a multiplicidade de usos como forma de atuação em ambientes urbanos. De Rem Koolhaas, em Bigness [Koolhaas, 1995], a Kenneth Frampton, em Megaform as urban landscape [2011] diferentes aproximações ao tema tem sido frequentes. É relevante portanto identificar os elementos constituíntes de um projeto inaugural dessa natureza, como a plataforma, e apontar para os instrumentos e dispositivos analisados nos capítulos anteriores como forma de intervenção possível em ambientes urbanos contemporâneos, no sentido de promover o incremento do grau de urbanidade através do desenho. 


\section{bibliografia}

ÁBALOS, I. (ed.)

2009. Naturaleza y artificio - El ideal pintoresco en la arquitectura y el paisajismo contemporáneo. Barcelona: Gustavo Gili.

AGUIAR, Douglas

2012. "Urbanidade e a qualidade da cidade". Arquitextos, 141.08, Vitruvius.

ALLEN, Stan

2009. "Del objeto al campo: condiciones de campo en la arquitectura y el urbanismo", in: Ábalos, I. (ed.), Naturaleza y artificio - el ideal pintoresco en la arquitectura y el paisajismo contemporáneo. Barcelona: Gustavo Gili.

ALLen, Stan \& MCQuAde, Marc (eds.).

2011. Landform Building: Architecture's New Terrain. Baden: Lars Müller Publishers.

BALLON, H. \& JACKSON, K.,

2007. Robert Moses and the Modern City: The Transformation of New York. Nova York: W. W. Norton.

BANHAM, Reyner

[1976] 1978. Megaestructuras, futuro urbano del passado reciente, Barcelona: Gustavo Gili.

[1971] 2009. Los Angeles, The Architecture of Four Ecologies. Los Angele: University of California Press.

BARTHES, Roland.

[1980] 1984. A câmara clara. Rio de Janeiro: Nova Fronteira, 1984. 
BOIS, Y.-A.

2009. "Paseo pintoresco alrededor de Clara-Clara", in: Ábalos, I. (ed.), Naturaleza Y Artificio - El Ideal Pintoresco En La Arquitectura Y El Paisajismo Contemporáneo. Barcelona: Gustavo Gili.

BRAGA, Milton

1999. O concurso de Brasília: Os sete projetos premiados. Dissertação de Mestrado, Depto de Arquitetura e Urbanismo, Universidade de São Paulo.

2006. Infra-estrutura e projeto urbano. Tese de Doutorado, Depto de Arquitetura e Urbanismo, Universidade de São Paulo.

2010. O concurso de Brasília: sete projetos para uma capital. São Paulo: Cosac Naify.

Branco, Maria Cecília C. C.

2006. Brasília: narrativas urbanas. Dissertação de Mestrado, Programa de Pós-Graduação em Sociologia, Universidade de Brasília. Brasília: s.n.

Buccl, Ângelo

1998. Anhangabaú, o Chá e a metrópole. Dissertação de Mestrado, Depto de Arquitetura e Urbanismo, Universidade de São Paulo.

CHOAY, F.; MACHADO, L. V.

2006. A alegoria do patrimônio. São Paulo: Estação Liberdade/Unesp.

COSTA, Lucio

1995. Lucio Costa: Registro de uma vivência. São Paulo: Empresa das Artes.

DE SOLA-MORALES, I.

2004. Diferencias. topografía de la arquitectura contemporánea. Barcelona: Gustavo Gili.

DE SOUZA ROCHA, R.

2007. A arquitetura moderna diante da esfinge ou a nova monumentalidade-uma análise do monumento nacional aos mortos na Segunda Guerra Mundial, Rio de Janeiro. Anais do Museu Paulista, v. 15, n. 2. 
FRAMPTON, Kenneth

2011. "Megaform as Urban Landscape", in: Allen, Stan \& Mcquade, Marc (eds.). Landform Building: Architecture's New Terrain. Baden: Lars Müller Publishers.

1999. Megaform As Urban Landscape. University of Michigan

FRIEDMAN, Yona

2006. Pro Domo. Barcelona: ACTAR.

2009. Interview. Blue Print, June. London.

GANDELSONAS, M.

1973. "Linguistics in Architecture". Casabella, v. 374, n. p. 22.

GELL, Alfred

1998. Art and Agency: an Anthropological Theory. Oxford New York: Clarendon Press Oxford University Press.

GOROVITZ, M.

1985. Brasília uma questão de escala. São Paulo, Projeto.

Gregotti, VitTORIO

2008. "Território e arquitetura", in: NESBITT, K. Uma nova agenda para a arquitetura. São Paulo: Cosac Naify.

GUATELLI, Igor.

2006. "A marquise do Parque lbirapuera e manifPlataforma do conceito derridiano "entre": arquitetura como suporte de ações". Vitruvius [http://www. vitruvius.com.br/arquitextos/arq000/esp359.asp].

HAYS, K. M.

2000. Architecture Theory Since 1968. Cambridge Ms/London: Mit Press.

HOLANDA, Frederico de

2008. "Brasília - proposta, presente, desejo". Seminário de história da cidade e do urbanismo, v. 10, n. 3.

2010. Urbanidade arquitetônica e social. Simpósio Temático:

Urbanidade(s) do I Enanparq, rio 
IWAMIZU, Cesar Shundi

2008. A Plataforma Rodoviária de Jaú e a dimensão urbana da arquitetura. Dissertação de Mestrado, Depto de Arquitetura e Urbanismo, Universidade de São Paulo.

JOHNSTON, Pamela

2005. Architecture is Not Made With the Brain : the Labour of Alison and Peter Smithson. London: Architectural Association.

KOOLHAAS, Rem \& Hans U. OBRIST.

2011. Project Japan: Metabolism Talks... Colônia: Taschen.

KOOLHAAS, Rem

1995. S, M, L, XL. New York: Monacelli Press.

KRAUSS, R.; Bois, Y.-A.

1997. Formless, A User's Guide. New York: Zone Books.

KWINTER, S.

1986. La Cittá Nuova: Modernity and Continuity. New York: Zone Books.

LATOUR, Bruno

2005. Making Things Public: Atmospheres of Democracy. Cambridge, Mass [Karlsruhe, Germany]: MIT Press ZKM/Center for Art and Media in Karlsruhe.

2005. Reassembling the Social: an Introduction to Actor-Network-Theory. Oxford. New York: Oxford University Press.

LE CORBUSIER, 2004 [1930]. Precisões sobre um estado presente da arquitetura e do urbanismo. São Paulo: Cosac Naify.

LEY, Sabrina van der, AND RICHTER, Markus

2008. Megastructure Reloaded : Visionary Architecture and Urban Design of the Sixties Reflected By Contemporary Artists. Ostfildern: Hatje Cantz. 
MONSTAFAVI, Mohsen \& Gareth DOHERTY (ed.)

2010. Ecological Urbanism. Baden: Lars Muller Publishers.

MELLO E FRANCO, Fernando de

2005. A construção do caminho: A estruturação da metrópole através da conformação técnica da Bacia de São Paulo. Tese de Doutorado, Depto de Arquitetura e Urbanismo, Universidade de São Paulo.

MOTTA, FILHO, Geraldo, E WISNIK, Guilherme

2003. O Risco : [Lucio Costa E a Utopia Moderna. Rio de Janeiro, Brasil: Bang Bang Filmes Produções.

MUMFORD, L.

1961. The City in History: Its Origins, Its Transformations, and Its Prospects. Mariner Books.

1997. The Culture of Cities. New York/ London: Routledge.

MUNIZ, Cristiane

2005. A cidade e os trilhos: o metro de São Paulo como desenho urbano Dissertação de Mestrado, Depto de Arquitetura e Urbanismo, Universidade de São Paulo.

NOBRE, Ana Luiza

2004. Um modo de ser moderno: Lucio Costa e a crítica contemporânea. São Paulo: Cosac Naify.

REISER \& UMEMOTO

[2006] 2010. "Introduction", in: Kristas Sykes, A. (ed.). Constructing a New Agenda: Architectural Theory 1993-2009. Nova York: Princeton Architectural Press.

RODRIGUES FIGUEIREDO, Cleber

2006. Pesquisa, estudo e reflexão sobre a Rodoviária do Plano Piloto, Trabalho Final de Graduação, UnB.

Rossl, A.

2001. A arquitetura da cidade. São Paulo: Martins Fontes. 
SANTOS, Milton

2007. Encontros. Org. Maria Angela Peleite. Rio de Janeiro: Beco do Azougue.

Senado federal. I Seminário de Estudos dos Problemas Urbanos de Brasília. Brasília: Senado Federal, 1974.

SERT, J. L.; LÉGER, F.; GIEDION, S.

1943. Nine Points on Monumentality. Architecture Culture, v. 1968, n. p. 29-30.

SMITHSON, Alison, and Peter

1973. Without Rhetoric; an Architectural Aesthetic, 1955-1972. [London]: Latimer New Dimensions.

2005. The Charged Void--Urbanism. New York, N.Y: Monacelli Press.

SOLA-MORALES, Manuel

2006. De cosas urbanas. Barcelona: Gustavo Gili.

STRATHERN, Marilyn

1989. "The Concept of Society is Theoretically Obsolet", in Ingold, T. (ed.) Key debates in Anthropology. INGOLD, Tim (ed.). London:

Routledge.

TENORIO, Gabriela de Souza

2008. "... e Brasília tem centro?”, comunicação apresentada no X Seminário de história da cidade e do urbanismo - Anais (cd-ROM). Recife: Centro de estudos avançados de conservação integrada - CECl.

TELLES, Sophia

1998. Arquitetura moderna no brasil: o desenho da superfície. São

Paulo: Dissertação de Mestrado, Universidade de São Paulo.

[1989] 2010. "Lucio Costa: monumentalidade e intimismo", in Textos fundamentais sobre história da arquitetura moderna brasileira_parte 1. São Paulo: Romano Guerra.

VARNELIS, KazyS

2008. The Infrastructural City : Networked Ecologies in Los Angeles. Bar- 
celona ; New York [Los Angeles] [New York]: Actar The Los Angeles Forum for Architecture and Urban Design The Network Architecture Lab, Graduate School of Architecture, Planning and Preservation, Columbia University.

WALDHEIM, Charles (ed.)

2006. The Landscape Urbanism Reader. New York: Princeton Architecture Press.

WESELY, Michael \& Lina KIM

2010. Arquivo Brasília. Cosac Naify, São Paulo.

WISNIK, Guilherme

2001. Lucio Costa. São Paulo, SP, Brasil: Cosac \& Naify Edições.

2009. Estado Crítico, à deriva nas cidades. São Paulo, Brasil: Publifolha.

ZAERA POLO, Alejandro

2008. "The Politics of the Envelope". Log \#13/14 e \#16. NY: Anyone Corp.

\section{Periódicos}

Acrópole, Número especial dedicado a Brasilia 375-376, julho-agosto de 1970.

Acrópole, Número especial dedicado a Brasília 256-257, abril de 1960, 2a Edição [1970].

Atas do Congresso Internacional Extraordinário De Críticos De Arte. 1959, Brasília, São Paulo, Rio de Janeiro. Anais. Brasília, São Paulo, Rio de Janeiro: 1959.

Brasilia, número 30, Ano 3, junho de 1959.

Brasília, número 45-48, Ano 4, setembro a dezembro de 1960.

Brasília, número 50-52, Ano 5, fevereiro a abril de 1961 [comemorativa 
de 1 ano]

Módulo, Volume 3, número 14, agosto de 1959, Rio de Janeiro.

\section{Publicações eletrônicas}

Rossetti, Eduardo Pierrotti. Lucio Costa e a Plataforma Rodoviária de Brasilia. Arquitextos, São Paulo, 10.119, Vitruvius, abr $2010<$ http://www. vitruvius.com.br/revistas/read/arquitextos/10.119/3371>. 
